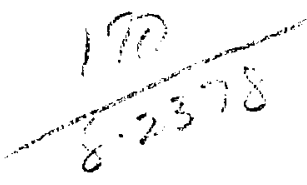

\title{
IO":-SELECTIVE ELECTRODES IN ORGANIC ELEMENTAL AND FUNCTIONAL GROUP ANALYSIS: A REVIEW
}

W. Selig

November 8, 1977

Work performed under the auspices of the US. Department of Energy by the UCLLL under contract number W-7405-ENG-48

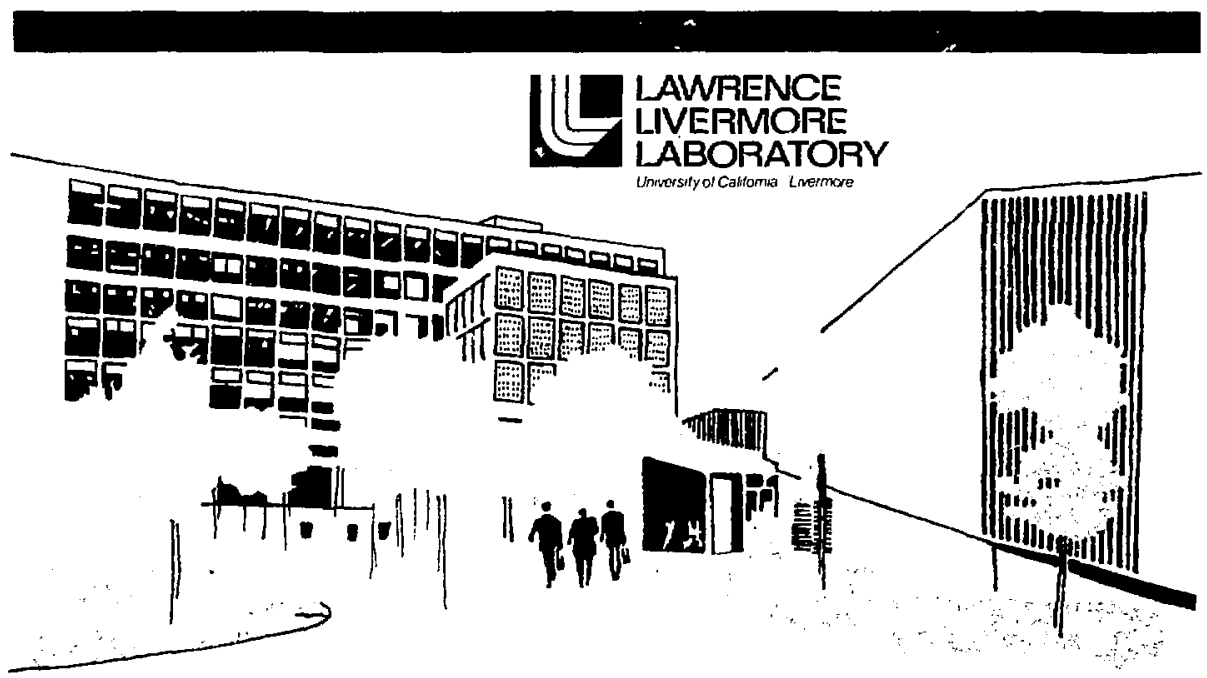




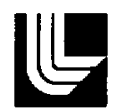

\title{
LAWRENCE LIVERMORE LABORATORY
}

University of Cahtornia Livermore, Califomia, 94550

UCRL-52393

\section{ION-SELECTIVE ELECTRODES IN ORGANIC ELEMENTAL AND FUNCTIONAL GROUP ANALYSIS: A REVIEW}

\author{
W. Selig
}

MS. date: November 8, 1977

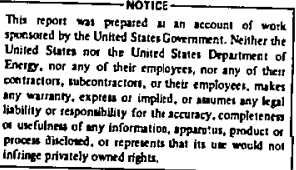




\section{CONTENTS}

Abstract

Introduction

References

Elementa1 Analysis

Antons

Fluorine

References

Sulfur

Determination as Sulfate

Determination as Sulfide

References.

Halogens

References

Phosphorus and Arsenic

References.

Boron as Tetrafluoroborate

References

Organic Anions

References.

Meta1s

References

Nitrogen as Ammonium Ion

References

Organic Cations

References

Surfactants and Detergents

References .

Functional Group Analysis

Divalent Sulfur Functions

Thiols

Disulfides 
Mercaptopyrimidines

Xanthates

Carbon Disulfide

References

Epoxides

References

Hydroxyl groups

Hydroxy1 in Polymers

Vicinal Glycols

Carbohydrates .

Formaldehyde

Primary Amino Groups

Carboxylic Acids in the Presence of Acyl Chloride

Cyanamide

p-Urazine

References

Physiologically Active Compounds

Chymotrypsin

Cyanogenic Glycosides

Cyanocobalamine

Choline Esters

Ephedrine and Methylephedrine

Saccharin

Vitamins

Proteins

Miscellaneous

Colloid Titration

Miscellaneous Drugs .

1-Fluoro-2, 4-Dinitrobenzene

References

Ion-Selective Electrodes as Detectors in Chromatography

Gas-Chrcmatography

\section{Liquid-Chromatography}

References.

Acknowledgments 


\section{ION-SELECTIVE ELECTRODES IN ORGANIC ELEMENTAL AND FUNCTIONAL GROUP ANALYSIS: A REVIEW}

\section{ABSTRACT}

The literature on the use of lon-selective electrodes in organfc elemental and functional group analysis is surveyed in some detall. The survey is complete through Chemical Abstracts, Vol. 83 (1975).

\section{INTRODUCTION}

Since the development of the fluoride Ion-selective electrode (ISE) in $1966,{ }^{1}$ the number of papers dealing with the theory and applications of ISE's has increased every year at a nearly exponential rate. Most of the applications have been in the field of Inorganic analysis. There have, however, been some appllcations of ISE's to organic elemental and functional group analysis. These applications have as yet not been incorporated into the newer texts dealing with organic analysis, but some may be found in the reviews. 2-9 In this review, methods using ISE's in organic elemental and functional group analysis are collected, whlle methods using enzyme electrodes are not included. Some suggestions for further applications are made that, in some instances, w11 be rather obvious to the user.
The use of $\mathrm{ISE}^{\prime} \mathrm{s}$ as detectors in gas chromatography is also described.

The techniques commonly used with ISE's may be classified as direct potentiometric measurement, based on the Nernstian logarithmic relationship between electromotive force (emf) and activity, and potentiometric titration, which is usually more accurate and precise (but at the cost of increased time and difficulty).

A serious problem in both techriques is the slow establis\} ant of equilibrium potentials. In foientometric titrations, especially, this is found near the endpoint of the titration. It is, therefore, advantageous to use an automatic titrator capable of delivering the titrant at a slow a:d constant rate. Also, to minlmize possible errors, standardization of the titrant and determination 
of the sample should be performed in nearly Identical fashions.

In direct enf measurement, establishing equilibrium emf is slow, especially at very low concentrations. One solution to this problem may be the use of the recently introduced time-response paper. ${ }^{10}$ According to Warner and Bressan, ${ }^{11}$ drifting emf's show a changing activity at the interface, which is most frequently due to the mixing of contaminants froin various sources. According to these workers, dirty beakers and electrode surfaces are a subtle and very persistent cause of an apparent inabllity to reach low-level emf's. Given a clean beaker and clean electrodes, an electrode equilibrated at
$10^{-3} \mathrm{M}$ of sodium fluoride $(-5 \mathrm{mV})$ and then inserted into dist11led water containing $0.28 \mathrm{ppb}$ of fluoride w111 register the following emf's at the given times w1th two water changes:

$\begin{array}{cc}\text { Time - min } & \frac{\text { Emf }-\mathrm{mV}}{200} \\ 2 & +200 \\ 20 & +237 \\ 45 & +244(=1.7 \mathrm{ppb})\end{array}$

In this review, the literature is surveyed in some detail to present a critical choice to the potential user. Readers will also want to consult the recent study by Baiulescu and Cosofret. ${ }^{12}$ This 1iterature survey is complete through Chemical Abstracts 83, (1975). Addenda to this review w111 be issued biennially.

\section{References}

1. M. S. Frant and J. W. Ross, Jr., Science, 154, 1553 (1966).

2. K. Camman, Naturwiss, 57, 298 (1970).

3. W. Simon, H. Wuhrmann, M. Vasak, L. A. R. Ploda, R. Dohner, and Z. Stefanac, Angew. Chem., 82, 433 (1970).

4. E. C. Toren Jr., and R. P. Buck, AnaZ. Chem., 42, 284R (1970).

5. R. P. Buck, Anal. Chem., 44 270R (1972).

6. R. P. Buck, Anal. Chem., 46, 28R (1974).

7. N. Ishibash1, Kagaku No. Ryoiki, 29, 153 (1975); through Chem. Abstr., 83, 187999m (1975).

8. K. Toth and E. Pungor, Hung. Sci. Instrum., 25, 15 (1972); through Chem. Abetr., 78, 143572j (1973).

9. J. Koryta, Analyt. Chim. Acta, 61, 320 (1972).

10. Orion Research, Inc. Newsitetter, 3, 8 (1971).

11. T. B. Warner and D. J. Bressan, Analyt. Chim. Acta, 63, 165 (1973).

12. G. E. Balulescu and V. V. Cosofret, Applications of Ion-Selective Membrane Electrodes in Organic Analysis (Halsted Press, New York, 1977). 


\section{ELEMENTAL ANALYSIS}

\section{Anions}

\section{Fuorime}

A thorough discussion of the analysis of fluorine in organic compounds is given in Ma's monograph. ${ }^{1}$ As recent1y as 1965 MacDonald, ${ }^{2}$ in a review of organic microanalytical methods, was unable to recommend any particular method as distinctly preferable to others for fluorine and stated that "In the analysis for fluorine, faith in one's method seems to be as important as scientific rectitude." It is thus commonly accepted that fluorine is one of the most difficult elements to determine in organic compounds, particularly on the microscale. The thorium nitrate titration has been the most popular method of determining fluoride. Papers dealing with this method still continue to appear, ${ }^{3}$ but the method has its 1Imftations.

The separation of interfering lons (of particular interest in organic analysis are sulfate and phosphate) is usually accomplished by the Willard-Winter distillation ${ }^{4}$ in which fluoride is separated as fluosilicic acid. The distillation procedure, however, is rather time-consuning and often ylelds inaccurate results.

A second group of methads for eliminating interference in fluorine ana1- ysis is ion-exchange. These methods, up to 1961 , are summarized in Horton's $s^{5,6}$ monographs.

f third group may be termed "chemical methods." For the separation of sulfate, some of the methods are precipitation by benzidine, ${ }^{7}$ separation as silver sulfate, ${ }^{3}$ and precipitation with cadmium and mercuric nitrate. ${ }^{9}$ For the separation of phosphate, precipitation as sijver phosphate ${ }^{10,11}$ or with cadmium and mercuric nitrate, ${ }^{9}$ and adsorption by either zinc carbonate ${ }^{12}$ or zinc oxide $^{13}$ have been suggested. Most of these methods, however, requile at least one filtration step and thus are time-consuming.

Horton ${ }^{6}$ has invited efforts toward the direct determination of fluoride without separation. We believe that, with the advent of the fluoride ISE, this goal is now in sight. The usefulness of this electrode in chemical analysis and in kinetic studies is evident from the number of papers citIng it that have appeared since 1967.

More papers have appeared on the analysis of fluorine in organic compounds than for any other element. This applies also to the use of ISE's in the analysis of organic compounds. The first paper, by Light and Mannion, ${ }^{14}$ appeared in 1969. The 
electrodes required for this determination are a fluoride Ion-selective Indicator electrode (Orion 94-09 or equivalent) and a single-junction raference electrode (Orton 90-01, with Orion 90-00-01 filling solution, or equivalent).

Light and Mannion ${ }^{14}$ recommended combustion of the organic sample in an oxygen-flask made of polycarbonate (Nalgene No. 4103). It has previously been confirmed that results obtained with quartz flasks are more accurate than those with borosilicate flasks. 2 Since, however, quartz flasks are quite expensive, the use of plastic flasks offers a distinct advantage. It is necessary to rotate the flask during combustion to keep the flame from scorching the walls. Light and Mannion found it necessary to use dodecyl alcohol as a combustion accelerator, since low results were obtained otherwise. The combustion products were adsorbed in water. The titrant was $0.005 \mathrm{M}$ thorium nitrate in 80\% ethanol; the titration medium consisted of $80 \%$ ethanol adjusted to $0.01 \mathrm{M}$ in nitric acid. Titrations were carried out to a potential (which is the point of maximum inflection) that had been predetermined by titratIon of a standard under Identical conditions. The results of a variety of organic compounds ranging in fluorine content from 13 to $76 \%$ are shown in Table 1. Por samples in the range of 1 to $10 \mathrm{mg}$ the results were within $\pm 0.3 \%$; the standard deviation of the absolute exror was $0.20 \%$.

For the determination of microamounts of fluortde, the aicoholic medium suggest by Lingane ${ }^{15,16}$ was advantageous, since the solubility of the rare earth fluorides is considerabiy reduced, thus enhancing the endpoint breaks. Light and Mannion, in contrast to Lingane, found that thorIum was a somewhat more sensitive titrant than lanthanum, yielding a larger endpoint break (Fig. 1). This, however, may be due to the differences in the two systems (Lingane's is neutral and unbuffered in $70 \%$ ethanol, while Light and Mannion's is $0.01 \mathrm{M}$ in nitric acid and $80 \%$ ethanol). A $0.01 \mathrm{M}$ nitric acid solution was recommended by these workers, since the

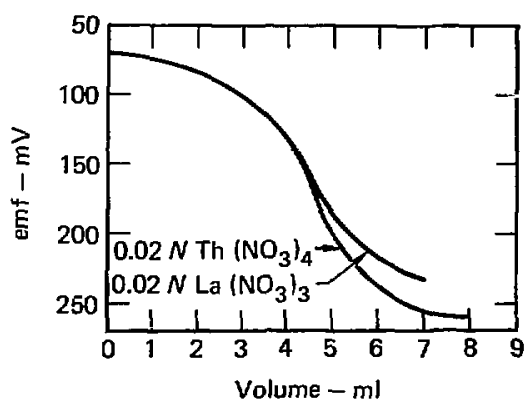

FIg. 1. Titration of fluoride with thorlum and lanthanum in $0.01 M$ nitric acid (2 mg $\mathrm{F}$ using fluoride electrode, $80 \%$ ethanoi). Source: Ref. 14, used with permission. 
Table 1. Determination of fluorine In organic compounds following combustion in a polycarbonate flask. ${ }^{a}$

\begin{tabular}{|c|c|c|c|c|}
\hline & & & Ine cont & \\
\hline Sample & $\begin{array}{c}\text { Weight, } \\
\text { mg }\end{array}$ & $\begin{array}{c}\text { Theory, } \\
7\end{array}$ & $\begin{array}{c}\text { Found, } \\
\%\end{array}$ & $\begin{array}{c}\text { Error, } \\
\quad z\end{array}$ \\
\hline p-Fluorobenzolc acid ${ }^{b}$ & $\begin{array}{l}6.616 \\
6.008 \\
8.626 \\
8.700\end{array}$ & 13.56 & $\begin{array}{l}13.74 \\
13.82 \\
13.81 \\
13.69\end{array}$ & $\begin{array}{l}+0.18 \\
+0.26 \\
+0.25 \\
+0.13\end{array}$ \\
\hline Trifluoroacetanilide & $\begin{array}{l}7.926 \\
6.822 \\
7.508 \\
8.414\end{array}$ & 30.14 & $\begin{array}{l}30.15 \\
30.20 \\
30.21 \\
30.10\end{array}$ & $\begin{array}{l}+0.01 \\
+0.06 \\
+0.07 \\
-0.04\end{array}$ \\
\hline p-Fluoxobenzonltrile $e^{c}$ & $\begin{array}{l}7.108 \\
9.498 \\
6.806 \\
8.752\end{array}$ & 15.69 & $\begin{array}{l}15.79 \\
15.32 \\
15.66 \\
15.61\end{array}$ & $\begin{array}{l}+0.10 \\
-0.37 \\
-0.03 \\
-0.08\end{array}$ \\
\hline $\begin{array}{l}\text { Polytetra- } \\
\text { fluoroethylene }\end{array}$ & $\begin{array}{l}2.420 \\
3.204 \\
3.344 \\
3.688\end{array}$ & 76.00 & $\begin{array}{l}76.28 \\
75.59 \\
75.75 \\
75.98\end{array}$ & $\begin{array}{l}+0.28 \\
-0.41 \\
-0.25 \\
-0.02\end{array}$ \\
\hline o-Fluorotoluene $e^{c}$ & $\begin{array}{l}5.704 \\
5.772 \\
9.730\end{array}$ & 17.25 & $\begin{array}{l}16.94 \\
16.99 \\
17.26\end{array}$ & $\begin{array}{l}-0.31 \\
-0.26 \\
+0.01\end{array}$ \\
\hline $\mathrm{C}_{6} \mathrm{H}_{5} \mathrm{CF}=\mathrm{CH}_{2} \mathrm{C}_{6} \mathrm{H}_{5}^{\mathrm{d}}$ & $\begin{array}{l}9.118 \\
8.932 \\
7.804\end{array}$ & 9.60 & $\begin{array}{l}9.50 \\
9.37 \\
9.55\end{array}$ & $\begin{array}{l}-0.10 \\
-0.23 \\
-0.05\end{array}$ \\
\hline $\mathrm{C}_{6} \mathrm{H}_{5} \mathrm{CF}_{2} \mathrm{CH}_{2} \mathrm{C}_{6} \mathrm{H}_{5}{ }^{\mathrm{d}}$ & $\begin{array}{l}7.860 \\
6.660 \\
7.304\end{array}$ & 17.43 & $\begin{array}{l}17.19 \\
17.19 \\
17.33\end{array}$ & $\begin{array}{l}-0.24 \\
-0.24 \\
-0.10\end{array}$ \\
\hline
\end{tabular}

Dodecyl Alcohol used as a combustion ald.

$\mathrm{b}_{\text {BDH microchemical standards. }}$

Purffied compounds.

dExperimental research compounds.

hydrolysis of the titrant at lower acidities was a problem, as shown in Fig. 2.

The constituents usually found in organic compounds, surh as nitrogen and halogens, did not interfere in this analysis. Sulfate and phosphate form Insoluble salts with thorfum and are known to interfere. ${ }^{2}$ Their effect was not Investigated by light and Mannion. Selig ${ }^{17}$ decomposed organic samples by combustion in a Vycor (Corning 


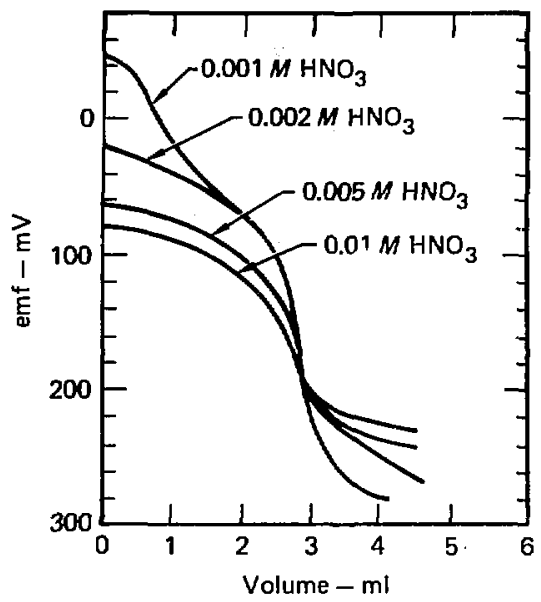

Fig. 2. Titration of fluoride with thorium at various acidities ( $1 \mathrm{mg} \mathrm{F}$ using fluoride electrode, $80 \%$ ethanoI; $0.005 \mathrm{M}$ Th $\left.\left(\mathrm{NO}_{3}\right)_{4}\right)$. Source: Ref. 14, used with permission.

Glass Works, $>96 \%$ silica) oxygen-flask provided with suitable vycor joints. No combustion accelerator was found necessary. The combustion products were absorbed in $0.1 M$ sodium hydroxide. Carbon dioxide interfered and was removed after acidification to pH 4.4 by boiling. The titrant was $0.02 \mathrm{M}$ Ianthanum nitrate; the titration medium was an aqueous solution adjusted to $\mathrm{pH} 5$ to 7 with dilute sodium hydroxide. In five compounds varying in fluorine content from 12 to $76 \%$, the absolute error was less than 0.3\%; the standara deviation of the absolute error was $0.06 \%$. The results are shown in Table 2 .
In the presence of up to a threefold excess of sulfate, a positive bias amounting to 1 to $1.6 \%$ of fluorine was found. This interference was eliminated by the addition of a slight excess of barlum nitrate. Filtration of the resulting barium sulfate was unnecessary. However, in Its presence, equflibrium potentlals were established at a slightly slower rate and the endpoint breaks were somewhat suppressed, as shown in Fig. 3. Results for the analysis of fluorine in sulfur-containing organic compounds are shown in Table 3 . The fluorine content of the compounds analyzed varied from 7 to $11 \%$, the sulfur content from 9 to $25 \%$, and the silfur-to-fluorine ratio from 0.8 to 3.4. The standard deviation of the absolute error was $0.04 \%$.

Attempts to determine fluoride in the presence of sulfate in $80 \%$ ethano1 and $0.01 M$ nitric acid (suggested by Light and Mannion) with lanthanum nitrate failed. Attempts to determine fluoride in the presence of equimolar amounts of phosphate also fafled. In this determination, therefore, phos... phate must be removed prior to the fluoride analysis.

Selig ${ }^{17}$ found that the acidic medium used by LIght and Mannion decreased the sensitivity of the titration considerably, although it reduces the degree of hydrolysis of the titrant. According to Lingane, 
Table 2. Determination of fluorine in organic compounds.

\begin{tabular}{|c|c|c|c|c|}
\hline \multirow[b]{2}{*}{ Sample } & \multirow[b]{2}{*}{$\begin{array}{c}\text { We1ght, } \\
\text { mg }\end{array}$} & \multicolumn{2}{|c|}{ Fluortne content } & nt \\
\hline & & $\begin{array}{c}\text { Theory, } \\
\%\end{array}$ & $\begin{array}{c}\text { Found, } \\
\%\end{array}$ & $\begin{array}{c}\text { Error, } \\
\%\end{array}$ \\
\hline $\mathrm{p}$-Fluorobenzolc actd $\mathrm{a}^{\mathrm{a}}$ & $\begin{array}{l}18.30 \\
18.60 \\
18.60 \\
15.75 \\
20.65\end{array}$ & 13.56 & $\begin{array}{l}13.67 \\
13.56 \\
13.48 \\
13.66 \\
13.41\end{array}$ & $\begin{array}{r}+0.11 \\
0.00 \\
-0.08 \\
+0.10 \\
-0.15\end{array}$ \\
\hline $\operatorname{Tr} 1$ fluoracetan $111 d e^{a}$ & $\begin{array}{l}7.10 \\
8.45 \\
8.45 \\
7.90\end{array}$ & 30.14 & $\begin{array}{l}37.12 \\
30.21 \\
30.09 \\
29.96\end{array}$ & $\begin{array}{l}-0.02 \\
+0.07 \\
-0.05 \\
-0.16\end{array}$ \\
\hline $\begin{array}{l}\text { m-Trifluoromethyl- } \\
\text { benzolc acid }\end{array}$ & $\begin{array}{r}10.30 \\
12.45 \\
9.50 \\
9.05\end{array}$ & 29.98 & $\begin{array}{l}29.86 \\
29.94 \\
29.95 \\
30.15\end{array}$ & $\begin{array}{l}-0.12 \text { with decalin } \\
-0.04 \text { with decalin } \\
-0.03 \\
+0.17\end{array}$ \\
\hline $\begin{array}{l}\text { Bis }(2,2-\text {-initro-2- } \\
\text { fluoroethyl) forma } 1 \\
\text { (FEFO) }\end{array}$ & $\begin{array}{l}30.70 \\
29.15 \\
22.80 \\
22.30 \\
20.80 \\
24.30\end{array}$ & 11.87 & $\begin{array}{l}11.92 \\
11.93 \\
11.34 \\
11.89 \\
11.91 \\
11.86\end{array}$ & $\begin{array}{l}+0.05 \\
+0.06 \\
+0.0 ? \\
+0.02 \\
+0.04 \\
-0.01\end{array}$ \\
\hline $\begin{array}{l}\text { Polytetrafluoro- } \\
\text { ethylene }\end{array}$ & $\begin{array}{l}3.825 \\
2.911 \\
3.097 \\
2.512\end{array}$ & 75.98 & $\begin{array}{l}75.72 \\
76.05 \\
75.95 \\
76.02\end{array}$ & $\begin{array}{l}-0.26 \\
+0.09 \\
-0.03 \\
+0.04\end{array}$ \\
\hline
\end{tabular}

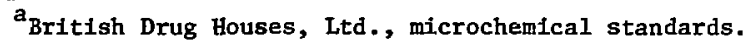

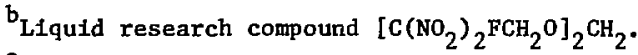

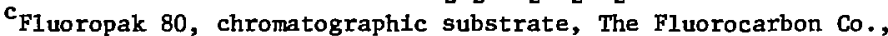
Fullerton, Calif.

however, this hy rolysis is legs pronounced with lanthanum than with thorlum. At pH 6 only a single inflection was found in the titration curve, as shown in Fig. 4. There is thus no evidence of hydrolysis. In $80 \%$ ethanol and $0.01 M$ nitric acid the endpoint breaks were considerably smaller than in the aqueous medium at $\mathrm{pH} 5$ to 7. Moreover, the speed of the manual titration in the aqueous medium was faster by a factor of approximately 3 over that in the alcoholic medium. A drawback in Selig's procedure is the fact that recovery of fluoride is not strictly 


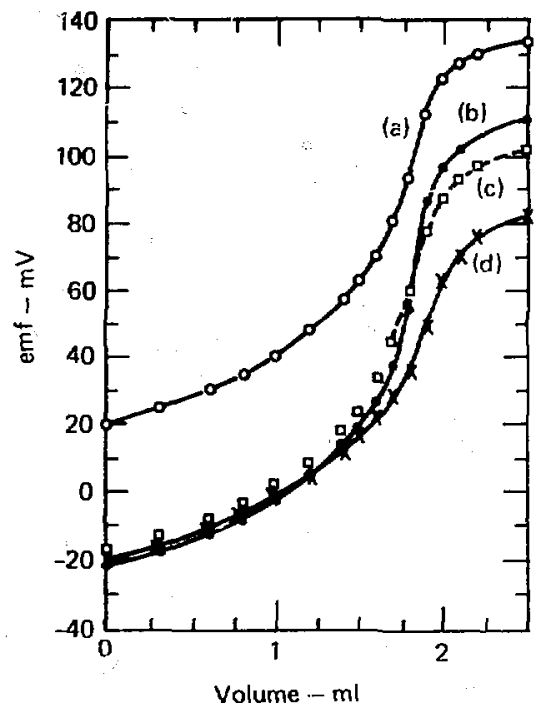

Fig. 3. Potentiometric titration of $2.28 \mathrm{mg}$ fluoride with $0.02 \mathrm{M}$ La(III). Comparison of aqueous medium at $\mathrm{pH} 6$ with $80 \%$ ethanolic medium, $0.01 \mathrm{M}$ nitric acid, and effect of added sulfate. (a) $80 \%$ ethanol, $0.01 \mathrm{M}$ nitric acid. (b) Aqueous medium, $\mathrm{pH}$ 6. (c) Aqueous medium, $\mathrm{pH} 6$, $10 \mathrm{mg}$ sulfate and slight excess of barium nitrate added. (d) Aqueous meaizu, pH 6, $5 \mathrm{mg}$ sulfate added. Source: Ref. 17, used with permission.

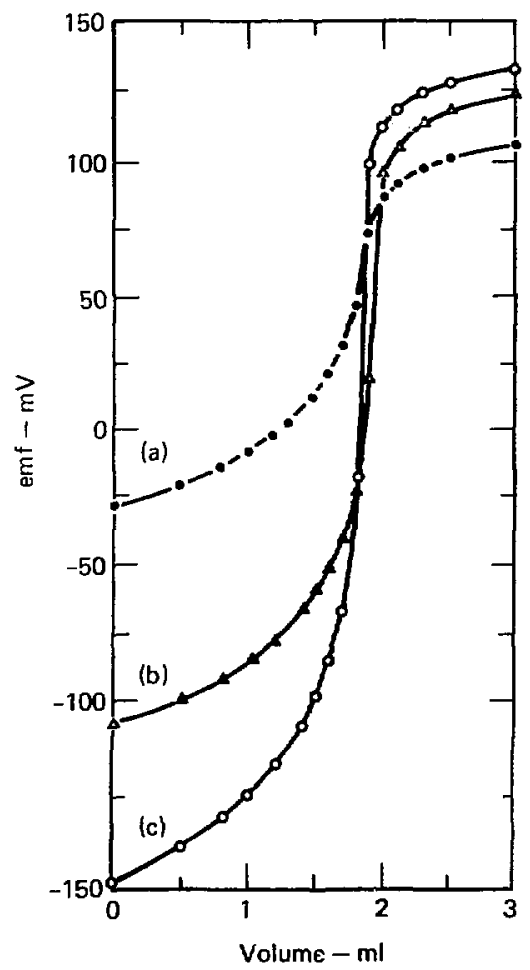

Fig. 4. Potentiometrle titration of $2.28 \mathrm{mg}$ fluoride at $\mathrm{pH} 6 ; 0.02 \mathrm{M}$ lanthanum nitrate. (a) Water. (b) $60 \%$ ethano1. (c) $80 \%$ ethanol. Source: Ref. 17, used with permission. 
Table 3. Determination of fluorine in the presence of sulfur.

\begin{tabular}{|c|c|c|c|c|}
\hline \multirow[b]{2}{*}{ Sample } & \multirow[b]{2}{*}{$\begin{array}{c}\text { Weight, } \\
\text { mg }\end{array}$} & \multicolumn{2}{|c|}{ Fluorine content } & \\
\hline & & $\begin{array}{c}\text { Theory, } \\
\%\end{array}$ & $\begin{array}{c}\text { Foumd, } \\
\%\end{array}$ & $\begin{array}{c}\text { Error, } \\
\%\end{array}$ \\
\hline $\begin{array}{l}\text { p-Fluorosulfony } 1 \\
\text { benzenesulfony1 } \\
\text { chloride }\end{array}$ & $\begin{array}{l}33.40 \\
40.95 \\
39.60 \\
30.80 \\
41.80 \\
38.15 \\
33.55\end{array}$ & 7,34 & $\begin{array}{l}7.47 \\
7.56 \\
7.53 \\
7.25 \\
7.18 \\
7.28 \\
7.24\end{array}$ & $\begin{array}{l}+0.13 \text { no barium nitrate added } \\
+0.22 \text { no barium nitrate added } \\
+0.21 \text { no barium nitrate added } \\
-0.09 \\
-0.16 \\
-0.06 \\
-0.10\end{array}$ \\
\hline $\begin{array}{l}\text { 4-Fluoro-3-nitro- } \\
\text { phenylsulfone }\end{array}$ & $\begin{array}{l}24.75 \\
28.85 \\
29.05 \\
24.40\end{array}$ & 11.04 & $\begin{array}{r}0.95 \\
10.93 \\
10.95 \\
11.09\end{array}$ & $\begin{array}{l}-0.09 \\
-0.11 \\
-0.09 \\
+0.05\end{array}$ \\
\hline $\begin{array}{l}\text { 4-Fluorobenz ene- } \\
\text { sulfonamide }\end{array}$ & $\begin{array}{l}25.25 \\
25.75 \\
27.55 \\
29.45\end{array}$ & 10.84 & $\begin{array}{l}10.70 \\
10.87 \\
10.79 \\
10.79\end{array}$ & $\begin{array}{l}-0.16 \\
+0.03 \\
-0.05 \\
-0.05\end{array}$ \\
\hline
\end{tabular}

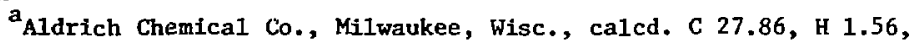
$\mathrm{C} 1 \mathrm{13.71}, \mathrm{S} / \mathrm{F}=3.38$; found $\mathrm{C} 27.86, \mathrm{H} 1.69, \mathrm{C} 113.60$.

bAldrich Chemical Co., Milwaukee, Wisc., calcd. C 41.87, H 1.76, $\mathrm{N} 8.14, \mathrm{~S} / \mathrm{F}=0.84$; found $\mathrm{C} 41.81, \mathrm{H} 1.56, \mathrm{~N} 8.13$.

CAldrich Chemical Co., Milwaukee, Wisc., calcd. C 41.14, H 3.45, $\mathrm{N} 8.00, \mathrm{~S} / \mathrm{F}=1.69$; found $\mathrm{C} 40.87, \mathrm{H} 3.41, \mathrm{~N} 8.06$.

stoichiometric, as shown in Table 4. However, if the titrant is standardized against $3 \mathrm{mg}$ fluoride, then good recoveries are obtained over the 2- to 4-mg range.

Selig $^{18}$ has also applied his method to the analysis of small amounts of a fluorine-containing plasticizer, bis (2,2-dinitro-2-fluoroethy1) forma-, In high explosives. Approximately $0.2 \%$ of fluorine was determined in
Table 4. Recovery of fluoride.

\begin{tabular}{lcc}
\hline $\begin{array}{c}\text { Taken, } \\
\text { mg F }\end{array}$ & $\begin{array}{c}\text { Recovered, } \\
\text { mg }\end{array}$ & $\begin{array}{c}\text { Recovery, } \\
\%\end{array}$ \\
\hline 0.457 & 0.441 & 96.50 \\
0.685 & 0.657 & 95.91 \\
0.914 & 0.885 & 96.83 \\
1.142 & 1.125 & 98.51 \\
2.284 & 2.281 & 99.87 \\
3.427 & 3.429 & 100.06 \\
4.569 & 5.495 & 100.55 \\
5.711 & 5.782 & 101.24 \\
\hline
\end{tabular}

${ }^{\mathrm{a}}$ Standardized against $2.284 \mathrm{mg}$ fluoride. 
1-g samples of the explosive after combustion in a platinum-11ned oxys̆en bomb.

Francis et al. ${ }^{19}$ decomposed organic samples by burning them in a hot-flask combustion apparatus whose design was based on the work of Kirsten ${ }^{20}$ (Arthur H. Thomas Go., Philadelphia, Pa., catalog no. 4857-Q10). The absorbing solution consisted of $5 \mathrm{ml}$ of water containing $2.5 \mathrm{~m} M$ of sodium hydroxide; $n$-dodecanol was used as combustion accelerator. The titrant was 1anthanum nitrate, although the authors feel that thorium nitrate would serve equally well. Titrations were carried out at $\mathrm{pH} 4.0$ in order to eliminate the interference of carbon dioxide. Although titrations were feasible in a wholly aqueous medium, 60\% 2-propanol is recommended in order to increase the endpoint breaks. Unlike titrations performed in water, however, titrations in a partially nonaqueous medium were rate-dependent. Therefore, a slow and constant titration rate is recommended; this can readily be achieved by means of an automatic titrator.

According to Francts et al., ${ }^{19}$ sulfate in equimolar amounts did not affect the results, while phosphate appeared to interfere significantly. However, no data on interferences and no results of fluorine analysis were presented.
Pavel et al. ${ }^{21}$ determined fluorine in organic compounds by the direct measureisent of the fluoride concentration following combustion. Materials were decomposed by hot-f.1ask combustion. The sample size was from 1.5 to $4 \mathrm{mg}$; the fluorine content of the samples ranged from 0.5 to $2 \mathrm{mg}$. Combustion products were absorbed in water. After absorption and cooling, $4 \mathrm{ml}$ of $0.05 \mathrm{M}$ potassium hydrc xide was added and the solution diluted to $50 \mathrm{~m} 1$ with TISAB ${ }^{22}$. Standards were prepared by weighing 1 to $4 \mathrm{mg}$ of sodium fluoride and diluting to $50 \mathrm{ml}$ with $6 \mathrm{ml}$ of water and TISAB. Routinely, all solutions were assayed the same day, together with several standard solutions. Emf's were read after stirring for $3 \mathrm{~min}$. Prior to the determinations, the fluoride ISE was conditioned in TISAB containing approximate1y $5 \times 10^{-6} M$ fluoride. A calibration curve covering the range of $10^{-2}$ to $10^{-6} \mathrm{M}$ fluoride is shown in Fig. 5. Although the slope of the 11near part of the curve proved to be constant as well as close to the theoretica1 Nernstian response, the intercepts of the curve varied slightly from day to day. Thus the standards should be run every day.

The average error for 25 determinations of each of three standard compounds was less than $0.2 \%$. A slight negative bias was evident in the results, which are shown in 


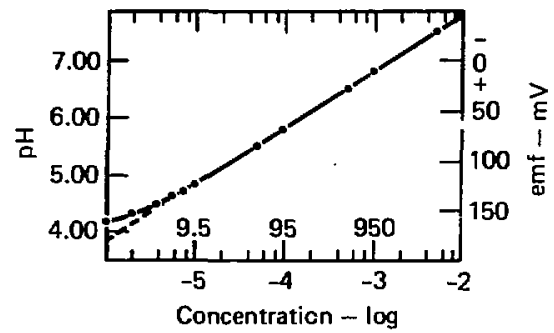

Fig. 5. Calibration curve for the electrode response in $\mathrm{pH}$ or $\mathrm{mV}$ node of the instrument vs fluoride ion concentration moles/liter or $\mu \mathrm{g} F$ in $50 \mathrm{ml}$. Measurements were made in a TISAB background at $24^{\circ} \mathrm{C}$, sample volume: $50 \mathrm{ml}$. Source: Ref. 21 , used with permission.

Table 5. For samples containing less than $0.1 \mathrm{mg}$ of fluorine, the known addition method is recommended to ensure that measurement is made in the linear portion of the curve. Pavel et al. ${ }^{21}$ claimed no interference from sulfur and phosphorus; however, no lesults are shown for sulfur and phosphorus-containing organofluoro compounds.

Shearer and Morris ${ }^{23}$ recommended decomposition of samples in oxygenflasks made of polyethylene, polypropylene, or quartz. Sample sizes ranged from 3 to $4 \mathrm{mg}$; benzoic acid (10 to $15 \mathrm{mg}$ ) was used as a combustion ald only for highly fluorinated compounds such as Teflon. The combustion products were absorbed in $10 \mathrm{~m} 1$ of $0.1 M$ sodfum hydroxide. The solution was then diluted to $100 \mathrm{ml}$. An aliquot containing 40 to $50 \mu \mathrm{g}$ of fluoride was neutr- ${ }^{-}$ized with $0.1 \mathrm{M}$ hydrochloric acid, $10 \mathrm{ml}$ of buffer solution (McIlvaine's standard buffer), ${ }^{*}$ pH 7.0, was added and the solution diluted with water to $50 \mathrm{mi}$.

*This solution contains $35.3 \mathrm{ml}$ of $0.1 N$ citric acid solution and $164.7 \mathrm{ml}$ of $0.2 \mathrm{M}$ disodium phosphate.

Table 5. Determination of fluoride in organic compounds.

\begin{tabular}{lcccc}
\hline & $\begin{array}{c}\text { No. of } \\
\text { determi- } \\
\text { nations }\end{array}$ & $\begin{array}{c}\text { Weight, } \\
\mathrm{mg}\end{array}$ & $\begin{array}{c}\text { Mean fluorine } \\
\text { found, } \\
\%\end{array}$ & $\begin{array}{c}\text { Std dev, } \\
\text { Sample }\end{array}$ \\
\hline $\begin{array}{l}\text { p-Fluorobenzoic acid } \\
\text { (theor., 13.56\% F) }\end{array}$ & 25 & $2.5-3.5$ & 13.35 & \pm 0.15 \\
$\begin{array}{l}\text { Trifluoroacetanilide } \\
\text { (theor., 30.14\% F) }\end{array}$ & 25 & $2.0-3.0$ & 27.15 & \pm 0.19 \\
$\begin{array}{l}\text { N,N-Bis-4-chloro-3- } \\
\text { trifluoromethyl- } \\
\text { diphenylurea } \\
\text { (theor., 27.33\%-F) }\end{array}$ & 25 & $2.0-3.0$ & 27.15 & \pm 0.19 \\
\hline
\end{tabular}

$a_{\text {BDH microchemical standard. }}$ 
Fluoride was then determiner by direct emf measurement, after stirring for $5 \mathrm{~min}$. The working standards were chosen so as to bracket the value found in the sample. As also reported by Pave1 et al. ${ }^{21}$ calibration curves had to be prepared dally. The fluoride ISE was conditioned by storage in a solution containing 40 to $50 \mu \mathrm{g}$ fluoride. Some results are shown in Table 6. No data are given for compounds containing sulfur and phosphorus.

Terry and Kasler ${ }^{24}$ decomposed organic samples in a polypropylene oxygen-flask. The sample size ranged from 1 to $10 \mathrm{mg}$; the absorbing solution consisted of exactly $50 \mathrm{ml}$ of
CDTA-TISAB, * wh1ch simplified the determination. After absorption of the combustion products, the emf was determined directly in this solution, with a recorder used to obtain the steady-state voltage. Calculations were made directly from a calibration curve. The callbrating standards in CDTA-TISAB may be stored in glass. Results for a variety of organometallic compounds contalning (in addition to fluorine) mercury, tin, thallium, bromine, sulfur, phosphorus, and boron are shown in Table 7. The

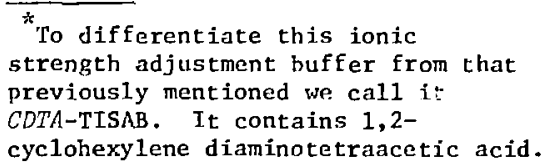
strength adjustment buffer from that previously mentioned we call it: CDTA-TIS $A B$. It contains $1,2-$ cyclohexylene diaminotetraacetic acid.

Table 6. Microdatermination of fluorine by specific ion electrode analysis following oxygen flask combustion using a polypropylene Elisk.

\begin{tabular}{|c|c|c|c|c|c|}
\hline Compound & $\begin{array}{l}\text { No. of } \\
\text { determi- } \\
\text { nations }\end{array}$ & $\begin{array}{c}\text { Fluori } \\
\text { Theory, } \\
\%\end{array}$ & $\frac{\text { ntent }}{\text { Mean, }}$ & $\begin{array}{l}\text { Std } \\
\text { dev }\end{array}$ & $\begin{array}{c}\text { Av abs } \\
d \leq v\end{array}$ \\
\hline p-F1uorobenzoic acid ${ }^{a}$ & 6 & 13.56 & 13.29 & 0.30 & 0.35 \\
\hline $\begin{array}{l}\text { Trifluoroacetanilide } \\
\text { (TFA) }^{a}\end{array}$ & 6 & 30.14 & 30.48 & 0.38 & 0.42 \\
\hline TFA + benzoic acid & 4 & & 29.91 & 0.27 & 0.28 \\
\hline $\begin{array}{l}\text { m-Trlfluoromethylbenzo } \\
\text { acid (TFMB) }\end{array}$ & 6 & 29.98 & 30.25 & 0.36 & 0.37 \\
\hline TFMB + benzoic actd & 3 & & 30.00 & 0.80 & 0.60 \\
\hline Teflon ${ }^{b}$ & 3 & 75.98 & 65.23 & 7.27 & 10.75 \\
\hline Teflon + benzolc acid & 7 & & 75.86 & 0.29 & 0.24 \\
\hline
\end{tabular}

arganic analytical standard, British Drug Houses.

${ }^{b}$ Sample supplied in an IUPAC collaborative study. 
Table 7. Microdetermination of fluorine.

\begin{tabular}{lccc}
\hline & Sample & Fluorine content \\
welght, \\
Compound & mgeory, & $\begin{array}{c}\text { Found, } \\
\mathbf{z}\end{array}$ \\
\hline
\end{tabular}

$1 \mathrm{~F} \longrightarrow \mathrm{OCH}_{3}^{\mathrm{C}}-\mathrm{CH}$

$\begin{array}{lll}5.175 & 10.06 & 10.43 \\ 4.340 & & 10.41\end{array}$<smiles>FC(F)(F)c1cccc(CSc2cccc(C(F)(F)F)c2)c1</smiles>

$2.678 \quad 23.27$

2

$1.694 \quad 18.46$

18.58

3<smiles>CC(C)([Sb]c1ccccc1C(F)(F)F)c1ccccc1</smiles>

$4 \int_{2}^{\mathrm{TIBr}}$

$3.521 \quad 19.88$

19.88

4.827

19.07

(N)

4. 476

9.213

4.617

2.979

21.55

22.08

21.54

21.49

22.05

$\mathrm{CH}_{3}$

$\left.6\right|_{3} ^{\mathrm{B}}$

3.150
6.005
2.610

26. 53

25.65

28. 31 


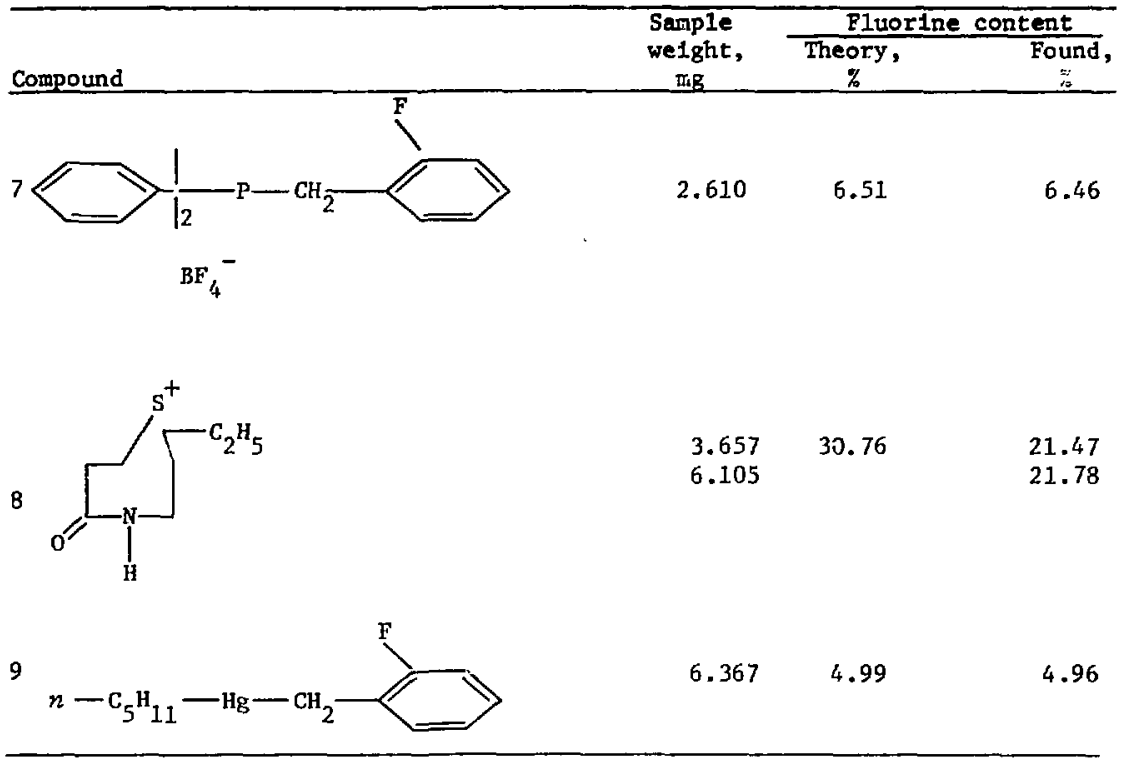

fluorine content of these compounds varied from 6 to $38 \%$. Only boron interfered, yfelding high results even when an attempt was made to complex it with mannitol.

Rittner and $\mathrm{Ma}^{25}$ have sucessfully elfminated the Interference of boron in the determination of fluorine in organic compounds. Samples were decomposed by sodium peroxide fusion In a microbomb, they contained between 0.5 and $5.0 \mathrm{mg}$ fluorine. The fusion mixture conststed of two parts of potassium nitrate and one part of sucrose. Prior to fignition, samples were conered wlth approximately $100 \mathrm{mg}$ of this mixture and $1.5 \mathrm{~g}$ sodium per- oxide. After fusion, cooling, and transfer, the solution was diluted to $250 \mathrm{ml}$ in a plastic volumetric flask. A total of $10 \mathrm{ml}$ of TISAB was added to an aliquot containing between 10 and $100 \mu \mathrm{g}$ fluoride and the solution was diluted to $100 \mathrm{ml}$. The standard solutions, containing 10 and $100 \mathrm{\mu g}$ fluoride, were treated in the same fashion. The fluoride ISE was conditioned by immersion in a solution containing 10 to $100 \mu \mathrm{g}$ fluoride and rapid stirring until a constant emf reading was obtained.

Although the fluoride concentration can be obtained from a calibration curve, it is simpler and more 
accurate to determine it mathematically, by using the following linear equation:

$\mathrm{F}^{-}$(concentration in sample)

$$
=\text { antilog }
$$

$\left[\frac{\text { emf, } 10 \mu g \text { std - emf of sample }}{\text { emf, } 10 \mu g \text { std - emf } 100 \mathrm{ug} \text { std }}\right]$

The presence of a 50-fold excess of phosphate had a negligible effect on the determination of fluoride. Resulas are shown in Table 8 .
Although the direct potentiometric measurement in the presence of a suitable TISAB is the simplest technique for determining fluoride in the presence of such interfering elements as sulfur, phosphorus, and boron, the accuracy of this technique is not as high as can be rchleved by a potentiometric titration. A method for the potentiometric titration of fluoride in organic compounds containing

Table 8. Microdetermination of fluorine by $\mathrm{Na}_{2} \mathrm{O}_{2}$ fusion and $\mathrm{mV}$ measurement in TISAB.

\begin{tabular}{|c|c|c|c|}
\hline \multirow[b]{2}{*}{ Compound } & \multirow[b]{2}{*}{$\begin{array}{l}\text { Weight, } \\
\text { mg }\end{array}$} & \multicolumn{2}{|c|}{ Fluorine content } \\
\hline & & $\begin{array}{c}\text { Theory, } \\
\%\end{array}$ & $\begin{array}{c}\text { Found, } \\
\%\end{array}$ \\
\hline p-Fluorobenzoic acid & $\begin{array}{r}15.400 \\
23.892 \\
3.070\end{array}$ & 13.56 & $\begin{array}{l}13.55 \\
13.98 \\
13.73\end{array}$ \\
\hline Pentafluorophenoxyacetic acid & $\begin{array}{l}10.521 \\
14.622\end{array}$ & 39.24 & $\begin{array}{l}39.04 \\
39.62\end{array}$ \\
\hline 4-Fluoro-3-nitrophenylsulfons & $\begin{array}{l}14.033 \\
16.519 \\
10.624\end{array}$ & 11.04 & $\begin{array}{l}10.97 \\
11.05 \\
11.00\end{array}$ \\
\hline p-Carboxybenzotrifluoride & $\begin{array}{l}7.916 \\
9.835 \\
6.855\end{array}$ & 29.98 & $\begin{array}{l}29.67 \\
30.19 \\
30.11\end{array}$ \\
\hline 3,5-D1(trifluoromethyl)benzolc acid & $\begin{array}{l}9.873 \\
8.668\end{array}$ & 44.16 & $\begin{array}{l}43.72 \\
44.39\end{array}$ \\
\hline 4-Fluoroantline & 13.847 & 17.10 & 16.98 \\
\hline 2-Fluoro-1sopropylbenzene & $\begin{array}{r}10.830 \\
9.764\end{array}$ & 13.75 & $\begin{array}{l}13.64 \\
13.76\end{array}$ \\
\hline $\begin{array}{l}\text { p-FIuorobenzolc acid } \\
\quad+\text { Borfc acid }\end{array}$ & $\begin{array}{l}5.017 \\
5.385\end{array}$ & 13.56 & 13.33 \\
\hline $\begin{array}{l}\text { Pentafluorophenoxyacetic acid } \\
+ \text { Boric Acld }\end{array}$ & $\begin{array}{l}5.646 \\
6.024\end{array}$ & 39.24 & 39.13 \\
\hline
\end{tabular}


phosphorus has been described by Sel1g. ${ }^{26}$ After combustion of the sample in a vycor oxygen-flask, the phosphorus was oxidized to orthophosphate by alkaline hypobromfte. The solution was then actdifled to $\mathrm{pH} 4.5$ and the excess bromine and carbon diaxide were expelled by bolling. Phosphate was then adsorbed on zinc oxide, ${ }^{27}$ which need not be removed prior to titration of the fluoride. The titrant was $0.02 M$ lanthanum nitrate; the titration medium was $50 \%$ ethanol at $\mathrm{pH} 5$ to 7 . Results are shown in Table 9. This method was also used for the assay of fluorine in inorganic hexafluorophosphates.
A1 though ammonlum hexafluorophosphate ylelded clean combustions, the potasslum analog ylelded only 80 to $90 \%$ recoveries. Addition of 5 to $10 \mathrm{mg}$ of paraffin as a combustion afd, however, usually ensured clean combustions. The results are shown in Tab1e 10.

Sel $1 \mathrm{~g}^{26}$ recommended the use of an automatic titrator, since equilibrium potentials were established rather slowly in the partially nonaqueous medium. Also, after reaching a maximum after addition of each increment of titrant, potentials drifted slowly toward more negative values. For manual titrations, Selig used the

Table 9. Determination of fluorine in the presence of phosphorus.

\begin{tabular}{|c|c|c|c|c|c|}
\hline \multirow[b]{2}{*}{ Compound } & \multirow[b]{2}{*}{$\begin{array}{c}\text { Weight, } \\
\text { mg }\end{array}$} & \multicolumn{3}{|c|}{ Fluor tise content } & \multirow[b]{2}{*}{$\begin{array}{l}P / F \\
\text { ratio }\end{array}$} \\
\hline & & $\begin{array}{c}\text { Theory, } \\
\%\end{array}$ & $\begin{array}{c}\text { Found, } \\
\%\end{array}$ & $\begin{array}{c}\text { Error, } \\
\%\end{array}$ & \\
\hline $\begin{array}{l}\text { Tetramethylammonium } \\
\text { hexafluorophosphate }^{a}\end{array}$ & $\begin{array}{l}4.591 \\
4.668 \\
5.790 \\
4.456 \\
4.895\end{array}$ & 52.02 & $\begin{array}{l}52.03 \\
52.02 \\
51.97 \\
52.14 \\
52.07\end{array}$ & $\begin{array}{r}-0.01 \\
0.00 \\
-0.05 \\
+0.12 \\
+0.05\end{array}$ & 0.27 \\
\hline $\begin{array}{l}\text { Triphenylmethyl hexa- } \\
\text { fluorophosphate }{ }^{b}\end{array}$ & $\begin{array}{r}9.65 \\
10.85\end{array}$ & 29.36 & $\begin{array}{l}29.25 \\
29.27\end{array}$ & $\begin{array}{l}-0.11 \\
-0.09\end{array}$ & 0.27 \\
\hline $\begin{array}{l}\text { Tris(1H, IH-heptaf1uoro- } \\
\text { buty1)phosphatec }\end{array}$ & $\begin{array}{l}3.517 \\
4.132 \\
3.477 \\
5.060 \\
4.280\end{array}$ & & $\begin{array}{l}60.89 \\
60.98 \\
60.90 \\
60.76 \\
60.51\end{array}$ & $\begin{array}{l}+0.19 \\
+0.17 \\
+0.20 \\
+0.06 \\
-0.19\end{array}$ & 0.08 \\
\hline
\end{tabular}

\footnotetext{
${ }^{a}$ Aldrich Chemical Co., calcd. C 21.93, N 6.39; found C 22.04, N 6.40.

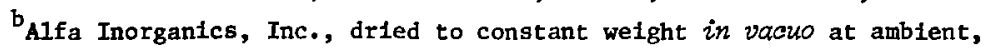
$10 \mu$.

${ }^{C}$ Peningular Chemresearch, $\left(\mathrm{CF}_{3} \mathrm{CF}_{2} \mathrm{CH}_{2} \mathrm{O}\right){ }_{3}^{\mathrm{PO}}$, purity $98 \%$ by gas chromatography. Calcd. \% $F$ on the assumption that the 1mpurity does not contaln $F$ is $60.70 \%$.
} 
Table 10. Determination of fluorine in Inorganic hexafluorophosphates.

\begin{tabular}{|c|c|c|c|c|}
\hline \multirow[b]{2}{*}{ Compound } & \multirow[b]{2}{*}{$\begin{array}{c}\text { Weight, } \\
\mathrm{mg}\end{array}$} & \multicolumn{3}{|c|}{ Fluorine content } \\
\hline & & $\begin{array}{c}\text { Theory, } \\
\%\end{array}$ & $\begin{array}{c}\text { Found, } \\
\%\end{array}$ & $\begin{array}{c}\text { Error, } \\
\%\end{array}$ \\
\hline Ammonium hexafluorophosphate ${ }^{a}$ & $\begin{array}{l}3.988 \\
4.638 \\
3.763\end{array}$ & 69.93 & $\begin{array}{l}69.76 \\
69.83 \\
70.16\end{array}$ & $\begin{array}{l}-0.17 \\
-0.10 \\
+0.23\end{array}$ \\
\hline Potassium hexafluorophosphate $e^{b}$ & $\begin{array}{l}3.621 \\
3.124 \\
3.793 \\
3.137 \\
3.503\end{array}$ & 61.93 & $\begin{array}{l}61.43 \\
61.61 \\
61.81 \\
61.37 \\
61.82\end{array}$ & $\begin{array}{l}-0.50 \\
-0.32 \\
-0.12 \\
-0.56 \\
-0.11\end{array}$ \\
\hline
\end{tabular}

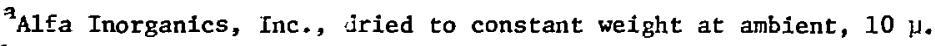

${ }^{\mathrm{A}}$ Alfa Inorganics, Inc., dried to constant weight at ambient, $10 \mu$; burned in the presence of approx 5 to $10 \pi /$; of paraffin.
}

maximum emf attained before adding another increment of titrant. The phosphorous-to-fluorine ratios in the compounds analyzed varied from 0.45 to 2.28; the absolute error in fluorine content was less than $0.2 \%$, and the standard deviation of the absolute error was $0.6 \%$. Omission of the oxidation step for phosphorus ylelded high results for fluorine, probably due to the presence of hypophosphite, which was found to interfere.

Hozumi and Akinroto ${ }^{28}$ burned samples in a quartz oxygen-flask, absorbing the gaseous products in water. Sample sizes varied from 2 to $4 \mathrm{mg}$, their fluoride content varied from 100 to $1000 \mu \mathrm{g}$. The solutions were transferred to $100-\mathrm{ml}$ volumetric flasks with $50 \mathrm{ml}$ water and diluted to volume with TISAB solution. The emf's were measured directly after 5 min. Standards were prepared in TISAB solution. The results for some organic compounds are shown in Table 11. The fluorine content varled from 10 to $40 \%$; the standard deviation was $0.13 \%$. The low results obtained on combustion of fluorinecontaining compounds in borosilicate glass were attributed to boron by experiment.

Kakabadse et ar. ${ }^{29}$ recommended a pyrohydrolytic technique 30 for the decomposition of both inorganic and organic samples. They applied this technique to the determination of fluorlne in Teflon, cocoa, tea, tobacco, and bacterla. Fluoride concentrations were determined by direct measurement vs known standards. 
Table 11. Mlcrodetermination of organtc fluorine.

\begin{tabular}{|c|c|c|c|c|}
\hline \multirow[b]{2}{*}{ Compound } & \multirow[b]{2}{*}{$\begin{array}{c}\text { WeIght, } \\
\mathrm{mg}\end{array}$} & \multicolumn{3}{|c|}{ Fluorine content } \\
\hline & & $\begin{array}{c}\text { Theory, } \\
\%\end{array}$ & $\begin{array}{c}\text { Found, } \\
\% \\
\end{array}$ & $\begin{array}{c}\text { Errox, } \\
\%\end{array}$ \\
\hline Fluoroacetamide & $\begin{array}{l}4.193 \\
3.599 \\
3.387\end{array}$ & 24.66 & $\begin{array}{l}24.56 \\
24.87 \\
24.65\end{array}$ & $\begin{array}{l}-0.10 \\
+0.22\end{array}$ \\
\hline 2,4-Dinitrofluorobeilzene & $\begin{array}{l}3.653 \\
3.390 \\
3.906\end{array}$ & 10.21 & $\begin{array}{l}10.22 \\
10.23 \\
10.28\end{array}$ & $\begin{array}{l}+0.01 \\
+0.02 \\
+0.07\end{array}$ \\
\hline Fluorobenzene & $\begin{array}{l}4.402 \\
3.286 \\
4.078\end{array}$ & 19.77 & $\begin{array}{l}19.60 \\
19.66 \\
19.86\end{array}$ & $\begin{array}{l}-0.17 \\
-0.11 \\
+0.09\end{array}$ \\
\hline Trifluoroacetylacetone & $\begin{array}{l}3.473 \\
3.379 \\
2.826\end{array}$ & 36.99 & $\begin{array}{l}36.82 \\
37.07 \\
36.84\end{array}$ & $\begin{array}{l}-0.17 \\
+0.08 \\
-0.15\end{array}$ \\
\hline 3,5-Bis (trif1uoro-methy1) & 3.285 & 42.04 & 42.31 & +0.27 \\
\hline acetantlide & $\begin{array}{l}3.663 \\
3.193\end{array}$ & & $\begin{array}{l}42.19 \\
41.98\end{array}$ & $\begin{array}{l}+0.15 \\
-0.06\end{array}$ \\
\hline $\begin{array}{l}\text { 3-Trifluoromethyl } \\
\text { acetanilide }\end{array}$ & $\begin{array}{l}4.053 \\
3.660 \\
3.511\end{array}$ & 28.06 & $\begin{array}{l}28.04 \\
28.16 \\
28.03\end{array}$ & $\begin{array}{l}-0.02 \\
+0.10 \\
-0.03 \\
\sigma=0.13(\%)\end{array}$ \\
\hline
\end{tabular}

Jones et $a l^{31}$ used reductive cleavage with sodium biphenyl reagent (diphenyl sodium - dimethoxyethane comp?ex) for the decomposition of some fluorine-containing aromatic pharmaceuticals, such as 5-fluorouracil, 5-fluorouridine and derivattves, and chlorofluoroazepam and derivatives. The resulting fluoride was determined by direct emf neasurewent vs known standards, Measurewents were made in an alcohollc acetate buffer of $\mathrm{pH} 5.5$ and lonic strength 5M. For 12 compounds con- talning from 4 to $21 \%$ of fluorine, the average disolute error was less than $0.17 \%$. This method seems of rather Ilmited use, since the compounds must be at least slightly soluble $(0.1-0.2 \%, w / v)$ in tetrahydrofuran or ethylene glycol dimethyl ether. Compounds that are not soluble in these solvents to the same extent without application of heat are dissolved in a small amount of dimethyl sulfoxide before addition of the other solvent. However, dimethyl sulfoxide slowly decomposes the sodium biphenyl 
reagent. Also, these latter compounds require, after destruction of the excess biphenyl reagent, oxfdation with hydrogen peroxide under reflux for one hour. Th1s method has been applied only to a limited number of compounds; no materials containing more than $21 \%$ of fluorine were determined.

Helesic ${ }^{32}$ decomposed samples in an oxygen-flask, not stating however, the materlal of the flask. Liquid samples were sealed in polyethylene capillaries; solid samples were welghed into small polyethylene bags prior to wrapping in the sample carrier. Samples contained 1 to $2 \mathrm{mg}$ of fluorine; the absorbing medium was water. Solutions were neutralized with $0.05 \mathrm{M}$ sodium hydroxide to the bromcresol purple endpoint ( $\mathrm{pH}$ 6.8) and carbon dioxide was removed by flushing with nitrogen. Fluoride was titrated potentiometrically with $0.01 \mathrm{M}$ lanthanum nitrate in a medium contalning $80 \%$ ethanol. Similar titration curves were obtained with praseodymium-, gadolinium-, and ytterbium nitrates. For highly fluorinated compounds, the carrier paper was impregnated with potassium nitrate as a combustion aid. Results for eight compounds (shown in Table 12) were within $\pm 0.3 \%$ absolute. None of the compounds contained sulfur or phosphorus. Helestc agrees with $\operatorname{Sellg}^{17}$ that increasing acidity (nitric acid) decreases the sensitivity of the titration but recommends closer $\mathrm{pH}$ control (pH 6.8) than that recommended by Selig (pH 5 to 7).

Hassan ${ }^{33}$ examined the response of an Orion fluoride ISE in various partially nonaqueous media. He found a 50:50 (v/v) mixture of dioxane and water the best medium for both the direct and potentiometric procedures. Organic compounds were combusted in a polyethlene oxygen-flusk and the gaseous products absorbed in distilled water. The optimum $\mathrm{pH}$ was betwean 3 and 6 . The titrant was $0,005 \mathrm{M}$ thorium nitrate. The results obtained for five organic compounds are shown in Table 13. The average recovery was $99.1 \%$ and the mean absolute error was $\pm 0.3 \%$.

Schreiber and Frei ${ }^{34}$ described the microdeterminacion of fluorine in organic fluoroborates. Samples wers combusted by the Wickbold oxyhydrogen technique and absorbed in $1 M$ sodium hydroxide. The solution was then evaporated to dryness; $20 \mathrm{mI}$ TISAB was added and the $\mathrm{pH}$ adjusted to 5.5 with hydrochloric acid. Fluoride was determined by direct emf measurement after preparation of a calibration curve with standa: ds. Some results are show in Table 14, from which it can be seen that the oxygen-flask combustion yielded low results. From 0.1 to $5 \mathrm{mg}$ fluoride were determined with a coefficlent of variation of $1 \%$. 
Table 12. Results of fluoride analysis in organic compounds.

\begin{tabular}{|c|c|c|c|c|}
\hline \multirow[b]{2}{*}{ Compound } & \multirow[b]{2}{*}{$\begin{array}{c}\text { Weight, } \\
\text { mg }\end{array}$} & \multicolumn{3}{|c|}{ Filuorine content } \\
\hline & & $\begin{array}{c}\text { Theory, } \\
\%\end{array}$ & $\begin{array}{c}\text { Found, } \\
\%\end{array}$ & $\begin{array}{c}\text { Error, } \\
\% \\
\end{array}$ \\
\hline $\begin{array}{l}\text { 4-Hydroxy -5-f1uoro- } \\
\text { pyrimidine }\end{array}$ & $5.157-16.526$ & 16.65 & $16.66^{\mathrm{a}}$ & -0.32 to +0.45 \\
\hline $\begin{array}{l}\text { Tetrafluorotetra- } \\
\text { chloropropane }\end{array}$ & $4.142-10 \cdot 370$ & 29.94 & $29.92^{\mathrm{b}}$ & -0.35 to +0.20 \\
\hline $\begin{array}{l}\text { 1-Methy1-2- }(1,2,2- \\
\text { trifluoro-1-chloro })- \\
\text { pyrrolidine }\end{array}$ & $\begin{array}{l}5.626 \\
5.510\end{array}$ & 28.27 & $\begin{array}{l}28.26 \\
28.48\end{array}$ & $\begin{array}{l}-0.01 \\
+0.21\end{array}$ \\
\hline $\begin{array}{l}\text { 3-(2-tetrahydrofurfury1)- } \\
2,3,3 \text {-trifluoropropionic } \\
\text { acid methyl ester }\end{array}$ & $\begin{array}{l}5.024 \\
4.627\end{array}$ & $\begin{array}{l}26.84 \\
26.77\end{array}$ & 26.58 & $\begin{array}{l}-0.26 \\
-0.07\end{array}$ \\
\hline $\begin{array}{l}\text { 3, 3-Bis (diethylamino)-2-- } \\
\text { fluoroacrylic acid } \\
\text { methyl ester }\end{array}$ & 4.933 & 8.17 & 8.06 & -0.11 \\
\hline $\begin{array}{l}\text { 2-Methy1-3,3,4-trifluoro- } \\
\text { 4-chlorobutanoic acid }\end{array}$ & 5.501 & 29.91 & 30.21 & +0.30 \\
\hline $\begin{array}{l}\text { 2-Methy1-3,3,4-tri- } \\
\text { fluoroxyethane }\end{array}$ & $\begin{array}{l}5.757 \\
5.820\end{array}$ & 45.21 & $\begin{array}{l}45.37 \\
45.41\end{array}$ & $\begin{array}{l}+0.16 \\
+0.20\end{array}$ \\
\hline Polytetra:luoroethylene & $3.150-3.333$ & 75.98 & $75.90^{c}$ & -0.18 to +0.11 \\
\hline
\end{tabular}

$a_{\text {Average of }} 18$ determinaticns, standard deviation for single value $0.21 \%$, mean standard deviation $0.05 \%$;

$b_{\text {Average of }} 6$ determinations, standard deviation of single value $0.23 \%$, mean standard deviation $0.09 \%$;

Average of 4 determinations; a mixture of isomers.

With the recent introduction of special graph paper by Orion Research Inc., Gran's plot titrations ${ }^{35-37}$ have recefved a new impetus. This paper has an antilog axis which directly converts the observed emf's to concentrations and automatically corrects for changes in sample volume caused by the addition of increments of titrant. This technique permits measurements to be made with greater precision than can be obtained by the known addition technique. Selig 38 used this technique for the titration of 1 to $4 \mathrm{mg}$ fluoride with $0.02 \mathrm{M}$ lanthanum nitrate in an aqueous medium. Combustion was performed In a Vycs:: oxygen-flask or a platinum-lined oxygen-bomb, as described above. ${ }^{17,18}$ The absolute error was $\pm 1 \%$, and the 
lower practical 1imit of the method was near $0.6 \mathrm{mg}$ of fluoride (due to the slow establishment of equilibrium at this low fluoride level). The titer of the lanthanum solution was established by using an aliquot of a fluoride solution containing approximately $1.5 \mathrm{mg}$ of fluorfde. In this determination, sulfate and phosphate

Table 13. Determination of some organically bound fluorine compounds by potentiometric titration in $50 \%$ aqueous Dioxan using the fluoride electrode after closed flask.

\begin{tabular}{|c|c|c|c|}
\hline Conpound & $\begin{array}{c}\text { Fluorine } \\
\text { Theory, } \\
\%\end{array}$ & $\begin{array}{c}\text { content } \\
\text { Found, } \\
\%\end{array}$ & $\begin{array}{c}\text { Recovery, } \\
z\end{array}$ \\
\hline 1-F1uoroanthraquinone & 8.47 & $\begin{array}{l}8.3 \\
8.2 \\
8.2\end{array}$ & $\begin{array}{l}98.0 \\
96.8 \\
96.8\end{array}$ \\
\hline p-Fluorobenzolc acld & 13.57 & $\begin{array}{l}13.3 \\
13.4 \\
13.3\end{array}$ & $\begin{array}{l}98.0 \\
98.8 \\
98.0\end{array}$ \\
\hline p-Fluoroantsole & I5.08 & $\begin{array}{l}15.0 \\
14.8 \\
14.8\end{array}$ & $\begin{array}{l}99.5 \\
98.1 \\
98.1\end{array}$ \\
\hline p-F1uorophenol & 16.96 & $\begin{array}{l}16.8 \\
16.8 \\
16.7\end{array}$ & $\begin{array}{l}99.1 \\
99.1 \\
98.5\end{array}$ \\
\hline Perfluoroheptane & 78.35 & $\begin{array}{l}78.0 \\
78.0 \\
77.9\end{array}$ & $\begin{array}{l}99.6 \\
99.6 \\
99.4\end{array}$ \\
\hline
\end{tabular}

probably interfere. However, the known addition technique may be used in combination with Gran's plots in a TISAB medium, even in the presence of various commonly interfering cations and anions. 39 The accuracy of this method is within $\pm 5 \%$, 1imited by the accuracy of emf readings and plot extrapolations. At the fluoride level of $3 \mathrm{ppm}$, sulfa:e : l. phosphate at more than 3000 times the fluoride concontration did not interfere.

Using this method with an interactive computer technique has achieved an accuracy of $\pm 2 \%{ }^{40}$ Although this tecianique was applied only to inorganic fluoride samples, it no doubt is also applicable to organic samples after combustion. 41

\section{Conclusion}

Since 1969 a number of workers have used the fluoride ISE for the determination of fluorine in organic compounds. A summary of the more important methods is given in Table 15. The methods of decomposition were

Table 14. Determination of fluoride in boron-containing organic matrices.

\begin{tabular}{|c|c|c|c|}
\hline \multirow[b]{3}{*}{ Compoundi } & \multicolumn{3}{|c|}{ Fluorine content } \\
\hline & \multirow[b]{2}{*}{$\begin{array}{c}\text { Theory, } \\
\% \\
\end{array}$} & \multicolumn{2}{|c|}{ Found ${ }^{\mathrm{a}}$} \\
\hline & & $\begin{array}{c}\text { Closed flask } \\
\text { combustion, } \\
\%\end{array}$ & $\begin{array}{c}\text { Wickbold } \\
\text { combustion, } \\
\%\end{array}$ \\
\hline $\left.\begin{array}{l}1 \\
2 \\
3 \\
4\end{array}\right\} \begin{array}{l}\text { Fluoroborates of organic } \\
\text { cations }\end{array}$ & $\begin{array}{l}19.2 \\
43.7 \\
39.0 \\
30.4\end{array}$ & $\begin{array}{l}17.2 \\
41.7 \\
26.5 \\
21.3\end{array}$ & $\begin{array}{l}18.9 \\
43.5 \\
39.2 \\
30.1\end{array}$ \\
\hline
\end{tabular}

Mean values of 8 determinations are given. 
Table 15. Determination of fluorine in organic compounds: summary of methods.

\begin{tabular}{|c|c|c|c|c|c|c|c|}
\hline $\begin{array}{l}\text { Ref- } \\
\text { erence }\end{array}$ & $\begin{array}{l}\text { Method } \\
\text { of } \\
\text { combustion }\end{array}$ & $\begin{array}{c}\text { Combustion } \\
\text { afd }\end{array}$ & $\begin{array}{l}\text { Medium } \\
\text { pH }\end{array}$ & $\begin{array}{l}\text { Method } \\
\text { of } \\
\text { titration }\end{array}$ & Titrant & $\begin{array}{l}\text { Amount of } \\
\text { fluoride } \\
\text { determined }\end{array}$ & $\begin{array}{l}\text { Inter- } \\
\text { ferences }\end{array}$ \\
\hline 19 & Hot flask & $\begin{array}{l}\text { Water }+ \\
\text { docecano1 }\end{array}$ & $\begin{array}{l}\text { Aqueous } \\
\text { or } 60 \% \\
\text { organic, } \\
4.0\end{array}$ & $\begin{array}{l}\text { Potentio- } \\
\text { metric }\end{array}$ & $\begin{array}{l}\text { La (III) } \\
\text { or } \\
\text { Th (IV) }\end{array}$ & Not given ${ }^{a}$ & $\mathbf{P}^{\mathbf{a}}$ \\
\hline 21 & Hot flask & Water & $\begin{array}{l}\text { Aqueous, } \\
\text { TISAB }\end{array}$ & $\begin{array}{l}\text { Known } \\
\text { addition }\end{array}$ & $\mathrm{NaF}$ & $0.5-2 \mathrm{mg}$ & $\begin{array}{l}\text { None } \\
\text { (incl. } \\
\text { P,S) }\end{array}$ \\
\hline 17 & $\begin{array}{l}\text { Oxygen- } \\
\text { flask, } \\
\text { Vycor }\end{array}$ & None & $\begin{array}{l}\text { Aqueous, } \\
5-7\end{array}$ & $\begin{array}{l}\text { Potentio- } \\
\text { metric }\end{array}$ & $\mathrm{La}$ (III) & $2-4 \mathrm{mg}$ & $\mathbf{P}$ \\
\hline 14 & $\begin{array}{l}\text { Oxygen- } \\
\text { flask } \\
\text { poly- } \\
\text { carbonate }\end{array}$ & Docecanol & $\begin{array}{l}80 \% \\
\text { ethanol } \\
0.01 \mathrm{M} \\
\mathrm{HNO}_{3}\end{array}$ & $\begin{array}{l}\text { Potentio- } \\
\text { metric }\end{array}$ & $T h$ (IV) & $1-3 \mathrm{mg}$ & $\mathrm{S}, \mathrm{P}$ \\
\hline 23 & $\begin{array}{l}\text { Oxygen- } \\
\text { flask } \\
\text { poly- } \\
\text { propylene }\end{array}$ & $\begin{array}{l}\text { Benzoic } \\
\text { ac1d } \\
\text { for } F \text { on } 1 y\end{array}$ & $\begin{array}{l}\text { TISAB, } \\
7.0\end{array}$ & $\begin{array}{l}\text { Known } \\
\text { addition }\end{array}$ & $\mathrm{NaF}$ & $40-50 \mu \mathrm{g}$ & $\begin{array}{l}\text { Not } \\
\text { given }\end{array}$ \\
\hline 24 & $\begin{array}{l}\text { Oxygen- } \\
\text { flask, } \\
\text { poly- } \\
\text { propylene }\end{array}$ & None & $\begin{array}{l}\text { TISAB, } \\
5-5.5\end{array}$ & Direct & none & $1-10 \mathrm{mg}$ & Only B \\
\hline 25 & $\begin{array}{l}\text { Part } \\
\text { mictobomb }\end{array}$ & Peroxide & $\begin{array}{l}\text { TISAB, } \\
5-5.5\end{array}$ & Direct & none & $10-100 \mu \mathrm{g}$ & $\begin{array}{l}\text { None } \\
\text { (incl. } \\
\mathrm{P}, \mathrm{S}, \mathrm{B} \text { ) }\end{array}$ \\
\hline 38 & $\begin{array}{l}\text { Oxygen- } \\
\text { flask or } \\
\text { bomb }\end{array}$ & None & $\begin{array}{l}\text { Aqueous, } \\
5-7\end{array}$ & $\begin{array}{l}\text { Known } \\
\text { addit1on- } \\
\text { Gran's } \\
\text { plots }\end{array}$ & La (III) & $1-4 \mathrm{mg}$ & $\mathrm{S}, \mathrm{P}$ \\
\hline 39 & $\begin{array}{l}\text { Oxygen- } \\
\text { flask or } \\
\text { bomb }\end{array}$ & None & $\begin{array}{l}\text { TISAB, } \\
5-5.5\end{array}$ & $\begin{array}{l}\text { Known } \\
\text { addition- } \\
\text { Gran's } \\
\text { plots }\end{array}$ & $\mathrm{NaF}$ & $8-600 \mu g$ & None \\
\hline
\end{tabular}

To data given for results of interferences.

pyrohydrolysis, reduction with sodium blpheny1, peroxide fusion, and oxygenflask combustion (which is preferred by nost workers). The methods of determination were potentiometric titration with rare earth titrants (1anthanum and thorlum nitrate are preferred), direct measurement of the fluoride concentration, and the known addition method in combination with Gran's plots. Although none of the techniques is yet universally accepted, the variety available should be useful for most analytical problens. 


\section{References}

1. T. S. Ma, "Organic Analysis: Fluorine," In Treatise or Analytical Chemistry, Part II, Vol. 12, I. M, Kolthoff and P. J. Elving, Eds. (Intersclence, New York, 1965), P. 117.

2. A. M. G. MacDonald, "The Oxygen-Flask Method," In Advances in Analytical Chemistry and Instmonentation, Vol. 4, C. N. Rel11y, Ed. (Interscience, New York, 1965), p. 103.

3. Analytical Methods Committee Report, Analyst, 97, 734 (1972).

4. H. H. Willard and O. B. Winter, Ind. Eng. Chem., Anal. Ed., 5, 7 (1933).

5. C. A. Horton, "Trends in the Determination of Fluorine," In Advances in Analytical Chemistry and Instmonentation, Vol. 1, C. N. Reilly, Ed. (interscience, New York, 1960), p. 164.

6. C. A. Horton, "Fluorine," in Treatise on Analytical Chemistry, Part II, Vol. 7, I. M. Kolthoff and P. J. Elving, Eds. (Interscience, New York, 1961), p. 246.

7. F. H. Oliver, Analyst, 91, 771 (1966).

8. H. S. Clark and 0. W. Rees, IZlinois State Geol. Sumvey Rept. Invest., No. 169 (1954).

9. R. H. Shoup, Anal. Chem., 29, 1216 (1957).

10. T. R. F. W. Fenne11, Chemistry and Industry, 1955, 1404.

11. A. F. Colson, Analyst, 88, 26 (1963).

12. R. Belcher and A. M. G. MacDonald, Mikrochim. Acta, 1956, 899.

13. R. Belcher and A. M. G. MacDonald, Mikrochim. Acta, 1957, 510.

14. T. S. Light and R. F. Mannion, Anal. Chem., 41, 107 (1969).

15. J. J. Lingane, Anal. Chem., 39, 881 (1967).

16. J. J. Lingane, Anal. Chem., 40, 935 (1968).

17. W. Selig, z. onalyt. Chem. 249, 30 (1970).

18. W. Selig, Lawrence Livermore Laboratory, LIvermore, Calif,, Rept, UCID15452 (1969); cf. Chem. Abstr., 70, 116758c (1969).

19. H. J. Francis, J. H. Deomarine, and D. D. Persing, Microchem. J., 14, 580 (1969).

20. H. J. Kirsten, Microchem. J., 7, 34 (1963).

21. J. Pavel, R. Kuebler, and H. Wagner, Miarochem. J, 15, 192 (1970).

22. M. S. Frant and J. W. Ross, Jr., AnaZ. Chem, , 40, 1169 (1968),

23. D. A. Shearer and G. F. Morris, Mierochem. J., 15, 199 (1970).

24. M. B. Terry and F. Kasler, Mikrochim. Acta, 1971, 569.

25. R. C. Rittner and T. S. Ma, Mikrochim. Acta, 1972, 404. 
26. W. Sel1g, Mikrochim. Acta, 1970, 337.

27. R. Belcher and A. M. G. MacDonald, Mikrochim. Acta, 1957, 510.

28. K. Hozumi and N. Akimoto, Jopan Analyst, 20, 467 (1971); through Analyt. Abstr., 23, No. 340 (1972).

29. G. J. Kakabadse, B. Manohin, J. M. Bather, E. C. Weller, and P. Woodbridge, Nature, 229, 626 (1971).

30. A. C. D. Newman, Analyst, 93, 827 (1968).

31. B. C. Jones, J. E. Heveran, and B. Z. Senkowski, J. Pharm. Sci., 60, 1036 (1971).

32. L. Helesic, Colt. Caech. Chem. Commun., 37, 1514 (1972).

33. S. S. M. Hassan, Mikrochim. Acta, 1974, 889.

34. B. Schreiber and R. W. Frei, Mikrochim. Acta, 1975 I, 219.

35. G. Gran, Analyst, 77, 661 (1952).

36. Orion Research Inc. Newsletter, 2, 49 (1970).

37. Orion Research, Inc., Newsletten, 3, 1 (1971).

38. W. Selig, Lawrence Livermore Laboratory, Livermore, Calif., Rept. UCRL51167 (1972); cf. Chem. Abstr., 77, 109154u (1972).

39. W. Sel1g, Mikrochim. Acta, 1973, 87.

40. J. W. Frazer, A. M. Kray, W. Selig, and R. Lim, Anal. Chem., 47, 869 (1975).

41. W. Sel1g, Mikrochim. Acta, 1974, 515 . 


\section{Sulfur}

A thorough treatment of the analysis of sulfur in organic compound is given in the monograph by Alicino et az. ${ }^{1}$ Organic sulfur may be converted to sulfate by oxidation, or to hydrogen sulfide by reduction. Both methods have been used in conjuction with ISE's. If oxidation is used, the sulfate is monitored with a lead ionselective Indicator electrode (Orion mode1 94-82 or equivalent) and a double-junction reference electrode (Orion mode1 90-92 or equivalent); if reduction is used, the sulfide is monitored with a silver sulfide ionselective indicator electrode (Orion mode1 94-16 or equivalent) and a single-junction reference electrode (0rion model 90-01 or equivalent).

Determination as Su?fate. A lead ISE has been commerctally avallable since 1969. It was used by Ross and Frant $^{2}$ for the potentiometric determination of endpoints in the direct titration of sulfate with standard lead solution. Selig ${ }^{3}$ used this electrode for the determination of micto and semimicro amounts of sulfate in organic compounds. Samples were decomposed by oxygen-flask combustion; the amount of sulfur ranged from 2 to $4 \mathrm{mg}$. Combustion products were absorbed in water containing $10 \mathrm{mg}$ of sodium nftrite. The excess of sodium nitrite and the carbon dioxide were expelled by botling.
The titrant was $0.01 \mathrm{M}$ lead perchlorate; the titration medium was $60 \%$ p-dioxane at $\mathrm{pH}$ of 4 to 6.5. The interference of fluoride was eliminated by adding boric acid or perchloric acid. Phosphate interfered and must be removed prior to the determination of sulfur.

Oxidation of the sulfur molety to sulfate. In organic compounds is usually accomplished by neutral or alkaline proxide. 1 Because the lead ISE is poisoned even by traces of pero:ide, sodium nitrite (recommended by Kirsten ${ }^{4,5}$, was used for the oxidation of sulfur. Addition of 10 to $15 \mathrm{mg}$ sodium nitrite was adequate for oxidation of at least $4 \mathrm{mg}$ of sulfur. Larger amounts of sodium nitrite increasingly reduced the endpoint potentials.

A medium of $60 \%$ p-dioxane was used $^{2}$ to suppress the solubility of lead sulfate. The effect of an increasingly nonaqueous medium is shown in Fig. 6 .

The recovery of sulfate was not strictly stoichlometric, as shown in Table 16. However, standardization of the titrant against $3 \mathrm{mg}$ sulfur ylelded good recoveries for 2 to $5 \mathrm{mg}$ of sulfur. The results for the analysis of seven compounds containing from 16 to $42 \%$ sulfur are shown in Table 17. The absolute error in sulfur content was less than $\pm 0.3 \%$; the 


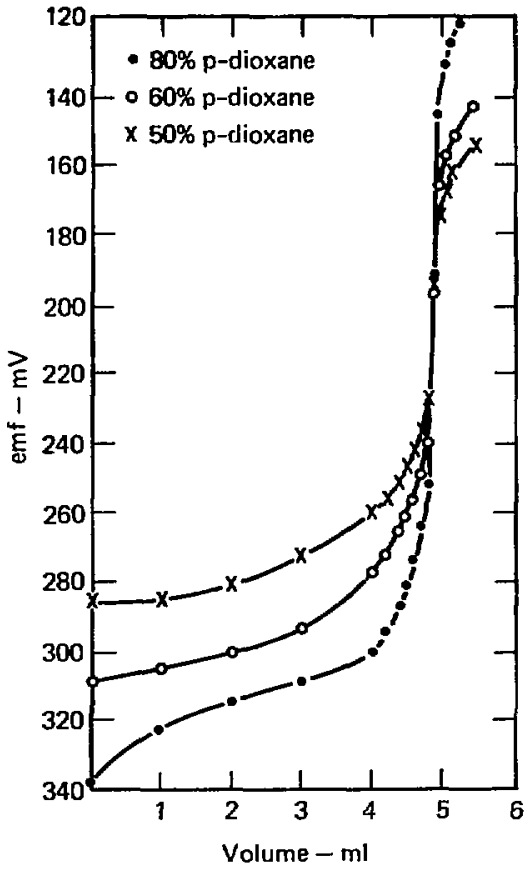

Fig. 6. Potentiometric titration of $1.5 \mathrm{mg}$ sulfur with $0.01 \mathrm{M}$ lead perchlorate. Source: Ref. 2, used with permission.

standard deviation of the absolute error was $0.07 \%$.

The effect of fluorine on the analysis of sulfur is shown in Table 18. In its presence, equilibrium potent1als were reached at a slower rate, endpoint breaks were slightly suppressed, and a positive bias of $0.3 \%$ was evident. Addition of a slightly greater than stoichiometric amount of borlc acld ${ }^{6}$ ( 1.1 times the amount of fluorine present) eliminated this
Table 16. Recovery of sulfur. ${ }^{a}$

\begin{tabular}{|c|c|c|c|}
\hline $\begin{array}{c}\text { Taken, } \\
\text { mg }\end{array}$ & $\begin{array}{c}\text { Recovered, } \\
\text { mg }\end{array}$ & $\begin{array}{c}\text { Recovery, } \\
\%\end{array}$ & $\begin{array}{c}\text { Mean, } \\
\%\end{array}$ \\
\hline 4.8119 & $\begin{array}{l}4.817 \\
4.814\end{array}$ & $\begin{array}{l}100.11 \\
100.04\end{array}$ & 100.08 \\
\hline 3.2079 & $\begin{array}{l}3.208 \\
3.208 \\
3.207 \\
3.206\end{array}$ & $\begin{array}{r}100.00 \\
100.00 \\
99.97 \\
99.94\end{array}$ & 99.98 \\
\hline 2.2455 & $\begin{array}{l}2.256 \\
2.248\end{array}$ & $\begin{array}{l}100.46 \\
100.11\end{array}$ & 100.29 \\
\hline 1.604 & $\begin{array}{l}1.627 \\
1.625 \\
1.626 \\
1.628\end{array}$ & $\begin{array}{l}101.43 \\
101.31 \\
101.37 \\
101.50\end{array}$ & 101.40 \\
\hline 1.2832 & $\begin{array}{l}1.326 \\
1.325\end{array}$ & $\begin{array}{l}103.3 \\
103.3\end{array}$ & 103.3 \\
\hline 0.9624 & $\begin{array}{l}9.994 \\
0.992\end{array}$ & $\begin{array}{l}103.3 \\
103.1\end{array}$ & 103.2 \\
\hline 0.6416 & $\begin{array}{l}0.689 \\
0.685\end{array}$ & $\begin{array}{l}107.4 \\
106.8\end{array}$ & 107.1 \\
\hline 0.3208 & 0.345 & 107.5 & \\
\hline 0.1604 & 0.179 & 111.6 & \\
\hline 0.0802 & 0.109 & 135.9 & \\
\hline
\end{tabular}

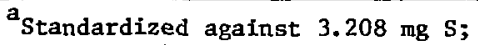
titrated with $0.01 \mathrm{M}$ lead perchlorate.

blas for 4-fluoro- 3-nitrophenyl sulfone and 4-fluorobenzenesulfonamide. If both fluorine and chlorine were present (as in p-fluorosulfonyl benezenesulfonyl chloride), even an elghtfold excess of borlc acid did not complex the fluorine. This was because of the formation of lead chlorofluoride, which, in the presence of 
Table 17. Analygis of sulfur in organic compounds.

\begin{tabular}{|c|c|c|c|c|}
\hline \multirow[b]{2}{*}{ Compound } & \multirow[b]{2}{*}{$\begin{array}{l}\text { Welght, } \\
\text { mg }\end{array}$} & \multicolumn{2}{|c|}{ Sulfur content } & \multirow[b]{2}{*}{$\begin{array}{c}\text { Error, } \\
\%\end{array}$} \\
\hline & & $\begin{array}{c}\text { Theory, } \\
z\end{array}$ & $\begin{array}{c}\text { Found, } \\
\%\end{array}$ & \\
\hline Phenyl thiourea $^{a}$ & $\begin{array}{l}13.000 \\
10.250 \\
13.850 \\
12.600\end{array}$ & 21.06 & $\begin{array}{l}21.00 \\
21.06 \\
21.05 \\
20.97\end{array}$ & $\begin{array}{r}-0.06 \\
0.00 \\
-0.01 \\
-0.09\end{array}$ \\
\hline $\begin{array}{l}\text { S-Benzyl thiturontum } \\
\text { chlorlde }\end{array}$ & $\begin{array}{l}17.000 \\
16.950 \\
19.300\end{array}$ & 15.82 & $\begin{array}{l}15.81 \\
15.83 \\
16.02\end{array}$ & $\begin{array}{l}-0.01 \\
+0.01 \\
+0.20\end{array}$ \\
\hline Sulfonal ${ }^{a}$ & $\begin{array}{r}8.550 \\
10.100 \\
9.050 \\
9.050\end{array}$ & 28.09 & $\begin{array}{l}27.98 \\
28.14 \\
28.34 \\
28.00\end{array}$ & $\begin{array}{l}-0.11 \\
+0.05 \\
+0.25 \\
-0.09\end{array}$ \\
\hline Sulfamic ac $i d^{a}$ & $\begin{array}{l}9.500 \\
9.450 \\
8.350\end{array}$ & 33.03 & $\begin{array}{l}33.13 \\
32.89 \\
32.87\end{array}$ & $\begin{array}{l}+0.10 \\
-0.14 \\
-0.16\end{array}$ \\
\hline Cystine & $\begin{array}{r}9.95 \\
11.10 \\
9.30\end{array}$ & 26.69 & $\begin{array}{l}26.59 \\
26.65 \\
26.59\end{array}$ & $\begin{array}{l}-0.10 \\
-0.04 \\
-0.10\end{array}$ \\
\hline Thiourea $^{c}$ & $\begin{array}{l}5.590 \\
6.152\end{array}$ & 42.12 & $\begin{array}{l}42.04 \\
42.16\end{array}$ & $\begin{array}{l}-0.08 \\
+0.04\end{array}$ \\
\hline Dibenzy1 disulfide ${ }^{a}$ & $\begin{array}{r}9.369 \\
10.196 \\
9.901\end{array}$ & 26.03 & $\begin{array}{l}26.04 \\
26.01 \\
26.04\end{array}$ & $\begin{array}{l}+0.01 \\
-0.02 \\
+0.01\end{array}$ \\
\hline
\end{tabular}

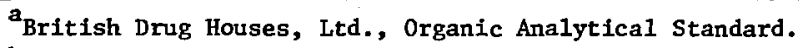

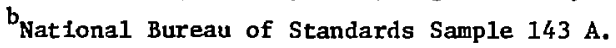

CAldrich Chentcal Co., Milwaukee, Wisc., puriss.
}

lead and chloride tons is even less soluble than lead sulfate. ${ }^{7}$ In this case, acidification with a few drops of $70 \%$ perchloric acid prior to boiling resulted in removal of the fluorine. The three flworine-containing compounds had fluorine contents varyIng from 7 to 11\%, and sulfur contents varying from 9 to $25 \%$.
Heistand and $\mathrm{Blake}^{8}$ have extended Selig's work to the determination of trace sulfur in petroleum products. Samples ylelding 10 to $100 \mu g$ sulfur were decomposed in a oxyhydrogen flame; products were absorbed in a solution containing $10 \mathrm{mg}$ sodium nitrite and $100 \mu \mathrm{g}$ sulfur (as sodiur sulfate). The excess nitrite was 
Table 18. Analysis of sulfur in the presence of fluorine.

\begin{tabular}{|c|c|c|c|c|c|}
\hline Compound & $\begin{array}{c}\text { Welght, } \\
\text { mg }\end{array}$ & $\begin{array}{c}\text { Sulfur } \\
\text { Theory, } \\
\%\end{array}$ & $\frac{\text { Ftent }}{\text { Found, }}$ & $\begin{array}{c}\text { Error, } \\
\%\end{array}$ & Remarks \\
\hline $\begin{array}{l}\text { 4-fluoro-3- } \\
\text { nit rophenyl } \\
\text { sulfone }\end{array}$ & $\begin{array}{l}26.350 \\
27.00 \\
29.35 \\
30.65 \\
25.15 \\
20.35 \\
28.80 \\
27.95 \\
34.30\end{array}$ & 9.31 & $\begin{array}{l}9.60 \\
9.65 \\
9.68 \\
9.40 \\
9.34 \\
9.33 \\
9.32 \\
9.30 \\
9.32\end{array}$ & $\begin{array}{l}+0.29 \\
+0.34 \\
+0.37 \\
+0.09 \\
+0.03 \\
+0.02 \\
+0.01 \\
-0.01 \\
+0.01\end{array}$ & $\begin{array}{l}\text { No boric acid added } \\
\text { No boric acid added } \\
\text { No boric acid added }\end{array}$ \\
\hline $\begin{array}{l}\text { 4-fluoro- } \\
\text { benzene- } \\
\text { sulfonamide }\end{array}$ & $\begin{array}{l}16.150 \\
17.900 \\
17.600\end{array}$ & 18.30 & $\begin{array}{l}18.30 \\
18.31 \\
18.25\end{array}$ & $\begin{array}{r}0.00 \\
+0.01 \\
-0.05\end{array}$ & \\
\hline $\begin{array}{l}\text { p-fluoro- } \\
\text { sulfonyl } \\
\text { benzene- } \\
\text { sulfony1 } \\
\text { chloride }\end{array}$ & $\begin{array}{l}9.200 \\
11.950 \\
10.25 \\
14.517 \\
11.800 \\
11.200 \\
10.550\end{array}$ & 24.79 & $\begin{array}{l}25.20 \\
25.10 \\
25.17 \\
24.94 \\
24.87 \\
24.81 \\
24.89\end{array}$ & $\begin{array}{l}+0.41 \\
+0.31 \\
+0.38 \\
+0.15 \\
+0.08 \\
+0.02 \\
+0.10\end{array}$ & $\begin{array}{l}\text { No additives }{ }^{d} \\
\text { No additives } \\
\text { Boric acid added } \\
2 \text { drops } \mathrm{HClO}_{4} \text { added } \\
3 \text { drops } \mathrm{HClO}_{4} \text { added } \\
3 \text { drops } \mathrm{HClO}_{4} \text { added } \\
4 \text { drops } \mathrm{HClO}_{4}^{4} \text { added }\end{array}$ \\
\hline
\end{tabular}

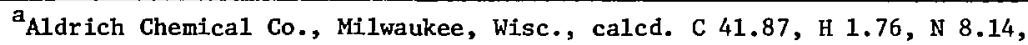
F 11.04; found C 41.81, H 1.56, N 8.13, F 10.98 .

bAldrich Chemical Co., Milwaukee, Wisc., calcd. C 41.14, H 3.45, N 8.00, F 10.84; found C 40.87, H 3.41, N 8.06, F 10.79 .

'Aldrich Chemical Co., Milwaukee, Wisc., calcd. C 27.86, H 1.56, C1 13.71, F 7.34; found C 27.86, H 1.69, C1 13.60, F 7.24.

${ }^{d}$ values not included in calcr'ation of standard deviation.

destroyed by bolling. The titrant was $0.0025 \mathrm{M}$ lead perchlorate; the titration medium was $50 \%$ in p-dioxane. A polarization current of 0.5 uamp was applied through the lead ISE. The passage of this polarization current through the system was necessary to obtain a signiflcant potential break. The effect of the polarization current on the endpoint break is shown in FIg. 7. Since endpoints were obscure and results poor whenever the sulfate level dropped below $100 \mu g$ sulfur (probably due to the solubility of lead sulfate) this amount of sulfur (as sodium sulfate) was always added to the absorbing solution. The nonstoichlometry observed by $\operatorname{Selig}^{3}$ was not evident below $100 \mu \mathrm{g}$ sulfur. Helstand and 


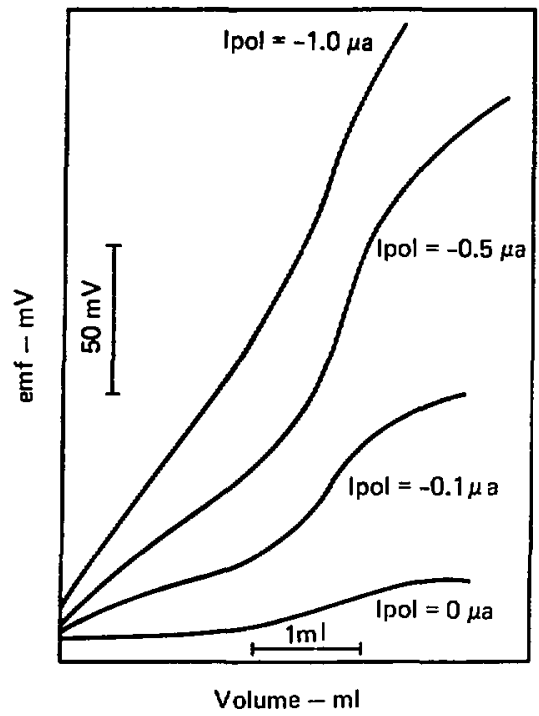

Fig. 7. Effect of polarization current on $\mathrm{Pb}^{++}$ISE endpoint. Source: Ref. 8, used with permission.

Blake believe thetr method superior to the previously used barium turbidimetric fiulsh for determining sulfur In petroleum products.

Harzdorf ${ }^{9}$ has found that the lead ISE responds not only to lead but also to sulfate. Although the response is non-Nernstian this ISE may be used as the indicating electrode in potentiometric titrations. Organic samples were decomposed in an oxygen-flask or In an oxyhydrogen flame. Combustion products were absorbed in $10 \mathrm{ml}$ water and $0.5 \mathrm{ml} 1 M$ sodium hydroxide plus 2 drops of hydrogen peroxide. The excess of peroxide was destroyed by bolling for $15 \mathrm{~min}$ and 1ts complete removal assured by addition of 2 to 3 drops of $2 \%$ hydrazine hydrate. Then $1 M$ perchlortc acld was added and carbon dioxide was removed by boiling. The titrant was $0.01 \mathrm{M}$ barlum perchlorate; the titration medium was $70 \%$ dioxane at $\mathrm{pH} 7$, Since the solubility product of barlum sulfate fs lower by two orciers of magnitude than that of lead sulfate, the advantage of the barium titrant is obvious. No data were presented by Harzdorf.

Small endpoint breaks have been observed occasionally in the titration of sulfate in a medium containing dioxane. 10 They have been attributed to traces of an "unknown" Impurity in some batches of dioxane. Selig ${ }^{11}$ found that freshly-opened bottles of non-stabllized dioxane yielded good endpoint breaks. However, further use of the same bottle yielded increasingly poor titration curves. This is due to the formation of peroxides. The problem can be avoided by using methanol or ethanol as the nonaqueous component. The slight loss in sensitivity can be overcome by using a larger percentage of the nonaqueous component. ${ }^{11}$

Determination as Sulfide. Slanina et $a l^{12}$ have automated the determination of 5 to $-70 \mu g$ sulfur in organic compounds. The sulfur was reduced to hydrogen sulfide, which was titrated wth a lead solution. Endpoints were 
detected wht a H1ver aulfide ISE. The autc zatic titrator has a mV controller ihat activates the titrant delivery pump if the signal of the $\mathrm{pH}$ meter exceeds the set-point. In this way, the added sulfide is titrated to a constant sulfide concentration. The $\mathrm{mV}$ controller is equipped with a proportional band of $3 \mathrm{mV}$ to avold overshoot. The optimum set-point depends on the proportional band of the $\mathrm{mV}$ controller, the pump rate, and concentration of titrant. Slanina et al. ${ }^{12}$ found that for a proportional band of $3 \mathrm{mV}$, a pump rate of $70 \mu \mathrm{g} /$ $\mathrm{min}$, and a concentration of $0.01 \mathrm{M}$ lead, the best set-point was near $800 \mathrm{mV}$ relative to a saturated calomel electrode (SCE).

Samples were reduced by hydrogen (100 ml/min flow rate) over a platinum catalyst at $900^{\circ} \mathrm{C}$ within $4 \mathrm{mIn}$. The reduction apparatus was connected directly with the titration vessel, which was swept with nitrogen to exclude air.

The absorbing solution consisted of $4 M$ potassium hydroxide and $I M$ hydroxylamine. The titrant was $0.01 \mathrm{M}$ lead nitrate (it takes two days for the titrant to stabllize at $\mathrm{pH} 2$ ). The sulfide solution was $0.035 \mathrm{M}$ at pH 14. About $100 \mu 1$ of this solution was added to the absorbing solution, the optimum potential for the $\mathrm{mV}$ controller was selected and the sidfide was t1trated.
Thirty seconds after the beginning of combustion, the first hydrogen sulfide appears in the titration vasse1. The titration is completed after about $8 \mathrm{~min}$. The whole cycle thus takes about $10 \mathrm{~min}$. Results of some determinations are shown in Table 19. The standard deviation for a11 determinations was $0.14 \%$ absolute, or $0.7 \%$ relative. Sulfate, chloride, todtde, and cyanide did not Interfere.

This procedure was extended in a later paper ${ }^{13}$ to the automated determination of traces of sulfur in organic compounds. Only small changes were made in the original procedure. Samples contained 100 to 500 ppm of sulfur. The titrant was a $0.0002 M$ lead (II) solution. Samples were hydrogenated in a wide tube in a stream of hydrogen at $1050^{\circ} \mathrm{C}$ over quartz wool. Titrations were carried out automatically until the preset signal of a stlver sulfide ISE was reached. Total analysis time was about 5 to $6 \mathrm{~min}$. For samples containing more than 5 ppm of sulfur, the standard deviation was less than $3 \%$ relative to the mean value. Nitrogen compounds Interfere only if present in large amounts.

Volodina and Martynova ${ }^{14}$ determined sulfur in organic compounds by pyrolysis in a stream of ammonia in a quartz tube at $800^{\circ} \mathrm{C}$. The absorbing solution was $1 M$ potassium hydroxide containfing $5 \%$ glycerol as antioxidant. 
Table 19. Microanalysis of some organlc sulfur compounds.

\begin{tabular}{|c|c|c|c|c|c|}
\hline Compound & $\begin{array}{l}\text { Max sample, } \\
\text { mg }\end{array}$ & $\begin{array}{l}\text { No. of } \\
\text { Determin- } \\
\text { ations }\end{array}$ & $\begin{array}{c}\text { Sulfu } \\
\begin{array}{c}\text { Theory, } \\
\%\end{array}\end{array}$ & $\frac{\text { ntent }}{\text { Found, }}$ & $\begin{array}{l}\text { Abs } \\
\text { std } \\
\text { dev. }\end{array}$ \\
\hline $\begin{array}{l}\text { Sulphonal (B.D.H. } \\
\text { standard) }\end{array}$ & 520 & 12 & 28.09 & $28.0_{7}$ & $0.1_{7}$ \\
\hline $\begin{array}{l}\text { Sulphamic acid } \\
\text { (B.D.H. standard) }\end{array}$ & 650 & 13 & 33.03 & $33.0_{8}$ & $0.1_{9}$ \\
\hline $\begin{array}{l}\mathrm{C}_{18} \mathrm{H}_{30} \mathrm{O}_{4} \mathrm{SI} \\
\text { blochemical prep. }\end{array}$ & 1000 & 6 & 6.83 & $6.7_{3}$ & $0.0_{8}$ \\
\hline $\begin{array}{l}\mathrm{C}_{24} \mathrm{H}_{26} \mathrm{O}_{7} \mathrm{~S}_{2} \\
\text { biochemical prep. } \\
\text { (Impure) }\end{array}$ & 1100 & 4 & $\begin{array}{l}\text { ca. } \\
13.7\end{array}$ & 13.36 & $0.1_{5}$ \\
\hline $\begin{array}{l}\text { Propy1propargy1 } \\
\text { sulfide (prep.) }\end{array}$ & 1000 & 8 & 28.07 & $28.0_{4}$ & $0.1_{5}$ \\
\hline $\begin{array}{l}\text { Methionine (B.D.H. } \\
\text { analar) }\end{array}$ & 400 & 4 & 21.49 & 21.49 & $0.0_{8}$ \\
\hline Dihexylsulphone & 600 & 4 & 13.68 & $13.5_{6}$ & 0.0 \\
\hline $\begin{array}{l}\text { Trimethylsulphonium } \\
\text { lod1de }\end{array}$ & 800 & 6 & 15.71 & $15.7_{3}$ & $0.0_{5}$ \\
\hline Ethy1hexy1sulphone & 550 & 6 & 17.98 & $17.9_{0}$ & $0.2_{3}$ \\
\hline $\begin{array}{l}\text { S-benzylthiouronium } \\
\text { chloride (B.D.H. } \\
\text { standard) }\end{array}$ & 400 & 4 & 15.82 & 15.89 & $0.1_{6}$ \\
\hline $\begin{array}{l}\text { Benzy 1 sulphide } \\
\text { (B.D.H. standard) }\end{array}$ & 500 & 7 & 26.04 & $25.9_{3}$ & $0.0_{9}$ \\
\hline $\begin{array}{l}\text { Unsaturated mercaptan- } \\
\text { tan }\end{array}$ & 550 & 6 & Unknown & $17.9_{8}$ & $0.1_{1}$ \\
\hline
\end{tabular}

The sample size was 3 to $5 \mathrm{mg}$. Samples were pyrolyzed for $10 \mathrm{~min}$ while ammonla was passed through the apparatus at $10 \mathrm{ml} / \mathrm{min}$. The contents of the absorption vessels were then titrated potentiometrically with $0.01 M$ ammoniacal silver nitrate.
Emf's were monitored with a silver sufide ISE and an SCE. The results for several compounds are shown in Table 20. It is noteworthy that these compounds all contain only divalent sulfur in moleties such as = CS, C-S-S-C, C-S-C, and -SH. The 
Table 20. Determination of sulfur in organic compounds. ${ }^{a}$

\begin{tabular}{|c|c|c|c|c|}
\hline \multirow[b]{2}{*}{ Compound } & \multirow[b]{2}{*}{$\begin{array}{c}\text { Welght, } \\
\mathrm{mg}\end{array}$} & \multicolumn{2}{|c|}{ Sulfur content } & \multirow[b]{2}{*}{$\begin{array}{c}\text { abs exror, } \\
\%\end{array}$} \\
\hline & & $\begin{array}{c}\text { Found, } \\
\%\end{array}$ & $\begin{array}{c}\text { Theory, } \\
\%\end{array}$ & \\
\hline 2-Mercaptothiazoline & $\begin{array}{l}3.030 \\
3.090\end{array}$ & $\begin{array}{l}53.76 \\
54.03\end{array}$ & 53.79 & $\begin{array}{l}-0.03 \\
+0.24\end{array}$ \\
\hline Dibenzyl disulfide ${ }^{a}$ & $\begin{array}{l}4.970 \\
5.470\end{array}$ & $\begin{array}{l}25.87 \\
26.18\end{array}$ & 25.99 & $\begin{array}{l}-0.12 \\
+0.19\end{array}$ \\
\hline Thioacetanilide & $\begin{array}{l}4.665 \\
3.810\end{array}$ & $\begin{array}{l}21.03 \\
21.00\end{array}$ & 21.20 & $\begin{array}{l}-0.17 \\
-0.20\end{array}$ \\
\hline Thiosemicarbazide & $\begin{array}{l}4.580 \\
4.420\end{array}$ & $\begin{array}{l}35.01 \\
35.50\end{array}$ & 35.22 & $\begin{array}{l}-0.21 \\
+0.28\end{array}$ \\
\hline 2,2-Benzthiazy1 disulfide & $\begin{array}{l}3.650 \\
4.950\end{array}$ & $\begin{array}{l}38.74 \\
27.35\end{array}$ & 38.57 & $\begin{array}{l}+0.17 \\
-0.23\end{array}$ \\
\hline N-A1lylthiourea & $\begin{array}{l}5.180 \\
4.950\end{array}$ & $\begin{array}{l}27.46 \\
27.35\end{array}$ & 27.58 & $\begin{array}{l}-0.12 \\
-0.23\end{array}$ \\
\hline Diphenyl disulfide ${ }^{a}$ & $\begin{array}{l}5.010 \\
5.050\end{array}$ & $\begin{array}{l}29.03 \\
29.14\end{array}$ & 29.37 & $\begin{array}{l}-0.34 \\
-0.23\end{array}$ \\
\hline Thiourea & $\begin{array}{l}3.030 \\
3.060\end{array}$ & $\begin{array}{l}42.32 \\
42.46\end{array}$ & 42.12 & $\begin{array}{l}+0.20 \\
+0.34\end{array}$ \\
\hline
\end{tabular}

an error In Table 1 of the English tralslation of this paper should be pointed out: dibenzyl sulfide and dipheny1 sulfide should be dibenzyl disulfide and diphenyl disulfide.

absolute error was \%0.3\%. A single determination took approximately 20 min.
A summary of the more important methods for the determination of sulfur in organic compounds using ISE's

Table 21. Summary of methods for sulfur in organic compounds using ISE's.

\begin{tabular}{|c|c|c|c|c|c|c|}
\hline Reference & $\begin{array}{l}\text { Method of } \\
\text { decomposition }\end{array}$ & $\begin{array}{l}\text { Absorbing } \\
\text { nediun }\end{array}$ & $\begin{array}{l}\text { Ind icator } \\
\text { electrode }\end{array}$ & Titrant & $\begin{array}{l}\text { Titration } \\
\text { medium }\end{array}$ & Interferences \\
\hline 3 & oxygen-flank & Water + $\mathrm{NaNO}_{2}$ & Lead & $\begin{array}{l}0.01 \mathrm{M} \text { lead } \\
\text { perchlorate }\end{array}$ & $\begin{array}{l}60 \% \text { dioxane } \\
\mathrm{pH} 4-6.5\end{array}$ & Phosphate \\
\hline 12 & $\begin{array}{l}\text { Reduction by } \\
\mathrm{H}_{2} \text { over Pt }\end{array}$ & $4 \mathrm{H} \mathrm{KOH}+\mathrm{H} \mathrm{NH}_{2} \mathrm{OH}$ & $\mathrm{Ag}_{2} \mathrm{~S}$ & $\begin{array}{l}0.02 / \text { lead } \\
\text { nitrate }\end{array}$ & $\begin{array}{l}\text { Absorblng } \\
\text { solution }\end{array}$ & \\
\hline 14 & $\begin{array}{l}\text { Reduction by } \\
\text { amonia }\end{array}$ & $N$ ROH & $\mathrm{Ag}_{2} \mathrm{~S}$ & $\begin{array}{l}0 . \mathrm{OLM}^{\mathrm{M}} \text { ammoniacal } \\
\mathrm{AgNO}_{3}\end{array}$ & $\begin{array}{l}\text { Absorbtng } \\
\text { solutton }\end{array}$ & \\
\hline 9 & $\begin{array}{l}\text { Oxygen-flask } \\
\text { or oxyhydrogen } \\
\text { flawe }\end{array}$ & $\mathrm{NaOH}+\mathrm{H}_{2} \mathrm{O}_{2}$ & lead & $\begin{array}{l}0.0 \mathrm{M} \text { barfun } \\
\text { perchlorate }\end{array}$ & $\begin{array}{l}70 z \text { dioxane } \\
\text { pH } 7\end{array}$ & No data \\
\hline
\end{tabular}


is given in Table 21. The sulfur was converted elther by oxidation to sulfate (oxygen-flask or oxyhydrogen flame) or by reduction to hydrogen sulfide (by hydrogen or ammonia at high temperature). The method of finish was by potentiometric titration in all cases. A lead ISE was used to monitor the titration of sulfate with lead or barium perchlorate; a silver sulfide ISE was used to monitor the titration of sulfide with lead nitrate or ammoniacal silver nitrate.

\section{References}

1. J. F. Alicino, A. I. Cohen, and M. E. Everhard, "Organic Analysis: SulFur," in Treatise on Analytical Chemistry, Part II, Vo1. 12, I. M. Kolthoff and P. J. Elving, Eds. (Interscience, New York, 1965), p. 57.

2. J. W. Ross, Jr., and M. S. Frant, AnaZ. Chem., 41, 967 (1969).

3. w. Selig, Mikrochim. Acta, 1970, 168.

4. W. Kirsten, Mikrochim. Acta, 1960, 272.

5. W. J. Kirsten, K. Hansson, and S. K. Nilsson. Analyt. Chim. Aata, 28, 101 (1963).

6. R. Belcher and A. M. G. MacDonald, Talanta, 1, 185 (1958).

7. C. A. Horton, in Treatise on Analytical Chemistry, Part II, VoI. 7, I. M. Kolthoff and P. J. Elving, Eds. (Interscience, New York, 1961), P. 257.

8. R. N. Heistand and C. T. Blake, Mikrochim. Acta, 1972, 212.

9. C. Harzdorf, Z. AnaZ. Chem., 262, 167 (1972).

10. Orion Research Inc., Newsietter, 3, 27 (1971).

11. W. Selig and A. Salomon, Mikrochim. Acta, 1974, 663.

12. J. Slanina, J. Agterdenbos, and B. Griepink, Mikrochim. Acta, 1970, 1225.

13. J. Slanina, P. Vermeer, J. Agterdenbos, and B. Griepink, Mikrochim. Acta, $1973,607$.

14. M. A. Volodina and G. A. Martynova, Zh. Analit. Khim., 26, 1002 (1971); through J. Anat. Chem. USSR, 26, 896 (1971). 


\section{Halegew}

A thorough treatment of the analysis of halides in organic compounds is given in the monograph by Olson. ${ }^{1}$ Nonionic halogen is usually converted to halide by combustion of the compound in oxygen, either in a closed flask, or In a tube over a catalyst. The resulting halide has been most frequentiy monitored with a silver sulfide ion-selective indicator electrode (Orion model 94-16 or equivalent); however, the individual halide electrodes (Orfon models 94-17, 94-35, and 94-53 or equivalent) may also be used.

Krijgsman and co-workers ${ }^{2,3}$ have automated the determination of microgram amounts of halogen in organic compounds. The combustion chamber, measuring apparatus, and electronic circuitry are similar to that described by Slanina at az. ${ }^{4}$ for the determination of sulfur in organic compounds. The mV controller was equipped with a proportional band of $4 \mathrm{mV}$; the pump rate was $70 \mu \mathrm{I} / \mathrm{min}$. The absorbing solution was saturated prior to starting the first determination by dissolving $10 \mu \mathrm{g}$ halide and titrating to the predetermined emf. This emf was $300 \mathrm{mV}$ relative to the reference electrode for chloride and $210 \mathrm{mV}$ for bromide and todtde.

Between 0.1 and 10 pequiv of halogen could be determined in a sample of 10 to $500 \mu \mathrm{g}$. The procedure is simllar to that previouly described for the determination of halide ir. an inorganic matrix. ${ }^{5}$ Samples were burned in a tube in a stream of oxygen at 900 to $1000^{\circ} \mathrm{C}$ over platinum, palladium, and quartz. The gaseous combustion products were absorbed in $80 \%$ acetic acid containing $1 \%$ hydrogen peroxide and $1 \%$ hydrazine. The latter speeds up the titration of lodide and improves the results of this titration. Halides were automatically titrated with $0.003 \mathrm{M}$ silver nitrate using a silver sulfide ISE. One determination took approximately 3 to 6 min. The results for several compounds are shown in Table 22. The standard deviation was less than $0.35 \%$ absolute. Sulfur, nitrogen, phosphorus, and arsenic did rot interfere.

In another paper Krijgsman et $a z^{3}$ described an automated procedure for the determination of chlorine in organic compounds. The equipment and procedures were essentially the same as described above. ${ }^{2}$ The method was sultable for 5 to $100 \mu g$ of chlortne. The absorbing and titration medium consisted of $75 \%$ acetic actd and $1 \%$ hydrogen peroxide; the titrant was $0.01 \mathrm{M}$ silver nitrate. One determination took approximately 5 min. A small amount of stearic acid was added as a combustion aid to highly chlorinated compounds such as hexachlorobenzene. For such compounds, 
Table 22. Results of halogen analysis in organic compounds.

\begin{tabular}{|c|c|c|c|c|}
\hline Compound & $\begin{array}{l}\text { No. of } \\
\text { deter- } \\
\text { minations }\end{array}$ & $\begin{array}{c}\text { Haloge } \\
\text { Theory, } \\
\%\end{array}$ & $\begin{array}{c}\text { ntent } \\
\text { Found, } \\
\%\end{array}$ & $\begin{array}{c}\text { Abs std } \\
\text { dev, } \\
\%\end{array}$ \\
\hline p-Chlorobenzolc actd & 10 & 22.65 & 22.64 & 0.33 \\
\hline $\begin{array}{l}\text { S-benzylthiuronium- } \\
\text { chloride }\end{array}$ & 10 & 17.49 & 17.48 & 0.21 \\
\hline Hexachlorobenzene & 5 & 74.70 & 74.55 & 0.35 \\
\hline $\begin{array}{l}\text { 1-Chloro-2,4-dinicro- } \\
\text { benzene }\end{array}$ & 9 & 17.50 & 17.44 & 0.17 \\
\hline Phospholiptd (prep.) & 3 & - & 1.45 & 0.10 \\
\hline o-Iodobenzolc acid & 9 & 51.17 & 51.17 & 0.32 \\
\hline Octadecy1 Lodide & 5 & - & 31.86 & 0.47 \\
\hline$\alpha$-Iodostearic acid & 6 & - & 30.55 & 0.56 \\
\hline $\mathrm{p}-$ Bromobenzoic acid & 10 & 39.75 & 39.75 & 0.38 \\
\hline $\begin{array}{l}\alpha \text {-bromooctadecyl- } \\
\text { succinic acid }\end{array}$ & 6 & 18.36 & 18.25 & 0.13 \\
\hline $\begin{array}{l}\text { Dimethyldibromo- } \\
\text { succinic acid }\end{array}$ & 8 & 52.27 & 51.61 & 0.39 \\
\hline Bromothymolblue & 4 & 25.60 & 26.28 & 0.25 \\
\hline
\end{tabular}

the palladium in the furnace promotes hydrogenation of the nascent chlorine. Borate, fluoride, arsenate, and phosphate did not interfere. The interference of hydrogen sulflde was eliminated by adding cadmium acetate to the absorbing solution. The standard deviation was approximately $0.3 \%$ absolute.

Potman and Dahmen ${ }^{6}$ have modified the procedures of Krijgsman et $a z^{2}{ }^{2,3}$ and applied them to the determination of chlorine and bromine in volatile organic compounds. The combustion system was similar to the one described above. The number of $\mu \mathrm{g}$ samples that could be determined consecutively in the procedures of Krijgsman is limited because silver halide precipitates were formed that tend to adsorb halide. Therefore the titration was modified: the absorption solution (and hence the titration medium) consisted of $80 \%$ acetic acid containing $1.2 \%$ hydrogen peroxide, $1.5 \%$ nitric acid, and $0.14 \%$ mercurlc chloride or bromide. The titrant was $0.05 N$ mercuric lon, prepared by 
dissolving mercurfc oxide in a mixture of $80 \%$ acetic acid, $5 \%$ nitric acfd, and $15 \%$ water. Samples were introduced into the combustion system by hypodermic syringe and burned at $1000^{\circ} \mathrm{C}$ over platinum and quartz in a stream of oxygen.

The potentiometric set-point was $270 \mathrm{mV}$ for both chloride and bromide determinations. During the titration, the titrant was added so that the emf was held within $\pm 10 \mathrm{mV}$ of the setpoint. In this way, equilibrium potentlals were reached more rapidly. A titration was considered complete when no more than $0.1 \mu \mathrm{I} / \mathrm{min}$ of titrant had to be added. Since the statility of the set-point depended on the amount of water, the latter should remain nearly constant.
The silver sulfide ISE was found to be reversible as long as the mercuric ion concentration did not exceed I $\mathrm{m} W$. Nitric acid was required in the absorption solution and in the titrant in order to prevent the precipitation of mercuric salts. Reducing agents stronger than hydrogen peroxide could not be used in the absorbing solution, since mercuric Ion would then also be reduced. Furthermore, if the concentration of hydrogen peroxide exceeds $1.2 \%(\mathrm{v} / \mathrm{v})$, the sulfide in the silver sulfide crystal of the electrode will be oxidized. Some results are shown in Table 23. One determination required about $15 \mathrm{~min}$; the relative standard deviation was about $1 \%$. Sample size varied from 1 to $4 \mathrm{mg}$.

Table 23. Determination of halogens in volatile organic compounds.

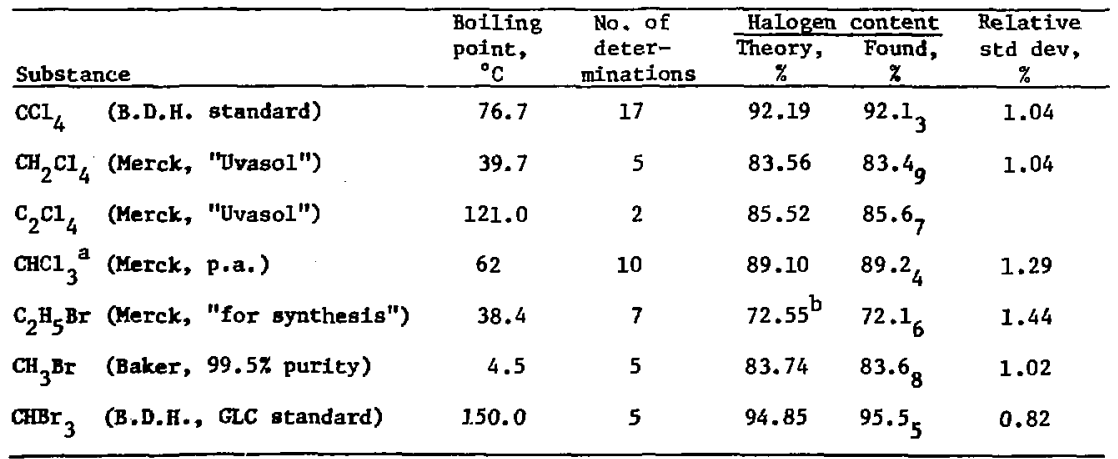

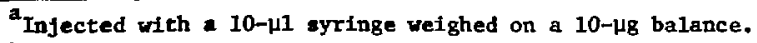

betermined by the Schöniger flask method. 
Experiments were periormed to clarify the mechanism of the interaction of mercuric fon with the silver sulfide electrode. A one-electron Nerstlan slope of $60 \mathrm{mV}$ was observed with mercuric ions, which can be explained by the assumption that the following 1on-exchange process occurs on the surface of the silver sulfide crystal :

$$
\begin{aligned}
& \mathrm{Hg}^{2+}+\mathrm{Ag}_{2} \mathrm{~S} \text { (crystal) } \\
& \quad{ }_{(\text {AgHgS })^{+}}(\text {crystal })+\mathrm{Ag}^{+} .
\end{aligned}
$$

The presence of mercury on the suriace of a silver suifide crystal was confirmed by $x$-ray fluorescence measurements. The mercury response disappears when the crystal is polished with emery paper.

Crossman and $\mathrm{Sel}_{\mathrm{g}}{ }^{7}$ have analyzed small amounts of a chlorine-containing plasticizer, tris ( $\beta$-chloroethy1 phosphate), in high explosives. Samples containing up to $1 \mathrm{~g}$ of the explosive were burned in an oxygen-bomb. The absorbing solution was water or $0.1 \mathrm{M}$ sodium hydroxide. The titration medIum was aqueous; the titrant was $0.05 \mathrm{M}$ silver nitrate. The endpoint breaks can be enhanced by using a partially alcoholic medium. The potentionetric titration of the chlorlde was monttored with a chloride ISE. In a subsequent paper, Sel1g 8 recomended the use of mercuric perchlorate for the potentiometric titration of halides. This titrant may be convenient1y stored in a reservolr-type buret. It has been found more stable than the mercuric nitrate recommended by Harzdorf. 9 The method can also be applied to the determination of a variety of halogen-containing organtc compounds after combustion in an oxygen-flask or by other means.

Hassan $^{10}$ determined chlorine and bromine in some organic compounds after combustion in an oxygen-flask. The gaseous products were absorbed in alkaline hydrogen peroxide. The halldes were titrated in $50 \%$ dioxane at $\mathrm{pH} 5$ to 7 with $0.02 \mathrm{M}$ silver nitrate. The results for some chlorine-containing compounds are shown in Table 24 and for some

Table 24. Potentiometric determination of some chlorine con-

\begin{tabular}{|c|c|c|c|}
\hline Compound & $\begin{array}{c}\text { Chlorine } \\
\text { Theory, } \\
\end{array}$ & content & $\begin{array}{c}\text { Recovery, } \\
\bar{z}\end{array}$ \\
\hline 1-Chloroanthraquinone & 14.64 & $\begin{array}{l}14.7 \\
14.5 \\
14.6\end{array}$ & $\begin{array}{r}100.4 \\
99.0 \\
99.7\end{array}$ \\
\hline 4-Chlorobezzophenone & 16.38 & $\begin{array}{l}16.4 \\
16.4 \\
16.3\end{array}$ & $\begin{array}{r}100.1 \\
100.1 \\
99.5\end{array}$ \\
\hline $\begin{array}{l}\text { 2,4-D1chlorobenzo- } \\
\text { phenone }\end{array}$ & 28.28 & $\begin{array}{l}28.0 \\
28.0 \\
27.9\end{array}$ & $\begin{array}{l}99.0 \\
99.0 \\
98.7\end{array}$ \\
\hline Chloranfl & 57.72 & $\begin{array}{l}57.5 \\
57.8 \\
57.6\end{array}$ & $\begin{array}{r}99.6 \\
100.1 \\
99.8\end{array}$ \\
\hline Perchloroethane & 89.98 & $\begin{array}{l}89.7 \\
89.7 \\
89.8\end{array}$ & $\begin{array}{l}99.7 \\
99.7 \\
99.8\end{array}$ \\
\hline
\end{tabular}
taining compounds. 
bromine-containing compounds In Table 25. They were accurate to $\pm 0.3 \%$ absolute.

Paletta and Panzenbeck ${ }^{11}$ determined lodine in some organtc compounds and biological materials by direct measurement of the lodfde concentration with an iodide ISE after decomposition. Samples were decomposed by reduction at $60^{\circ} \mathrm{C}$ for 10 min with aluminum foil in alkaline solution (pH 11). The cooled samples were neutralized with hydrochloric acid and the emf was measured directly. Calibration standards of sodium iodide were also subjected to reduction and neutralization in the same fashion. The concentration range of interest was $10^{-7}$ to $10^{-9} \mathrm{~g} / \mathrm{ml}$ iodine. The compounds Investigated were $3,3,5^{\prime}$-trijodo-I-thyronine and $3,3^{\prime}, 5,5^{\prime}$-tetraiodo-L-thyronine (thyroxin). Good agreement with the standard thlosulfate method was obtained on a sample of liver bile. Papp and Pungor 12,13 determined chloride in the chloride salts of some drugs using a chloride ISE. For the direct measurement of the chloride concentration, the electrode was conditioned for 2 to $3 \mathrm{~h}$ in $10^{-3} \mathrm{M}$ potasslum chloride. Callbration curves covered the range of $10^{-4}$ to $10^{-1} M$. The Ionic strengths of standards and samples were kept constant with $0.1 M$ potassium nitrate. Samples were determined in aqueous solution.
Table 25. Potentiometric determination of some bromine containing compounds.

\begin{tabular}{|c|c|c|c|}
\hline \multirow[b]{2}{*}{ Compound } & \multicolumn{2}{|c|}{ Bromine } & \multirow[b]{2}{*}{ Recovery, } \\
\hline & $\begin{array}{c}\text { Theory, } \\
\%\end{array}$ & $\begin{array}{c}\text { Found, } \\
\%\end{array}$ & \\
\hline Bromanil & 75.47 & $\begin{array}{l}75.2 \\
75.2 \\
75.1\end{array}$ & $\begin{array}{l}99.6 \\
99.6 \\
99.5\end{array}$ \\
\hline $\begin{array}{l}\text { Tetrabromophthallc } \\
\text { anhydride }\end{array}$ & 68.96 & $\begin{array}{l}69.0 \\
69.0 \\
68.7\end{array}$ & $\begin{array}{r}100.1 \\
100.1 \\
99.6\end{array}$ \\
\hline $\mathrm{p}$-Bromobenzoic actd & 39.80 & $\begin{array}{l}39.8 \\
39.8 \\
39.8\end{array}$ & $\begin{array}{l}100.0 \\
100.0 \\
100.0\end{array}$ \\
\hline $\begin{array}{l}\text { Tetrapropy } 1 \\
\text { ammontum bromide }\end{array}$ & 30.07 & $\begin{array}{l}30.0 \\
30.3 \\
30.2\end{array}$ & $\begin{array}{r}99.8 \\
100.8 \\
100.4\end{array}$ \\
\hline $\begin{array}{l}\text { Tetraheptyl } \\
\text { ammonium bromide }\end{array}$ & 16.46 & $\begin{array}{l}16.6 \\
16.4 \\
16.4\end{array}$ & $\begin{array}{r}100.8 \\
99.6 \\
99.6\end{array}$ \\
\hline
\end{tabular}

The accuracy of the method was $\pm 0.05 \%$ Cl. For more accurate measurements, potentiometric titrations were preferred.

In another paper, Pungor et az. 14 discuss in detail the determination of halogen in organic compounds. Ionic halides such as hydrochlorides were determined directly in aqueous solution. Covalently-bound halide was determined after oxygen-flask combustion. ISE's were conditioned in $0.1 M$ solutions of the appropriate electrolytes and kept in this solution between measurements. A relatively simple method for determining the mean activity coefflcient of large organfc molecules is given. In our opinton, however, using a TISAB elimInates this problem.

Dessouky et al. ${ }^{15}$ determined 24 pharmaceuticals by both direct and 
indirect potentionetric methods. As above, 14 dissociated halides were determined directly; covalently-bound halide, after oxygen-flask combustion. The solutions were neutralized after combustion with $2 M$ nitric actd to the methyl red endpoint and diluted to a known volume. The Ionic strength was calculated and adjusted to that of the standards, which were maintained at $0.1 M$ by means of sodium nitrate. Again, the use of a TISAB would eliminate the necessity of calculating the ionic strength. The compounds investigated fall into the following groups:

Group A: Medical dyes.

Group B: Anticancer or cytostatic compounds.

Group C: Antibiotics.

Group D: Official pharmaceutical compounds whose molecules contain both dissoclated and undissociated halogen.

Group E: Official pharmaceutical compounds whose molecules contain both dissociated and undissoclated different halogens.

Group F: Offlcial pharmaceutical compounds containing only undissoclated halogen.

Group G: Offictal pharmaceutical compounds containing undissoctated different halogens.

Group H: Miscellaneous pharmaceutlcal compounds.
The ISE's were pretreated before use in $10^{-3} \mathrm{M}$ solutions of the appropriate hallde. For compounds containing lodine and chlorine, lodine was first determined using an fodide ISE without interference from the chlortde. Before the determination of chloride, the lodide had to be completely removed or deactivated. This was accomplished by taking a suitable aliguot, acidifying with nitric acid, and adding permanganate solution until the solution began to turn pink. The solution was then neutralized with potassium hydroxide and diluted to volume; the chloride content was measured with a chloride ISE. The values were not as accurate as those obtained by potentiometric titration; they were, however, within 2 to $3 \%$ of these values. Potentiometric titrations were carried out with standard silver nitrate in a slightly acid solution. If the solution contained more than one halide ion, e.g. chloride and iodide, the titrations were carried out with an iodIde ISE. Results of the analyses are shown in Table 26. The standard deviation for the results by potentiometric titration was $0.56 \%$. Kalman et $a \tau{ }^{16}$ have determined some alkaloid halides by potentlometrlc titration with $0.01 \mathrm{M}$ silver nitrate in an aqueous medium acidifled with nitric acld. The hydrochlorides of ethylmorpholine, quintne, 
Table 26. Determination of the hallde content of various pharmaceutical compounds.

\begin{tabular}{|c|c|c|c|c|c|}
\hline Compound & $\begin{array}{l}\text { Solution used } \\
\text { for calibration }\end{array}$ & $\begin{array}{l}\text { Concent } \\
\text { Direct } \\
\text { method }\end{array}$ & $\begin{array}{r}\text { Ion in pX } \\
\begin{array}{r}\text { Titration } \\
\text { method }\end{array}\end{array}$ & $\Delta \mathrm{pX}$ & $\begin{array}{l}\text { Method for } \\
\text { preparing } \\
\text { solution }\end{array}$ \\
\hline $\begin{array}{l}\text { Group A- } \\
\text { 1. Acriflavine } \\
\text { hydrochloride }\end{array}$ & $\mathrm{KCl}$ & $\begin{array}{l}2.84 \\
3.84\end{array}$ & $\begin{array}{l}2.80 \\
3.80\end{array}$ & $\begin{array}{l}0.04 \mathrm{pC1} \\
0.04 \mathrm{pC1}\end{array}$ & $\begin{array}{l}\mathbf{A} \\
\mathbf{A}\end{array}$ \\
\hline 2. Crystal violet & $\begin{array}{l}\mathrm{KC1} \\
\mathrm{KC1}\end{array}$ & $\begin{array}{l}2.92 \\
3.88\end{array}$ & $\begin{array}{l}2.88 \\
3.89\end{array}$ & $\begin{array}{l}0.04 \mathrm{pCl} \\
0.01 \mathrm{pCl}\end{array}$ & $\begin{array}{l}\mathbf{A} \\
\mathbf{A}\end{array}$ \\
\hline 3. Fuchsine base & $\mathrm{KCl}$ & 2.06 & 2.02 & $0.04 \mathrm{pCl}$ & $\Lambda$ \\
\hline 4. Malachite green & $\begin{array}{l}\mathrm{KCl}-\mathrm{KNO}_{3} \\
\mathrm{KCl}-\mathrm{KNO}_{3}\end{array}$ & $\begin{array}{l}2.79 \\
3.77\end{array}$ & $\begin{array}{l}2.74 \\
3.74\end{array}$ & $\begin{array}{l}0.05 \mathrm{pCl} \\
0.03 \mathrm{pC1}\end{array}$ & $\begin{array}{l}\mathbf{A} \\
\mathbf{A}\end{array}$ \\
\hline 5. Methylene blue & $\begin{array}{l}\mathrm{KCl}-\mathrm{KNO}_{3} \\
\mathrm{KCl}-\mathrm{KNO}_{3} \\
\mathrm{KCl}-\mathrm{KNO}_{3}\end{array}$ & $\begin{array}{l}2.08 \\
3.08\end{array}$ & $\begin{array}{l}2.04 \\
3.04\end{array}$ & $\begin{array}{l}0.04 \mathrm{pCl} \\
0.04 \mathrm{pCl} \\
0.02 \mathrm{pCl}\end{array}$ & $\begin{array}{l}\mathbf{A} \\
\mathbf{A} \\
\mathbf{A}\end{array}$ \\
\hline 6. Rose benga1 & $\begin{array}{r}\mathrm{KC1}-\mathrm{KNO}_{3} \\
\mathrm{KI}-\mathrm{KNO}_{3}\end{array}$ & $\begin{array}{l}3.05 \\
3.03\end{array}$ & $\begin{array}{l}3.07 \\
3.03\end{array}$ & $\begin{array}{l}0.02 \mathrm{pC} 1 \\
0.00 \mathrm{pI}\end{array}$ & B \\
\hline $\begin{array}{l}\text { Group B - } \\
\text { 1. ChlorambuclI }\end{array}$ & $\mathrm{KCl}-\mathrm{KNO}_{3}$ & 3.00 & 3.00 & $0.00 \mathrm{pCl}$ & B \\
\hline 2. Cyclophosphamide & $\mathrm{KCl}-\mathrm{KNO}_{3}$ & 3.00 & 3.00 & $0.00 \mathrm{pC1}$ & $\mathrm{B}$ \\
\hline 3. Degranol & $\begin{array}{l}\mathrm{KCl}-\mathrm{KNO}_{3} \\
\mathrm{KCl}-\mathrm{KNO}_{3} \\
\mathrm{KCl}-\mathrm{KNO}_{3} \\
\mathrm{KCl}-\mathrm{KNO}_{3}\end{array}$ & $\begin{array}{l}1.64 \\
2.62 \\
3.60 \\
2.56\end{array}$ & $\begin{array}{l}7.63 \\
2.63 \\
3.63 \\
2.60\end{array}$ & $\begin{array}{l}0.01 \mathrm{pCl} \\
0.01 \mathrm{pCl} \\
0.03 \mathrm{pCl} \\
0.04 \mathrm{pCl}\end{array}$ & $\begin{array}{l}\text { A } \\
\text { A } \\
\text { A } \\
\text { B }\end{array}$ \\
\hline 4. Mustine & $\begin{array}{l}\mathrm{KCl}-\mathrm{KNO}_{3} \\
\mathrm{KCl}-\mathrm{KNO}_{3} \\
\mathrm{KCl}-\mathrm{KNO}_{3} \\
\mathrm{KCl}-\mathrm{KNO}_{3}\end{array}$ & $\begin{array}{l}2.00 \\
3.00 \\
4.00 \\
2.86\end{array}$ & $\begin{array}{l}3.00 \\
4.00 \\
2.86\end{array}$ & $\begin{array}{l}0.00 \mathrm{pCl} \\
0.00 \mathrm{pCl} \\
0.00 \mathrm{pCl} \\
0.00 \mathrm{pCl}\end{array}$ & $\begin{array}{l}\text { A } \\
\text { A } \\
\text { A } \\
\text { B }\end{array}$ \\
\hline 5. Myelobromol & $\mathrm{KBr}-\mathrm{KNO}_{3}$ & 3.00 & 3.01 & $0.01 \mathrm{pBr}$ & B \\
\hline $\begin{array}{l}\text { Group C - } \\
\text { 1. Chloramphenicol }\end{array}$ & $\mathrm{KC1}-\mathrm{KNO}_{3}$ & 3.01 & 3.02 & $0.01 \mathrm{pCl}$ & B \\
\hline $\begin{array}{l}\text { 2. Chlortetracycline } \\
\text { hydrochloride }\end{array}$ & $\begin{array}{l}\mathrm{KCl}-\mathrm{KNO}_{3} \\
\mathrm{KCl}-\mathrm{KNO}_{3} \\
\mathrm{KCl}-\mathrm{KNO}_{3} \\
\mathrm{KCl}-\mathrm{KNO}_{3}\end{array}$ & $\begin{array}{l}2.01 \\
3.01 \\
4.00 \\
3.02\end{array}$ & $\begin{array}{l}2.01 \\
3.01 \\
4.01 \\
3.00\end{array}$ & $\begin{array}{l}0.00 \mathrm{pCl} \\
0.00 \mathrm{pCl} \\
0.01 \mathrm{pCl} \\
0.02 \mathrm{pCl}\end{array}$ & $\begin{array}{l}\text { A } \\
\text { A } \\
\text { A } \\
\text { B }\end{array}$ \\
\hline $\begin{array}{l}\text { 3. Griseofulvin } \\
\text { 4. oxytetracycline } \\
\text { hydrochloride }\end{array}$ & $\begin{array}{l}\mathrm{KCl}-\mathrm{KHO}_{3} \\
\mathrm{KCl}-\mathrm{KHO}_{3} \\
\mathrm{KCl}-\mathrm{KHO}_{3} \\
\mathrm{KCl}-\mathrm{KHO}_{3}\end{array}$ & $\begin{array}{l}2.99 \\
2.04 \\
3.04 \\
4.04\end{array}$ & $\begin{array}{l}3.01 \\
2.02 \\
3.02 \\
4.02\end{array}$ & $\begin{array}{l}0.02 \mathrm{pC1} \\
0.02 \mathrm{pCl} \\
0.02 \mathrm{pCl} \\
0.02 \mathrm{pCl}\end{array}$ & $\begin{array}{l}\text { B } \\
\text { A } \\
\text { A } \\
\text { A }\end{array}$ \\
\hline
\end{tabular}


Table 26. (Continued)

\begin{tabular}{|c|c|c|c|c|c|}
\hline Compound & $\begin{array}{l}\text { Solution used } \\
\text { for calibration }\end{array}$ & $\begin{array}{l}\text { Concent } \\
\text { Direct } \\
\text { method }\end{array}$ & $\begin{array}{r}\text { Ion in pX } \\
\text { Titration } \\
\text { method }\end{array}$ & $\Delta \mathrm{pX}$ & $\begin{array}{l}\text { Method for } \\
\text { preparing } \\
\text { solution }\end{array}$ \\
\hline 5. Tetracycline & $\mathrm{KC1}-\mathrm{KNO}_{3}$ & 2.02 & 2.00 & $0.02 \mathrm{pC1}$ & $\mathrm{A}$ \\
\hline hydrochloride & $\mathrm{KC1}-\mathrm{KNO}_{3}$ & 3.02 & 3.00 & $0.02 \mathrm{pCl}$ & $\mathbf{A}$ \\
\hline & $\mathrm{KCl}-\mathrm{KNO}_{3}$ & 4.02 & 4.00 & $0.02 \mathrm{pCl}$ & $\Lambda$ \\
\hline
\end{tabular}

Group D -

1. Chloropyraminum

$\begin{array}{ll}\mathrm{KC1}-\mathrm{KNO}_{3} & 2.97 \\ \mathrm{KC1}-\mathrm{KNO}_{3} & 2.97 \\ \mathrm{KC1}-\mathrm{KNO}_{3} & 3.97 \\ \mathrm{KC1}-\mathrm{KNO}_{3} & 2.76\end{array}$

$2.00 \quad 0.03 \mathrm{pCl}$

A

hydrochloride

2.97

3.00

$0.03 \mathrm{pCI}$

A

4.00

$0.03 \mathrm{FCl}$

A

2.74

$0.02 \mathrm{pCl}$

B

2. Chlorpromazine

hydrochloride

$\begin{array}{ll}\mathrm{KC1} & 2.02 \\ \mathrm{KC1} & 3.00 \\ \mathrm{KCl} & 4.02 \\ \mathrm{KC1}-\mathrm{KMO}_{3} & 2.79\end{array}$

02

$2.00 \quad 0.02 \mathrm{pCl}$

A

.00

3.00

$0.00 \mathrm{pC1}$

A

4.00

$0.02 \mathrm{pC1}$

A

2.80

$0.01 \mathrm{pc1}$

B

3. Mepacrine

KC1

2.02

2.00

$0.02 \mathrm{pC1}$

A

hydrochloride

KCI

3.71

3.70

$0.01 \mathrm{pCL}$

A

$\mathrm{KCl}-\mathrm{KNO}_{3}$

2.74

2.74

$0.00 \mathrm{pCl}$

B

Group E -

Liothyronine

hydrochloride

$\begin{array}{rl}\mathrm{KCI}-\mathrm{KNO}_{3} & 3.44 \\ \mathrm{KI}-\mathrm{KNO}_{3} & 3.00\end{array}$

$3.40 \quad 0.04 \mathrm{pCl}$

B

$3.01 \quad 0.01 \mathrm{pI}$

B

Group F -

Dicophane

$\mathrm{KCl}-\mathrm{KNO}_{3}$

2.70

$2.70 \quad 0.00 \mathrm{pCl}$

B

Group G -

Iodochlorbydroxy-

$$
\begin{array}{r}
\mathrm{KC1}-\mathrm{KNO}_{3} \\
\mathrm{KI}-\mathrm{KNO}_{3}
\end{array}
$$

2.94

2.96

0.02 pC1

B

quinoline

2.94

$2.940 .00 \mathrm{pI}$

$B$

Group H -

1. Pethidine

hydrochloride

$\mathrm{KC1}-\mathrm{KNO}_{3}$

2.02

2.01

$0.01 \mathrm{pCl}$

A

$$
\mathrm{kC1}-\mathrm{KNO}_{3}
$$

3.02

3.01

$0.01 \mathrm{pC1}$

A

$\mathrm{KCl}-\mathrm{KaO}_{3}$

4.02

4.01

0.01 pC1

A

2. Thiamine

$\mathrm{KC1}-\mathrm{KNO}_{3}$

1.72

1.69

0.03 pCl

A

hydrochloride

$\mathrm{KC1}-\mathrm{KMO}_{3}$
$\mathrm{KC1}-\mathrm{KarO}_{3}$

2.72

2.69

0.03 pC1

A

$\mathrm{kC1}-\mathrm{KNO}_{3}$

3.72

3.69

0.03 pC1

A

${ }^{a}$ Solutions were prepared by dissolving the compound in distilled water (A) or after Schöniger combustion (B). 
codeine, ephedrine, and tetracaine were determined using a chloride ISE. The hydrobromides of homatropine and scopolamine along with methylhomatropine bromide were determined using a bromide ISE. For binary mixtures, the ISE corresponding to the less soluble halide was used. The pharmaceuticals were determined neat and in varlous pharmaceutical preparations. The accuracy was within $2.5 \%$. Such substances as amidazophene and phenobarbital (frequently present in pharmaceuticals) did not interfere.

The direct electrometric measurement technique has also been used by severa1 other workers. Gyenge et al. ${ }^{17,18}$ have determined the bromine content of some organic compounds after releasing the covalent bromine with sodium in isobutanol. The solutions were adjusted to $\mathrm{pH} 10$ to 11 prior to emf measurements, which were performed with a bromide ISE (Radelkis OP-Br-7112-C) and an SCE.
The compounds analyzed were n-buty 1 bromlde, bromocamphor, 4-bromoacetophenone, 5-bromosalicylic acid, and 4-methoxy-3,5-dtbromobenzoy1 chloride. Some results are shown in Table 27, which gives the mean values of 3 to 5 determinations. "ine relative error was $1 \%$. Concentrations were obtained from callbration curves covering the range of 1 to $10^{-4} M$. The method was found to be faster and more sensitive than the VoIhard method.

Vajda and Kovacs ${ }^{19}$ reported the determination of the following chlorine-containing pesticides: Kaptan (N-trIchloromethy1mercap totetrahydrophthalimide), Folpet (N-trichloromethylymercap tophtha1imide), Difolatan $(N-1,1,2,2$-tetrachloroe thy 1su1finy1-cis-4-cyclohexene-I,2-dicarboximide), and Dipterex (0.0-dimethy12,2,2-trich Loro-1-hydroxyethylphosphonate). The samples were burned in an oxygen-flask; the products were absorbed in dilute sodium hydroxide.

Tab1e 27. Determination of the bromine content of pharmaceutical preparations.

\begin{tabular}{lccc}
\hline & \multicolumn{3}{c}{ Bromine content } \\
\cline { 2 - 4 } Compound & $\begin{array}{c}\text { Theory } \\
\%\end{array}$ & $\begin{array}{c}\text { Volhard } \\
\%\end{array}$ & $\begin{array}{c}\text { Ion-selective } \\
\%\end{array}$ \\
\hline n-Buty1 bromfde & 58.4 & 57.6 & 56.4 \\
Bromocamphor & 34.6 & 34.6 & 34.5 \\
4-Bromacetophenone & 40.2 & 39.8 & 39.4 \\
5-Bromosalicyc1lc acid & 36.8 & 36.0 & 35.8 \\
4-Methoxy-3,5-dibromobenzoy1 chloride & 47.8 & - & 47.0 \\
\hline
\end{tabular}


After neutralization with diluted sulfuric acid the solutions were diluted to $100 \mathrm{ml}$. Aliquots were taken for direct emf measurement with a Radelkis OP-C1-711 chloride ISE in a background of $0.1 M$ potassium nitrate. A calibration curve was prepared with potassium chloride solutions. The aliquot size was adjusted so that the chloride concentration was between $10^{-2}$ and $10^{-3} \mathrm{M}$.

A review of the use of halogen ISE's in the analysis of pharmaceuticals, pesticides, and biological products was published in Hungarian. 20

A summary of the more important methods for the determination of halogens in organic compounds using ISE's is presented in Table 28. The non-ionic halogen is converted to halide by combustion in oxygen. This may be accomplished by combustion in an oxygen-f1ask, an oxygen-bomb, or a tube over a catalyst. Reduction with aluminum in a basic solution has been used for some iodine-containing compounds, while the covalently-bound bromine has been released in some compounds by means of sodfum at $\mathrm{pH}$ 10. Methods of determination are mostly by potentiometric titration with silver or mercuric ions. A silver sulfide ISE is usually used to monitor the emf's.

Table 28. Summary of methods for halogen in organic compounds using ISE's.

\begin{tabular}{|c|c|c|c|c|c|c|}
\hline Ref. & $\begin{array}{l}\text { Method of } \\
\text { decomposition }\end{array}$ & $\begin{array}{l}\text { Halogen } \\
\text { de :d. }\end{array}$ & $\begin{array}{l}\text { Absorbing } \\
\text { medium }\end{array}$ & $\begin{array}{l}\text { Indfcator } \\
\text { electrode }\end{array}$ & $\begin{array}{l}\text { Titrant or } \\
\text { method }\end{array}$ & $\begin{array}{l}\text { Titration } \\
\text { medfum }\end{array}$ \\
\hline 2 & $\begin{array}{l}\text { Combustion In } \\
\text { tube over Pd, } \\
\mathrm{Pt}, \mathrm{SIO}_{2}\end{array}$ & $\begin{array}{l}\text { Al1 } \\
\text { halides }\end{array}$ & $\begin{array}{l}80 \% \text { Acetic acid } \\
1 \% \mathrm{H}_{2} \mathrm{O}_{2} \\
1 \% \mathrm{~N}_{2} \mathrm{l}_{4}^{2}\end{array}$ & $\mathrm{Ag}_{2} \mathrm{~S}$ & $0.003 \mathrm{M} \mathrm{\textrm {AgNO } _ { 3 }}$ & $\begin{array}{l}\text { Same as } \\
\text { absorbing } \\
\text { medium }\end{array}$ \\
\hline 3 & $\begin{array}{l}\text { Combustion in } \\
\text { tube over } \mathrm{Pd} \text {, } \\
\mathrm{Pt}, \mathrm{S}_{2} \mathrm{O}_{2}\end{array}$ & $\begin{array}{l}\text { Chloride, } \\
\text { others } \\
\text { also } \\
\text { possible }\end{array}$ & $\begin{array}{l}75 \% \text { Acetic acid } \\
1 \% \mathrm{H}_{2} \mathrm{O}_{2}\end{array}$ & $\mathrm{Ag}_{2} \mathrm{~S}$ & $0.0 \mathrm{M} \mathrm{AgNO}_{3}$ & $\begin{array}{l}\text { Same as } \\
\text { absorbing } \\
\text { medium }\end{array}$ \\
\hline 6 & $\begin{array}{l}\text { Combustion } \mathrm{In} \\
\text { tube over } \mathrm{Pt} \text {, } \\
\mathrm{SHO}_{2}\end{array}$ & $\begin{array}{l}\text { Chloride, } \\
\text { bromide }\end{array}$ & $\begin{array}{l}80 \% \text { Acetic acld } \\
1.2 \% \mathrm{H}_{2} \mathrm{O}_{2} \\
1.5 \% \mathrm{HNO}_{3} \\
0.14 \% \mathrm{HgCl}_{2}\end{array}$ & $\mathrm{Ag}_{2} \mathrm{~S}$ & $0.05 \mathrm{Hg}(\mathrm{I}, \mathrm{I})$ & $\begin{array}{l}\text { Same as } \\
\text { absorbing } \\
\text { nedium }\end{array}$ \\
\hline 7 & oxygen bomb & $\begin{array}{l}\text { Chlorlde, } \\
\text { athers } \\
\text { also } \\
\text { possible }\end{array}$ & $\begin{array}{l}0.1 \mathrm{HaOH} \text { or } \\
\text { water }\end{array}$ & Chlortde & $\begin{array}{l}0.05 \mathrm{M} \mathrm{AgNO}_{3} \\
\text { or } 0.025 \mathrm{M} \\
\mathrm{Hg}\left(\mathrm{ClO}_{4}\right)_{2}\end{array}$ & $\begin{array}{l}\text { Water or } \\
\text { water/methanol } \\
\text { mixture }\end{array}$ \\
\hline 11 & $\begin{array}{l}\text { Reduction } \\
\text { with AI at } \\
\text { pH } 11\end{array}$ & Iodide & & IodIde & $\begin{array}{l}\text { Direct emf } \\
\text { measurement }\end{array}$ & $\begin{array}{l}\text { Aqueous, } \\
\mathrm{pH} 7\end{array}$ \\
\hline 17,18 & $\begin{array}{l}\text { Reduction with } \\
\text { Na at pH } 10\end{array}$ & Bromide & Isobutanol & Bromide & $\begin{array}{l}\text { Direct emf } \\
\text { measurement }\end{array}$ & \\
\hline 14,15 & Oxygen-flask & $\begin{array}{l}\text { Chloride } \\
\text { bromide } \\
\text { lodtde }\end{array}$ & Water & Halıde & $\begin{array}{l}\text { Direct and } \\
\text { potentio- } \\
\text { metric } \\
\text { titration }\end{array}$ & Aqueous \\
\hline
\end{tabular}




\section{References}

1. E. C. O1sen, "Organic Analysis: Chlorine, Brontne, and Iodine," in Treatise on Analytical Chemistm, Part II, Vol. 14, I. M. Kolthoff and P. J. Elving, Eds. (Interscience, New York, 1971) p. 1.

2. W. Krijgsman, B. Griepink, J. F. Mansveld, and W. J. van Oort, Mikrochim. Acta, 1970, 793.

3. W. Krijgsman and B. Griepink, 6th International Symposium on Microtechniques, Graz, Austria, Sept. 7-11, 1970, p. 129.

4. J. Slanina, J. Agterdenbos, and B. Griepink, Mikrochim. Acta, 1970, 1225.

5. W. Krijgsman, J. F. Mansveld, and B. Griepink, Z. AnaZ. Chem., 249, 368 (1970).

6. W. Potman and E. A. M. F. Dahmen, Mikrochim. Acta, 1972, 303.

7. G. L. Crossman and W. Selig, Lawrence Livermore Laboratory, Livermore, Calif., Rept. UCID-15444 (1969); cf. Chem. Abstr. 71, 5025n (1969).

8. W. Selig and G. L. Crossman, Lawrence Livermore Laboratory, Livermore, Calif,, Rept. UCID-15623 (1970).

9. C. Harzdorf, Z. anal. Chem., 215, 246 (1966).

10. S. S. M. Hassan, 2. anal. Chem., 266, 272 (1973).

11. B. Paletta and K. Panzenbeck, Clin. Chim. Acta, 26, 11 (1969).

12. E. Papp and E. Pungor, 2. anaZ. Chem., 250, 31 (1970).

13. E. Papp and E. Pungor, Magy. Kem. Foly., 76, 573 (1970); through Chem. Abstr., 74, 57358e (1971).

14. E. Pungor, K. Toth, and M. K. Papay, Chem. Analit. (Warsaw), 17, 947 (1972) ; cf. Chem. Abstr., 78, 92293j (1973).

15. Y. M. Dessouky, K. Toth, and E. Pungor, Analyst, 95, 1027 (1970).

16. J. Kalman, K. Toth, and D. Kuttel, Acta Pharm. Hung., 41, 267 (1971); through Chem. Abotr., 76, 50003t (1972).

17. R. Gyenge, J. Liptak, and J. Szava, Lucr, Conf. Nat. Chim. Ana1., 3rd, 1, 639 (1971); through Chem Abstr., 76, 148573d (1972).

18. R. Gyenge and J. Liptak, Proc. Conf. Appl. Phys. Chem., 2nd, 1, 639 (1971); through Chem. Abstr., 76, 67951y (1972).

19. L. Vajda and J. Kovacs, thung. Sei. Instruments, 20, 31 (1971).

20. D. Kuettel, Kem. Kozlem., 38, 235 (1972); through Chem. Abstr., 78, 88628 e (1973). 


\section{Phosphores and Arsenic}

A thorough treatment of the analysis of phosphorus in organic compounds is given in the monograph by Laws, ${ }^{1}$ and for arsentc in that by Gorsuch. ${ }^{2}$ No papers have appeared so far on these analyses using ISE's. Our remarks are therefore based on the findings with inorganic matrices and must be experimentally vertfled for organic compounds.

We favor combustion of organic compounds in an oxygen-flask because of the simplicity of this method and the low level of extraneous lons introduced. However, some difficulties exist in the combustion of organic compounds containing phosphorus and, especially, arsenic. Suffice It to mention here that on combustion of arsenic-contalning compounds, platinum-arsentc alloys may be formed, leading to low results. ${ }^{3}$ Some workers, therefore, recommend substituting the platinum holder of the oxygenflask by a quartz spiral ${ }^{4}$ or wrapping the sample carrier in quartz wool, 3 while others prefer a wet-combustion method. 5,6

In the combustion of phosphoruscontaining organte compounds, the phosphorus molety is converted to orthophosphate. The orthophosphate may then be determined by potent $1-$ ometric titration, with an Ion forming an insoluble phosphate, or by an indirect Gran's plot titration (see Ref. 14).

Phosphate forms a very insoluble lead salt. Selig has determined it by potentiometric titration with lead perchlorate in an aqueous solution buffered at $\mathrm{pH} 8.25$ to 8.75 . $\mathrm{Emf}^{\prime} \mathrm{s}$ were monitored with a lead ISE and a double-junction reference electrode. In the titration of micro amounts of phosphate, a 320-fold excess of sulfate and a 100-fold excess of nitrate did not interfere. In the presence of up to a 100-fold excess of chloride and a 133-fold excess of fluoride, slightly high recoveries of phosphate were obtained: the average recovery in the presence of chloride was $101.7 \%$ and, in the presence of fluoride, 100.5\%." Silicate interfered if present in amounts larger than the phosphate. $\operatorname{SelIg}^{8}$ has also conmented on the determination of phosphate and fluoride without separation. Orthophosphate can also be determined by titration with silver Ions: Flatt and Brunisholz ${ }^{9}$ have determined it by direct potentlometric titration In an aqueous solution buffered at pH 9 with borax or by prectpitation of the phosphate with excess silver Ions at pH ? to 8 . The latter method required filtration of the precipltate prior to the potentiometric titration of the excess silver Lons with standard potassium bromide solution. 
Levy ${ }^{10}$ did not find the direct titration suggested by Flatt and Bruntsholz 9 posstble on the microscale. He determined microamounts of phosphorus in organic compounds after wet-oxidation with concentrated sulfuric acid. The solution was then neutralized and buffered with borax; the orthophosphate was precipitated with an excess of silver ions. After filtration, this excess was determined by potentiometric titration with standard potassium chloride solution. The determination was made in an aqueous medium.

Christian et al. ${ }^{11}$ determined phosphate in a medium $80 \%$ in ethanol and $0.1 M$ in sodium acetate by direct potentiometric titration whth silver nitrate. Halides interfered by coprecipitation, but equimolar amounts of sulfate could be tolerated.

Several potentiometric precipitation titrations of orthophosphate with silver ions have been re-examined by Selig. 12 The titrations were monitored with a silver sulfide ISE and a double-junction reference elec- trode. Because of the relatively high solubility of silver phosphate, a partially nonaqueous medium was mandatory. This study also examined the amounts of fluoride and sulfate that can be tolerated. The results are summarized in Table 29.

The recently reported barium ISE ${ }^{13}$ may make it possible to determine orthophosphate by direct titration with barlum tons in an aqueous medium. The solubility products for the varlous phosphates resulting upon titration with the titrants suggested above are given in Table 30 .

The fluoride ISE has been recom mended for monitoring the indirect determination of orthophosphate. ${ }^{14}$ Phosphate was precipttated with an excess of lanthanum nitrate; the excess of lanthanum was then titrated with standard fluoride solution, the emf being monitored with the fluoride ISE. Equivalence points were located on volume-corrected Gran plot paper. The lanthanum nitrate solution was buffered to $\mathrm{pH} 4.8$ with a sodium acetate/acetic acid buffer. The

Table 29. Comparison of buffer systems for the titration of phosphate with silver nitrate.

\begin{tabular}{lcccc}
\hline Buffer & Solvent & TItrant & Max F/P & Max S/P \\
\hline Borate/borlc acid & $60 \%$ methanol & $0.05 \mathrm{M} \mathrm{AgNO}_{3}$ & 420 & $>300$ \\
Borate/bortc acid & $70 \%$ methanol & $0.005 \mathrm{M} \mathrm{AgNO}_{3}$ & 1840 & $>>300$ \\
$0.1 \mathrm{M}$ sodium acetate & $80 \%$ methano1 & $0.05 \mathrm{M} \mathrm{AgNO}_{3}$ & 80 & $<5$ \\
$0.1 \mathrm{M}$ sodium acetate & $80 \%$ methanol & $0.005 \mathrm{M} \mathrm{AgNO}_{3}$ & Titration not feasible \\
\hline
\end{tabular}


Table 30. Solubility products of some orthophosphates.

\begin{tabular}{lc}
\hline Cation & $-\log \mathrm{K}_{\mathrm{sp}}, 25^{\circ} \mathrm{C}$ \\
\hline $\mathrm{Ag}^{+}$ & 15.8 \\
$\mathrm{Ba}^{++}$ & 38.2 \\
$\mathrm{~Pb}^{++}$ & 42.1 \\
\hline
\end{tabular}

interference of sulfate can be eliminated by its precipitation with barIum ions. As In similar methods using Gran plot paper, the prectsion and accuracy of this method is no better than $\pm 5 \%$ vs the $1 \%$ easily obtainable in potentiometric titrations.

Arsenate is quite simflar to phosphate in some of its chemical properties, hence the same reagents can be used for its determination. Selig ${ }^{15}$ has determined it in an inorganic matrix using varlous methods employing ISE's. It may be determined by potentiomeiric titration with lead perchlorate in an aqueous medium using a lead ISE. The optimum $\mathrm{pH}$ for this determination is between 8.4 and 8.9. Interferences have not been investigated, but they are most probably quite similar to those for the determination of phosphate.

Arsenate, like phosphate, can also be determined with silver fons: Lévy ${ }^{16}$ determined it in organtc compounds in an analogous fashion to his phosphate method. 10 Compounds were mineralized with concentrated sul- furtc actd. The solutions were then neutralized and buffered with borax; the arsenate was precipltated with excess silver nitrate. After filtration, the excess stlver fon was determined by potentiometric titration with standard potassium chloride in an aqueous medfum.

Stefanac ${ }^{17}$ has precipttated arsenite or arsenate or both with silver nitrate in a solution buffered with $2 \%$ sodfum acetate. For this determination, it is immaterial whether the arsenic is present in the +3 or +5 oxidation state. We have found 15 that the direct potentiometric determination of arsenate with silver nitrate using a silver sulfide ISE is feastble only in partially nonaqueous medium. Some titration curves are shown In Fig. 8. Other indicator electrodes based on a silver sulfide matrix can probably also be used. The use of silver nitrate as titrant for arsenate requires the absence of halides and phosphate.

The barium ISE mentfoned previously ${ }^{13}$ may perhaps make the direct titration of arsenate with barium tons possible.

By analogy with phosphate, arsenate can also be precipitated with lanthanum nitrate. 15 The excess of lanthanum ton is then titrated with standard fluoride solution using a fluoride ISE to monftor potentials. Equivalence points are located on 


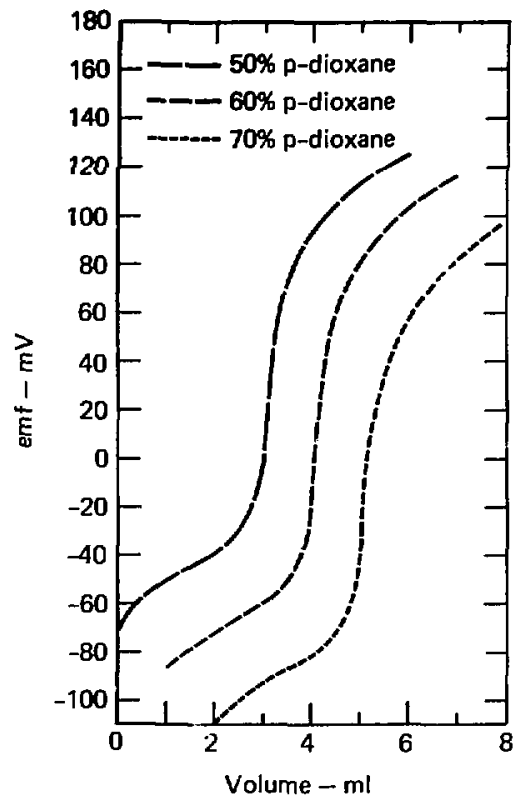

Fig. 8. Titration of $1.5 \mathrm{mg}$ As (V) with $0.02 \mathrm{M}$ silver nitrate in p-dioxane. (The curves have been displaced laterally for clarity.) Source: Ref. 15, used with permisston.

volume-corrected Gran plot paper. The lanthanum nitrate solution must be buffered at $\mathrm{pH} 8.65$. In the determination of $0.005 \mathrm{~m} U$ ar senate the average recovery was $103.6 \%$ in the presence of up to a 600-fold excess of chlorfde. Sulfate Interferes but can be eliminated by its precipitation with barium ions.

In summary, no methods using ISE have been published so far for the analysis of phosphorus and arsenic in organic compounds. Several suggestions based on results with inorganic matrices are offered here: phosphorus as orthophosphate and arsenic as arsenate may be determined by direct potentiometric titration with lead perchlorate in an aqueous medium using a lead ISE. In a partially nonaqueous medium, and in the absence of haiides, phosphorus and arsenic may be determined by direct titration with silver nitrate using a silver sulfide ISE. An indirect method is based on the precipitation of the lanthanum salts, and back-titration of the excess lanthanum with standard fluoride using a fluoride ISE. In each case, suitable buffering of the titration medium is required.

\section{References}

1. E. Q. Laws, "Organic Analysis: Phosphorus," in Treatise on Analytical Chemistry, Part II, Vol. I1, I. M. Kolthoff and P. J. Elving, Eds. (Intersclence, New York, 1965), p. 524.

2. T. T. Gorsuch, "Organic Aralysis: Determination of Other Elements," in Triatise on Analytical Chemistry, Part II, Vol. 12, I. M. Kolthoff and P. J. Elving, Eds. (Intersctence, New York, 1965), p. 330.

3. B. Griepink, H. Krijgsman, A. J. M. E. Leenaers-Smeet, J. Slanina, and H. Cufjpers, Mikrochim. Acta, 1969, 1018. 
4. W. Merz, Hikrochim. Acta, 1959, 456.

5. R. Belcher, A. M. G. MacDonald, and T. S. West, Talanta, 1, 408 (1958).

6. M. M. Tuckerman, J. D. Hodecker, B. C. Southworth, and K. D. Flefscher, Analyt. Chim. Acta, 21, 463 (1959).

7. W. Selig, Mikrochim. Acta, 1970, 564.

8. W. Selig, Mikrochim. Acta, 1974, 515.

9. R. Flatt and G. Brunisholz, Analyt. Chim. Acta, 1, 124 (1947).

10. R. Lévy, Compt. rend., 236, 1781 (1953).

11. G. D. Christian, E. C. Knoblock, and W. C. Purdy, Anal. Chem., 35, 1869 (1963).

12. W. Selig, Mikrochim. Acta, 1976 II, 9.

13. R. J. Levins, Mikrochim. Acta, 43, 1045 (1971).

14. Orion Research, Inc., Nessietter, $\underline{3}, 6$ (1971).

15. W. Selig, Mikrochim. Acta, 1973, 349.

16. R. Lévy, Compt. rend., 238, 2320 (1954).

17. Z. Stefanac, Mikrochim. Acta, 1962, 1115. 


\section{Boren * Tetraflechorate}

No papers have yet appeared on the determination of boron in organic compounds using an ISE. It has, however, been determined in agricultural samples using ISE's. Boron can be converted to tetrafluoborate, $\mathrm{BF}_{4}^{-}$, by reaction with hydrofluoric acid according to

$$
\mathrm{H}_{3} \mathrm{BO}_{3}+4 \mathrm{HF} \rightleftharpoons \mathrm{HBF}_{4}+3 \mathrm{H}_{2} \mathrm{O} .
$$

The fluoborate can then be determined by direct emf measurement or by potentiometric titration using a fluoborate ISE (Orion 92-05).

Prior to the commerical availability of such an ISE, Carlson and Paul ${ }^{1}$ converted the nitrate ISE (Orion 92-07) to the fluoborate form by treatment with boric and hydrofluoric acids. The boric acid in the sample was completely converted to fluoborate in $0.28 \mathrm{M}$ hydrofluoric acid at $60^{\circ} \mathrm{C}$ in 5 min. At lower temperatures and lower hydrofluoric acid concentrations, this conversion took considerably longer. The same authors recommended an alternate method for conversion of boron to fluoborate: a boron-specific ion exchange resin,
Amber1ite XE-243, concentrated boron and separated it from interfering Lons. After elution with sodium hydroxide, the fluoborate was then determined by direct emf measurement. The same authors ${ }^{2}$ subsequently used the fluoborate ISE (Orion 92-05) after converting the boron to fluoborate with Amber11te XE-243, as mentioned above. Boron in aqueous samples containing 0.1 to 2500 ppm can be determined by this method. Details of the column construction and regeneration are given. Interferences are also discussed.

Smith and Manahan ${ }^{3}$ determined boron by potentiometric titration of fluoborate with tetraphenylarsonium chloride. A fluoborate ISE was used as the endpoint detector. Titrations were performed at $2^{\circ} \mathrm{C}$ in order to decrease the solubility of the tetraphenylarsonium fluoborate and to increase the potential breaks at the endpoint. While at $25^{\circ} \mathrm{C}$, the lower linit of fluoborate that could be determined was near $20 \mathrm{~m} M$; at $2^{\circ} \mathrm{C}$, it was $5 \mathrm{mM}$.

Fe surmise that these methods will lend themselves easily to the analysis of boron in organic samples after mineralization.

\section{References:}

1. R. M. Carlson and J. L. Paul, AnaZ. Chem., 40, 1292 (1968).

2. R. H. Car1son and J. L. Pau1, Soil Soi., 108, 266 (1969).

3. M. J. Smith and S. E. Manahan, Analyt. Chim. Acta, 48, 315 (1969). 


\section{Orensic Anions}

Organic anions have been determined with three types of $\operatorname{ISE}^{\prime} s$ :

- Commerically available ISE's such as the calcium, lead and cupric ion electrodes.

A commerlcally avallable liquid ion-exchange electrode barrel in which the organic phase has been modified.

Special electrodes, such as the coated wire and plastic ISE's.

The anions determined include those of simple organic acids, amino acids, detergent anfons, and ligand anions. Detergent (or surfactant) anions will be treated in a separate section together with their respective cations.

Based on the survey of the 1iterature presented here, the user may be able to devise methods required for his own applications.

Mukherji $i^{1}$ has used a calcium ISE (Orion 92-20) as the endpoint detector in the determination of oxalate by titration with $0.1 \mathrm{M}$ calciur. chloride. Determinations were made in an aqueous medium, at $\mathrm{pH} 7$ to 11 . Amounts of oxalate range from 8.33 to $33 \mathrm{mg}$, the relative error varying from 2.3 to $0.6 \%$ as the amount of oxalate increased. A typical titration curve is shown in Fig. 9.

Selig ${ }^{2}$ has used a lead ISE as the endpoint detector in the potentiometric titration of semimicro

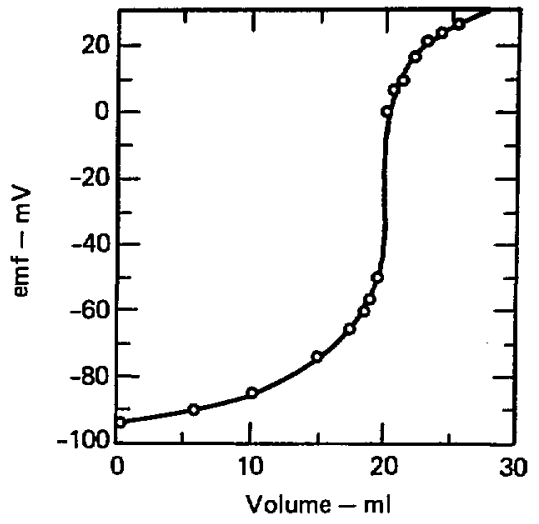

Fig. 9. Titration of $0.0993 \mathrm{M} \mathrm{K}_{2} \mathrm{C}_{2} \mathrm{O}_{4}$ with $0.0977 \mathrm{M} \mathrm{CaCl}_{2}$. Source: Ref. 1, used with permission.

amounts of oxalate. Although any $\mathrm{pH}$ between 3.5 and 9.5 was found practical, titrations were performed at $\mathrm{pH} 6$ to 7. The effect of $\mathrm{pH}$ is demonstrated in Fig. 10. Also, titrations can be performed in aqueous solution, but a $40 \%$ non-aqueous medium ( $\mathrm{p}$-dioxane) was recommended to enhance titration breaks. Over the range of 1 to $25 \mathrm{mg}$ of oxalic acid, titrations were stoichiometric. The average recovery was $100.06 \%$, with a standard deviation of $0.25 \%$. No interference was found from phthalate at 3 times the oxalate leve1, acetate at up to 18 times, formate at up to 24 times, and propionate at up to 19 times the oxalate leve1. Citrate and other complexing agents for lead interfere, as do anions forming insoluble lead salts. 


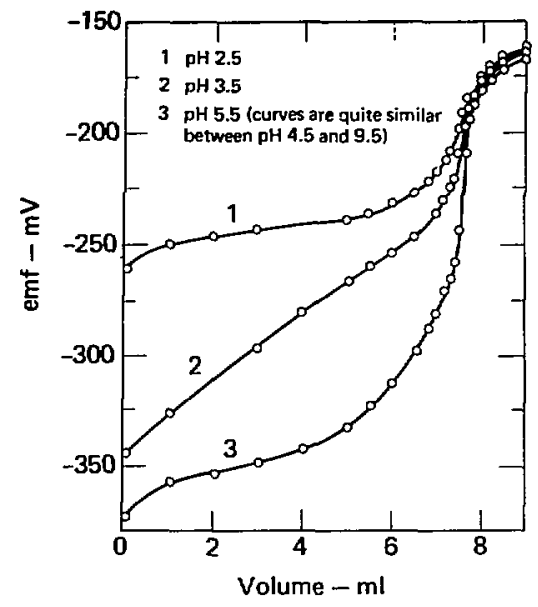

Fig. 10. Potentiometric titration of $10.12 \mathrm{mg}$ oxalic acid in $40 \%$ dioxane at various $\mathrm{pH}$ values; $0.01 \mathrm{M}$ lead perchlorate. Source: Ref. 2, used with permission.

Siska and Pungor ${ }^{3}$ have used halide ISE's for the potentiometric titration of tetraphyl borate with silver nitrate. The solutions were buffered at $\mathrm{pH} 5$; the titrant was 0.1 or $0.01 M$. The halide ISE's were conditioned prior to use by soaking in $10^{-3} \mathrm{M}$ sodium tetraphenylborate for $30 \mathrm{~min}$. The relative standard deviation was 0.38 to $0.49 \%$. If a partially nonaqueous medium is used, the emi change at the endpoint decreases with Increasing amount of the nonaqueous component, probably because of the Increasing solubility of the silver tetraphenylborate. A silver-wire electrode was used under the same conditions with similar results. No doubt the silver sulfide ISE wIll serve equally well.

Nitrilotriacetic acid (NTA) Is used as a substitute for phosphate in detergents. It has been determined by Rechnitz and Kenny ${ }^{4}$ by compleximetric titration with cupric ion using a copper ISE. As shown in Fig. 11, as 1ittle as $0.05 \mathrm{~m} / 4$ could be titrated. The titrant was $0.01 M$ cupric nitrate; titrations were performed in an aqueous medium buffered at $\mathrm{pH} 9.6$ with ammonium nitrate/ ammonia buffer. Titration of a fixed amount of NTA in the presence of varying amounts of phosphate, sulfate, and sulfonate decreased the

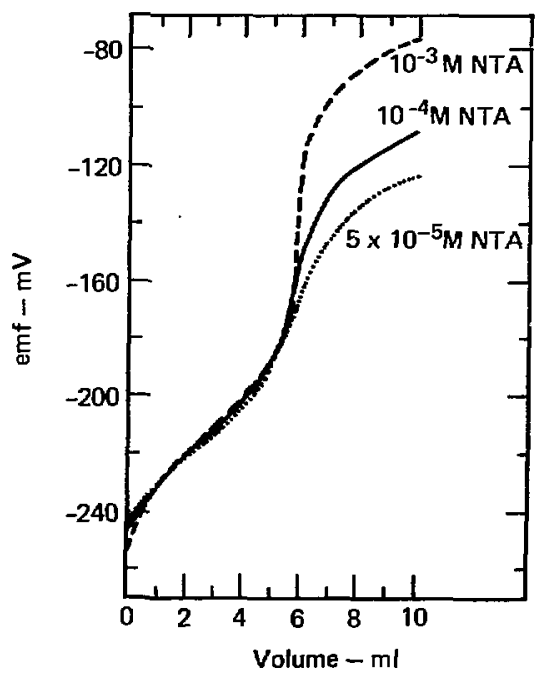

Fig. 11. Titration of NTA with copper (II) nitrate. Source: Ref. 4, used with permission. 
potential breaks near the endpoint, but did not affect the location of the endpoint. At least a fourfold excess of these usually interfering Ions could be tolerated.

Mascini and Liberti ${ }^{5}$ have decribed a heterogeneous membrane electrode for cadmium ion made by thermomoulding cadmium sulftde and polythene. This electrode has been used for the potentiometric titration of cadmium ion with NTA and EDTA in amoonia or acetate-buffered solutions. Conversely, NTA and EDTA can be determined by titration with cadmium Ion, using this cadmium ISE as endpoint detector. The electrode was also used in the precipitation titration of 8-hydroxyquinoline in the presence of ammonia buffer, in a medium consisting of $1: 1$ dioxane/ water. A titration curve is shown in Fig. 12. Again, by using the reverse titration, 8-hydroxyquinoline can be determined.

Rechnitz and Kenny ${ }^{5}$ have used the copper ISE for the compleximetric titration of cupric ion with several 1igands in methanol, acetone, and acetonitrile. Conversely, one can determine the ligands, ethylene diamine, tetraethylene pentamine, and 5,6-dinethy1-1,10-phenanthroline, by titration with cupric fon. The titrant was $0.01 \mathrm{M}$ cupric perchlorate; the 1Igands were $0.02 \mathrm{M}$. The authors state that in potentiometric t1tra-

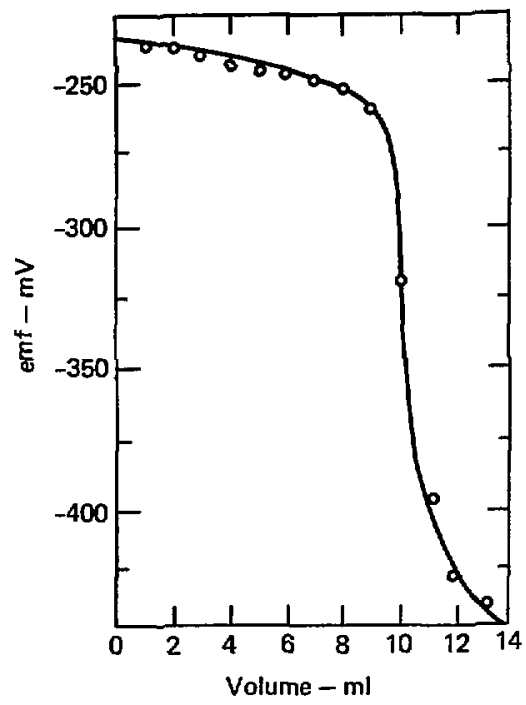

Fig. 12. Precipitation titration with 8 -hydroxyquinoline; 50 ml of $10^{-2} \mathrm{M}$ $\mathrm{Cd}^{2+}$ is titrated with $0.1 \mathrm{M}$ 8-hydroxyquinoline in ammonia buffer in $(1+1)$ water-1,4-dioxane medium. Source: Ref. 5, used with permission.

tions the response time at the beginning of the titration is rapid but the electrode required several minutes for stabilization near the endpoint when the cupric ion concentration is low.

The copper ISE has been used for chelometric titrations of a variety of metal cations with EDTA, tetraethylene pentamine, and 1,10-phenanthro1ine. Conversely, one can determine the IIgand antons by titration with a convenient metal cation such as copper (II). 7,8 
Many other anions that react with species that can be measured with ISE's can, no doubt, be determined very readily. An example is the determination of citrate by titration with cupric nitrate. ${ }^{9}$ This titration can be monitored with a copper ISE at $\mathrm{pH} 10$ to 12 .

Some organic anions have been determined by using commercially avallable electrode barrels, mainly the Orion calcium electrode (92-90). In each case, the organic phase of the commerclal electrode was replaced with one speclally prepared.

Coetzee and Freiser ${ }^{10}$ described anion-responsive electrodes based on ion-association extraction systems. The following organic salts (a variety of inorganic salts are also discussed) of methyl tricapryly1 ammonium ion (Allquat 336s) dissolved in 1-decanol functioned as the 1iquid phases: acetate, formate, propionate, oxalate, benzoate, p-toluenesulfonate, and salicylate. The aqueous reference phase consisted of $0.1 M$ sodium chloride and $0.1 M$ of the appropriate sodium or potassium salt of the organic anion. An Orion 92-20 membrane was used to separate organic and aqueous phases. The organic phase consisted of $10 z(v / v)$ of Aliquat 3365 in 1-decano1, which was converted to the proper form by shakIng repeatedly with an aqueous solu- tion of the sodium salt of the appropriate anion.

Electrodes were conditioned in $0.1 M$ solution of the approprlate ion for 2 to $3 \mathrm{~h}$. Near-Nernst Ian response was obtained over the range of $10^{-1}$ to $10^{-4} M$ for ail the anions with the exception of salicylate, which was Inear only to $10^{-3} M$. Constant emf readings were usually obtained within 1 min; readings were reproducible within $\pm 0,2 \mathrm{mV}$. The useful life span of the electrodes was one month or longer.

In further work Coetzee and Freiser ${ }^{11}$ studied the $\mathrm{pH}$ dependency and the effect of interfering anions on the response of their anion selective electrodes. In addition to the previously ${ }^{10}$ discussed electrodes, those for It- and p-toluate are described. Electrodes were prepared as described previously. Linear responses were obtained from $10^{-1}$ to $10^{-3} \mathrm{M}$, and in some cases to $10^{-4} \mathrm{M}$. Equilibrium potentials were reached within 20 to $60 \mathrm{~s}$. Changing the Aliquat concentration from 1 to $25 \%$ $(v / v)$ did not affect the electrode response. The useful lifespan of the electrodes was from one to two months. Although these electrodes cannot be considered as highly selective, a wide range of useful measurements can be made with them.

Haynes and Wagenknecht ${ }^{12}$ have described an ISE for measuring the 
unreacted salicylate lon concentration during the electroreduction of salicylic acid. As above, an Orion liquid membrane electrode barrel was used with a 92-19 porous membrane separating the organic phase from the test solution. The organic phase was prepared by dissolving tetraheptyl amonium todide in 1-decanol and exchanging the lodide for sallcylate by repeatedly shaking with an aqueous solution of $0.2 M$ sodium salicylate. The aqueous reference phase was $0.1 \mathrm{M}$ In sodium chloride and sodium salicy1ate. Electrodes were conditioned by soaking overnight in aqueous $0.2 M$ sodium salicylate.

Measurements of emf vs concentration yielded a Nernstian slope (58 mV) from $10^{-1}$ to $10^{-3} M$, of $51 \mathrm{mV}$ from $10^{1}$ to $1 M$, and of $48 \mathrm{mV}$ from $10^{-3}$ to $10^{-4} M$. The response time of the electrodes was almost Instantaneous; measurements were made after 3 min. Samples were adjusted to $\mathrm{pH} 8.5$ before analysis to minimize hydrogen ion interference. The known addition technique was used. Tons such as benzoate and p-hydroxybenzoate respond to the same extent as salicylate; thus, they interfere.

Back $^{13}$ studied a series of anionselective electrodes with respect to selectivity characteristics and examined the data in terms of theory of liquid-membrane electrodes. He also used an Orion calcium electrode bar- rel In which the organic 1Iquid phase and the water reference phase were placed using orion 92-20 membranes as separators. The organic phase consisted of $I M$ n-tetrahexyl ammonium picrate in methylene chloride. The aqueous phase was $0.1 \mathrm{M}$ sodium chloride and $I M$ sodium perchlorate. The electrodes were conditioned for several hours by immersion In a $1 M$ solution of the salt to be measured. Emf measurements were made under constant conditions: $50 \mathrm{ml}$ of solution was thermostated at $25 \pm 0.1^{\circ} \mathrm{C}$, electrodes were Inmersed to a constant depth, and stirring rates were constant.

The picrate ISE:was tested in pure solutions of the following interferIng lons: chloride, nitrate, bromide, iodide, and perchlorate. The activity range examined was from $10^{-4}$ to $1 M$. Equilibrium potentials were established within 20 to $60 \mathrm{~s}$ and values were reproducible to $\pm 0.2 \mathrm{mV}$. over the range of $10^{-4}$ to $10^{-1} M$, all response curves were Nernstian with a slope of $59 \mathrm{mV}$ per activity decade.

The response of the Orion nitrate (No. 92-07) and perchlorate (No. 9281) $\operatorname{ISE}^{\prime} s$ to a serles of substituted benzoates and phenylacetate tons was studied by Hirsch and olderman. 14 The relative response was determined by the nature and the extent of interaction between the solutes and the aqueous solvent; the response depends on the size of the substituent, 
as well as the position of substitution. The results are comparable to fon-exchange elution sequences and the relative order of liquid extractIon equilibrium constants. Since the electrodes are not very specific, a preliminary separation is required before a particular anion can be determined in a mixture. In fact, the response of these ISE's to a mixture of anions is additive. Detection 1imit. range from $5 \times 10^{-6} \mathrm{M}$ to $2 \times 10^{-2} M$.

Ishibashi and Jyo ${ }^{15}$ prepared a trifluoroacetate-selective electrode by using an organic solvent solution of the trifluoroacetate salt of crystal violet or of bis (bathophenanthroline)-iron(II) chelate. The response was linear from $10^{-3}$ to $3 \times 10^{-5} \mathrm{M}$, with a slope of $60 \mathrm{mV}$ per decade at $29^{\circ} \mathrm{C}$. Potentials were stable within $\pm 0.2 \mathrm{mV}$ over three days; the response time was several seconds. Divalent anions, chloride, fluoride, and acetate did not interfere. Iodide, perchlorate, and thiocyanate interfered seriously. Jyo et al. ${ }^{16,17}$ prepared ionselective electrodes responding to maleic and phthalic actds. Membranes were prepared from the organic solvent solution of the Ion-pair of the respective acid anion wth crystal violet or the tris(bathophenanthroline) Iron(II) Ion. The electrode response was linear from
$10^{-1}$ to $10^{4} \mathrm{M}$ for maleic actd at $\mathrm{pH} 3$ to 5 , and from $10^{-2}$ to $10^{-4.5} \mathrm{M}$ phthalic acid at $\mathrm{pH} 3.8$ to 4.2 . Equilibrium potentials were established within a few seconds and were reproducible within $\pm 0.2 \mathrm{mV}$.

The electrodes responded only to the monovalent antons of the acids. This is analytically advantageous because the slope of the calibration curve canirbe expected to be twice that of the divalent maleate or phthalate ions. Interference from acetate, benzoate, and chloride was extremely low; lodide and perchlorate, however, interfered seriously. Fumaric acid does not interfere with the maleic acid electrode. Isophthalic and terephthalic acids do not interfere with the phthalic acid electrode.

Shigematsu et al. ${ }^{18}$ prepared 1iquid membrane electrodes responding to organic anions used in antiseptics and artificial sweeteners. The organic phase consisted of a $10 \%$ solution of the methyltrioctylammonium salts of the corresponding anion in 1-decanol. Nerstian response was obtained over the range of $10^{-1}$ to $10^{-3} M$ for dehydroacetate, benzoate, p-hydroxybenzoate, salicylate, cyclohexylsulfamate, and o-benzosulfimide. The electrodes, however, were not very selective.

James et $a l^{19}$ examined the applicability of coated wire ISE's in 
which a platinum wire was coated with a polyvinyl chlorfde (PVC) solution of an ion-assoctation complex solution. The latter was prepared by repeatedly shaking a $60 \%(\mathrm{v} / \mathrm{v})$ solution of Aliquat 3365 in 1-decanol with an aqueous solution $(0.5-1 M)$ of the sodium salt of the appropriate anion in order to form the proper quaternary ammonium salt. For the phenylalanine and leucine electrodes a $30 \%(v / v)$ Alfquat $336 \mathrm{~S} /$ decanal solution was used.

Electrodes were prepared for the following organic antons: acetate, oxalate, benzoate, salicylate, phenylalanine, and leucine. Two methods for preparing the coated wire electrodes are presented. Electrodes were conditioned by soaking in a $10^{-1} M$ solution of the anion to be measured for $15 \mathrm{~min}$. Between use, electrodes were stored in air and reconditioned immediately before use by soaking again in a $10^{-1} M$ solution for 5 min. Electrodes still functioned after three months of use.

Equilibrium potentials were established usually within a few seconds and were reproductble to at least $\pm 0.5 \mathrm{mV}$. A near-Nernstian response was obtained from $10^{-1}$ to $10^{-4} \mathrm{M}$. The electrodes required dafly restandardization. The coated wire electrodes yielded greater selectivities than the corresponding Itquidnembrane electrodes in most instances.
The work has demonstrated the feasibility of constructing ISE's wthout an Internal reference solution.

In the preceding section, coated wire ISE's have been described for two amino acids, phenylalantne and leucine. Matsut and Fretser ${ }^{20}$ have prepared amtno-acid-responslve liquid membrane electrodes for tryptophane, phenylalanine, leucine, methionine, valine, and glutamic acid. The electrodes are based on the quaternary ammonium salts of the amino acids, and were prepared as described above. 11 However, a 10- $\mu \mathrm{m}$ millipore Teflon membrane was used to separate the organtc and aqueous phases. The organic phase consisted of a $10 \%$ $(v / v)$ decanol solution $(1 \%(v / v)$ for leucine and phenylalanine) of Aliquat $336 \mathrm{~S}$, which had been converted to the amino actd anion salt by repeated equilibration with a $0.1 M$ aqueous solution of the corresponding potassium or sodium salt. The internal reference solution consisted of a $0.1 M$ potassium chloride solution that was also $0.1 M$ in the potasstum salt of the appropriate amino acid at $\mathrm{pH}$ 10.5. Since the authors believed (from previous work) that the feasibility of electrode preparation for a particular ton pair is related to its extractabllity, the poorly extractable anfons such as those of relatively polar glycine and alanine were not considered. 
Equilibrium potentials mere reached within 2 to 3 min; values were reproductble to $\pm 0.5 \mathrm{mV}$. The concentration range for near-

Nernstian behavior was somewhat more restricted than was observed in earlier studies, 10,11 posstbly because of hydroxide interference at the high $\mathrm{pH}$ used. The response was 11near from $10^{-1}$ to near $10^{-3} \mathrm{M}$, the useful concentration range in general golng down to $10^{4} M$. The effect of interfering lons, mainly those of other amino acids and some commonly encounterea inorganic anions, was also studied.

Simple plastic membrane electrodes spectfic for relatively hydrophobic organic cations and anions were discussed by Higucht et al. ${ }^{21}$ According to the authors, any organic plastic matrix of 1imited hydrophilicity can be used as the gelling agent component of the membrane. The IIquid components were chosen for their ability to solvate the particular ion of interest. Utilization of a protondonating plasticizer may be expected to provide preferential solvation of negatively charged specles. Thus a phenolic-plasticlzed nylon electrode responds more to antons, such as tetrapheny1boron, than to cations. This is shown in FIg. 13.

A summary of the published methods for organtc antons is presented in Table 31. Most of the ISE's for organic anions are based on Ionassociation extraction systems and chelating extraction systems. These systems may be the forerunners of new types of ISE's taflored to a varlety of organic Ions.

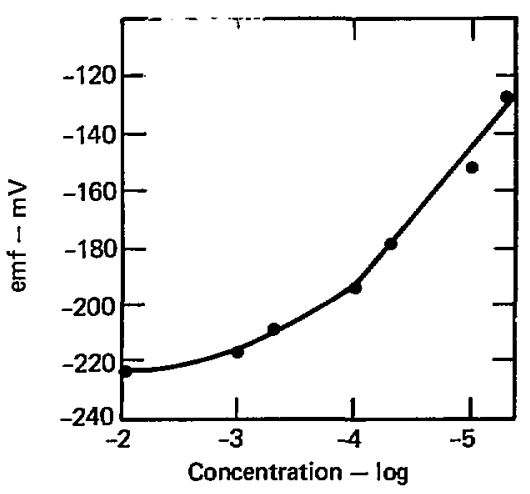

Fig. 13. Response of nylon-phenol membrane to sodfum tetraphenylboron slope for lowest concentration = 50.5). Source: Ref. 21, used with permission. 
Table 31. Summary of methods for organic antons using ISE's.

\begin{tabular}{|c|c|c|c|}
\hline Anton & Electrode & Method ${ }^{a}$ & Reference \\
\hline Oxalate & Calcium & $\mathbf{P}$ & 1 \\
\hline Oxalate & Lead & $\mathbf{P}$ & 2 \\
\hline Tetrapheny1 borate & Halide, silver/sulfate & $\mathbf{P}$ & 3 \\
\hline Nitrilotriacetic acid & Copper & $\mathbf{P}$ & 4 \\
\hline $\begin{array}{l}\text { Ethylenediamine, } \\
\text { tetraethylene pentanine, } \\
5,6 \text {-dimethy } 1-1,10 \text {-phenanthroline }\end{array}$ & Copper (non-aqueous) & $\mathbf{P}$ & 6 \\
\hline $\begin{array}{l}\text { Tetraethylene pentamine, } \\
\text { 1,10-phenanthroline, EDTA }\end{array}$ & Copper (aqueous) & $\mathbf{P}$ & 7,8 \\
\hline $\begin{array}{l}\text { EDTA, 8-hydroxyquinoline } \\
\text { nitrilotriacetic acid }\end{array}$ & Cadmitum & $\mathbf{P}$ & 5 \\
\hline Citrate & Copper & $\mathbf{P}$ & 9 \\
\hline Substituted benzoates, & Nitrate, perchIorate & $\mathbf{D}$ & 14 \\
\hline Salicylate & $\begin{array}{l}\text { Calcium ISE barrel, } \\
\text { spectal organic phase }\end{array}$ & $\mathbf{D}$ & 12 \\
\hline $\begin{array}{l}\text { Acetate, formate, propionate, } \\
\text { oxalate, benzoate, salicylate, } \\
\text { m- and p-toluenesulfonate }\end{array}$ & $\begin{array}{l}\text { Calcium ISE barre1, } \\
\text { speclal organlc phase }\end{array}$ & $D$ & 10,11 \\
\hline Picrate & $\begin{array}{l}\text { Calclum ISE barre1, } \\
\text { special organic phase }\end{array}$ & $\mathbf{D}$ & 13 \\
\hline $\begin{array}{l}\text { Trytophane, phenylalanine, } \\
\text { leucine, methionine, valine, } \\
\text { glutamic acid }\end{array}$ & $\begin{array}{l}\text { Calcium ISE barrel, } \\
\text { special organic phase }\end{array}$ & $\mathbf{D}$ & 20 \\
\hline Trifluoroacetate & $\begin{array}{l}\text { Specially prepared } \\
\text { electrode and organic } \\
\text { phase }\end{array}$ & $\mathbf{D}$ & 15 \\
\hline Malelc and phthalic acids & $\begin{array}{l}\text { Speclally prepared } \\
\text { electrode and organic } \\
\text { phase }\end{array}$ & D & 16,17 \\
\hline $\begin{array}{l}\text { Dehydroacetate, benzoate, } \\
\text { salicylate, p-hydroxybenzoate, } \\
\text { cyclohexylsulfamate, } \\
\text { o-benzosulfimide }\end{array}$ & $\begin{array}{l}\text { Specially prepared } \\
\text { electrode and organic } \\
\text { phase }\end{array}$ & D & 18 \\
\hline $\begin{array}{l}\text { Oxalate, acetate, benzoate, } \\
\text { salfcylate, leucine } \\
\text { phenylalanine }\end{array}$ & $\begin{array}{l}\text { Coated wire with } \\
\text { spectal organic } \\
\text { phase }\end{array}$ & D & 19 \\
\hline Tetrapheny 1 borate & $\begin{array}{l}\text { Phenolic-plasticized } \\
\text { nylon electrode }\end{array}$ & $\mathrm{D}$ & 21 \\
\hline
\end{tabular}

$a_{P}=$ potentiometric titration; $\mathbf{D}=$ direct emf measurement. 


\section{References}

1. A. K. Mukherj1, Analyt. Chim. Acta, 40, 354 (1968).

2. พ. Sel1 , Nicrochem. J., 15, 452 (1970).

3. E. S1ska and E. Pungor, Z. analyt. Chem., 257, 12 (1971).

4. G. A. Rechnitz and N. C. Kenny, Anal. Letters, 3, 509 (1970).

5. M. Mascint and A. Liberti, Analyt. Chim. Acta, 64, 63 (1973).

6. G. A. Rechnitz and N. C. Kenny, Anal. Letters, 2, 395 (1969).

7. J. W. Ross, Jr. and M. S. Frant, AnaZ. Chem., 41, 1900 (1969).

8. A. Vannt, Ann. Chim. (Rome), 63, 887 (1973); through Chem. Abstr., 83, 21380c (1975).

9. Orion Research, Inc., Applications Bulletin, 4th ed., p. 16 (1972).

10. C. J. Coetzee and H. Freiser, Anal. Chem., 40, 2071 (1968).

11. C. J. Coetzee and H. Freiser, AnaZ. Chem., 41, 1128 (1969).

12. W. M. Haynes and J. H. Wagenknecht, Anal. Letters, 4, 491 (1971).

13. S. G. Back, Anal. Letters, 4, 793 (1971).

14. R. F. Hirsch and G. M. O1derman, Anal. Chem., 48, 771 (1976).

15. N. Ishibashi and A. Jyo, Microchem. J., 18, 220 (1973).

16. N. Ishibasht, A. Jyo, and M. Yonemitsu, Chem. Lett., 1973, 483.

17. A. Jyo, M. Yonemitsu, and N. Ishibashi, BuZZ. Chem. Soc. Japan, 46, 3734 (1973).

18. T. Shigematsu, A. Ota, and M. Matusi, BulZ. Inst. Chem. Res., Kyoto Univ., 51, 268 (1973); cf. Chem. Abstr., 81, 72303w (1974).

19. H. James, G. Carmack, and H. Fretser, Anal. Chem., 44, 856 (1972).

20. M. Matsui and H. Freiser, AnaZ. Letters, 3, 161 (1970).

21. T. Higuchi, C. R. Illian, and J. L. Tossounian, Anar. Chem., 42, 1674 (1970). 


\section{Cations}

\section{Metals}

For a thorough treatment of the analysis of metals in organic compounds the reader is referred to the monograph by Gorsuch. ${ }^{1}$ No papers have appeared so far on these analyses using ISE's. This may be due to the obvious ease of applicability of these methods to organic compounds. The choice of mineralization depends on the metal to be analyzed. The oxygen-flask method, attractive in its simplicfty, may be used for materials which volatilize readily and do not react with the material of support. Otherwise wet combustion procedures are preferred. MacDonald and Sirichanya ${ }^{2}$ found the oxygen-flask method suitable for the determination of calcium, magnesium, zinc, barium, manganese, and cobalt. Wet-combustion procedures were recommended, however, for compounds containing nickel, copper, iron, and bismuth.

Since it is rather unusual for an organic compound to contain more than one metal, the final measurement will not normally require high selectivity and one can take advantage of the widely applicable EDTA titrations. only a few methods for determining cations with several complexing agents and ISE's as endpoint detectors w111 be mentioned here.
Ross and Frant ${ }^{3}$ used a copper ISE as endpoint detector in the titration of zinc, copper, nickel, lead, calcium, and cadmium. The titrants were EDTA, tetraethylene pentamine, and 1,10-phenanthroline. A copper(II)ligand complex was added to copperfree solutions to serve as indicator. This method is based upon the pritciple of detecting a metal ion displaxed from its EDTA complex. The petentiometric titrax ton makes use of the ability of the copper ISE to detect copper ions displaced from the Cu(II)-EDTA complex. The authors aiso discuss pH-potentfal plots that allow the prodiction of the $\mathrm{pH}$ at which opti-num endpoint breaks are obtained for a given fon and titrant. Proper choice of $\mathrm{pH}$ makes differential titratfons of several metal ions possible; $\mathrm{pH}$ adjustment also can mask interfering ions.

Baumann and Wallace ${ }^{4}$ extended the work of Ross and Frant ${ }^{2}$ to the titration of thorium, zirconium, iron, lanthanum, samarium, and mercury. Titrations were performed with EDTA, also using the $\mathrm{Cu}$ (II)-EDTA complex to serve as indicator, and the copper ISE as endpoint detector. This method is considered valid for the determination of most metal lons that form chelates wIth EDTA.

Moya and Cheng ${ }^{5}$ titrated varfous divalent and trivalent metal ions with triethylenetetramine hexaacetic 
Table 32. The determination of cations using ISE's.

\begin{tabular}{|c|c|c|c|c|}
\hline ISE used & Titrant ${ }^{a}$ & Metals determined & TItration method & Reference \\
\hline Copper & $\begin{array}{l}\text { EDTA } \\
\text { TEPA } \\
1,10 \text {-Phenan- } \\
\text { throline }\end{array}$ & $\underset{\mathrm{Cd}}{\mathrm{Zn}, \mathrm{N} I,} \mathrm{~Pb}, \mathrm{Ca}, \mathrm{Cu}$, & $\begin{array}{l}\text { Direct } \\
\mathrm{Cu}(I I)-\text { EDTA }\end{array}$ & 3 \\
\hline Copper & EDTA & $\begin{array}{l}\mathrm{Th}, \mathrm{Zr}, \mathrm{Fe}, \mathrm{La}, \mathrm{Sm}, \\
\mathrm{Ca}, \mathrm{Hg}\end{array}$ & $\mathrm{C}_{\mathrm{U}}(\mathrm{II})-\mathrm{EDTA}$ & 4 \\
\hline $\begin{array}{l}\text { Divalent } \\
\text { cation, } \\
\text { calcium }\end{array}$ & TTHA & $\begin{array}{l}\text { Practically all } \\
\text { polyvalent } \\
\text { cations }\end{array}$ & $\begin{array}{l}\text { Back-titration } \\
\text { preferred }\end{array}$ & 5 \\
\hline Iodide & $\mathrm{NaI}$ & $\mathrm{Hg}$ & Direct & 6 \\
\hline Calcium & EDTA & $\mathrm{Ca}$ and/or $\mathrm{Mg}$ & Direct & 7 \\
\hline
\end{tabular}

$a_{\text {TEPA }}=$ Tetraethylese pentamine; TTHA = Trlethylenetetramine hexacetic acid.

acid. Back-titration with standard solutions of lead, zinc, or calcium was the preferred method; practically all polyvalent cations can be determined by this method. Endpoints were detected by use of divalent cation ISE of a calcium ISE. No organic solvents can be used to improve the sharpness of the endpoints since the liquid lon-exchangers are soluble in most organic solvents.
Overman ${ }^{6}$ has used an iodide ISE for the potentiometric titration of mercury(II) with sodium todide. Calcium and/or magnesium have been determined by titration with EDTA using a calcium ISE. 7

A summary of the methods for most of the metal ions likely to be encountered in organic compounds is given In Table 32 .

\section{References}

1. T. T. Gorsuch, "Organic Analysts: Determination of Other Elements," in Treatise on Analytical Chemistry, Part II, Vo. 12, I. M. Kolthoff and P. J. Elving, Eds. (Interscience, New York, 1965), p. 295.

2. A. M. G. MacDonald and P. Sirichanya, Microchem. J., 14, 199 (1969).

3. J. W. Ross, Jr. and M. S. Frant, AnaZ. Chem., 41, 1900 (1969).

4. E. W. Baumann and R. M. Wallace, Anat. Chem., 41, 2072 (1969).

5. E. A. Moyra and K. L. Cheng, Anal. Chem., 42, 3.669 (1970).

6. R. F. Overman, Anal. Chem., 41, 616 (1971).

7. T. P. Hadf1loannou and D. S. Papastathopoulos, Tatanta, 17, 339 (1970). 
Nitrogen as Ammenivm Im

$A$ review of the KJeldahl method for the determination of nitrogen in organic compounds was recently published by Bradstreet. 1 In this method, the sample is oxidized by digestion with sulfuric acid. Carbon and hydrogen are expelled as carbon dioxide and water, wile the nitrogen present in aminoid linkages is converted and retained in the digest as ammonia. Non-aminoid nitrogen may require modified procedures for quantitative conversion to ammonia. Mercuric ion is usually employed as catalyst, although many others have been recommended. When the conversion of nj.trogen to ammonia is complete, the digest is made alkaline and the ammonia is distilled into standard acid for determination.

The distillation step in the nitrogen analysis of soll has been eliminated by using an ammonia ISE (Orion 95-10) for the determination of the amonium ion formed by digestion of the soil sample. ${ }^{2}$ A calibration curve was constructed by using aliquots of an ammonium standard in the required analytical range and treat-
Ing in the same fashion as the sample. After adding alkali, the pH was 13.0 to 13.2. The ammonium analysis of the digests and standards by the ISE procedure should be performed soon after adding alkali because ammonium fon may be lost as ammonia gas if samples are allowed to stand too long. Since mercuric 1on, usually used as catalyst In the Kjeldahi procedure, forms a complex with ammonia in alkaline solutions, it should be removed by addition of sodium 1odide. Bremer and Tabatabai, ${ }^{2}$ however, have used a selenium catalyst in their procedure.

The ISE method can of course also be applied to the determination of organic nitrogen directly in the digest by the Kjeldahl procedure. ${ }^{3}$

Deschreider and Meaux ${ }^{4}$ carried out a statistical study to compare the determination of ammonia nitrogen after Kjeldahl digestion by the Orion ammonia electrode (95-10) with the usual Kjeldahl method. The repeatability and agreement between methods as applied to agricultural products was acceptable; the permissible error was not exceeded.

\section{References}

1. R. B. Bradstreet, The KjeZdahl Method for Oxganic Nitrogen, Academic Press, New York, 1965.

2. J. M. Bremer and M. A. Tabataba1, Comm. Soil Sci. Plant Anal., 3, 159 (1972).

3. Orion Research, Inc., Newsietter, 4, 17 (1972).

4. A. R. Deschreider and R. Heaux, Analusis, 2, 442 (1973). 


\section{Oranic Catiow}

Detergent cations are treatea in a separate section, together with their respective antons. We have chosen the work of Rechnitz and Kugler ${ }^{1}$ as the starting point in reviewing the literature for applications of ISE's to the analysis of cations. These workers used a cation-sensitive glass electrode (Beckman 39137) and a fiberjunction SCE for measurement of alkylsubstituted ammonium fons. The substituted ammonium salts were prepared by neutralization of the corresponding hydroxides. They were then dissolved in a $0.1 \mathrm{M}$ buffer mixture of tris (hydroxymethy1)aminomethane and hydrochloric acid in order to maintain a constant $\mathrm{pH}$ of 8.9 and a constant ionic strength. The glass electrode was conditioned by soaking in the test solution for at least 48 hours. Emf's were monitored until a steady value was obtained; this time varied from a few seconds for the ammonium Ion to 20 hours for the largest cation tested. The ions investigated were methylammonium, dimethylammonium, trimethylammonium, ethylammonium, and diethylammonium. Increasing the ion size resulted in decreasing electrode sensitlvity, progressively greater deviation from Nernstian response (as shown in Table 33), and increasing equilibration times. Direct potentiometric measurement should be suftable for estimating smaller alkyl- substituted ammoniun lons in the presence of multivalent cations to concentrations of at least $10^{-2} M$. Vansant et al. ${ }^{2}$ determined some organic onfum ions by direct potentiometry. A liquid-membrane amonium ion electrode (Philip IS 560) was used over the range of $10^{-1}$ to $10^{-5} \mathrm{M}$, at $\mathrm{pH} 5.5 \pm 0.5$. The selectivity with respect to Interfering ions decreased in the following order:

$\mathrm{Bu}_{4} \mathrm{~N}^{+}>$cyclohexylammonium $>\mathrm{NH}_{4}{ }^{+}$

$>\mathrm{BuNH}_{3}^{+}>\mathrm{PrNH}_{3}^{+}>\mathrm{K}^{+}$piperidinium $>\mathrm{EtNH}_{3}^{+}>\mathrm{MeNH}_{3}^{+}>\mathrm{Me}_{2} \mathrm{NH}_{2}^{+}>\mathrm{Et}_{4} \mathrm{~N}^{+}$ $>\mathrm{Cs}^{+}>\mathrm{Na}^{+}>\mathrm{Me}_{3} \mathrm{NH}^{+}>\mathrm{Me}_{4} \mathrm{~N}^{+}$.

The response curves for the different cations demonstrate a nearly constant sensitivity. A linear relationship exists between the zero-potential and the molecular welght or polarizability of the cations within a homologous series. The authors suggest that this

Table 33. Response characteristics of glass electrode. ( $\quad(\mathrm{pH}$ 8.89 , temp. $30.0^{\circ} \mathrm{C}$ )

\begin{tabular}{lcc}
\hline \multicolumn{1}{c}{$\begin{array}{c}\text { Slope of ERF } \\
\text { vs } \begin{array}{c}\text { log conc. plot, } \\
\text { mV/decade }\end{array}\end{array}$} & $\begin{array}{c}\text { Selectivity } \\
\text { ratlo compared } \\
\text { to } \mathrm{NH}_{4}^{+}\end{array}$ \\
\hline $\mathrm{NH}_{4}^{+}$ & 64.62 & 1 \\
$\mathrm{CH}_{3} \mathrm{NH}_{3}^{+}$ & 55.70 & $1.86 \times 10^{-2}$ \\
$\mathrm{CH}_{3} \mathrm{CH}_{2} \mathrm{NH}_{2}^{+}$ & 49.3 & $6.60 \times 10^{-4}$ \\
$\left(\mathrm{CH}_{3}\right)_{2} \mathrm{NH}_{2}^{+}$ & 22.40 & $2.10 \times 10^{-4}$ \\
$\left(\mathrm{CH}_{3} \mathrm{CH}_{2}\right)_{2} \mathrm{NH}_{2}^{+}$ & - & $1.40 \times 10^{-4}$ \\
$\left(\mathrm{CH}_{3}\right)_{3} \mathrm{NH}^{+}$ & 22.00 & $9.60 \times 10^{-5}$ \\
\hline
\end{tabular}


electrode may find use in biological, clinical, and pollution applications. Collier ${ }^{3}$ found the cyclohexylammonium cation to interfere with the Orion calcium (92-20) and Orion divalent cation (92-32) electrodes. In fact, these electrodes gave a Nernstian response of $59 \mathrm{mV}$ per decade to this ion over the range of 1 to $10^{-3} M$. The cations of choline, triethanolamine, and tris (hydroxylmethy1) aminomethane, however, had no effect upon the potentials.

Tetraphenylarsonium cation may be titrated potentiometrically with perchlorate ${ }^{4}$ or tetrafluoroborate. 5 The appropriate anion-selective electrodes can be used to monitor the course of the titrations. In the titration with perchlorate, best results are obtalned with solutions between $\mathrm{pH} 4$ and 7 . With both titrants, sharper titration curves are obtained at $2{ }^{\circ} \mathrm{C}$ owing to the lower solubilities of the resulting salts.

Sharp and Johansson ${ }^{6}$ have studied some semiconducting organic radicalIon salts with regard to potential use in solid-state ISE's. ISE's were prepared from $7,7,8,8$-tetracyanoquinodimethane (TCNQ) and futund suitable for a wide range of organic, organometallic, and metallic cations. Thus the tetraethylammonfum compound resulted in an electrode selective for this sation compared to ammonium and other tetraalky lammontum tons.
The same was true for the tetraphenylarsonfum electrode. Tetraethylambrifum lons were determined over the range of $10^{-1}$ to $10^{-5} \mathrm{M}$ at various $\mathrm{pH}$ by direct potentiometry. The $\mathrm{pH}$ was adjusted with hydrochloric acid and TRIS buffer. The $\mathrm{pH}$ dependence of the electrode was relatively slight, amounting to $6 \mathrm{mV} /$ decade at the higher concentration, and $1 \mathrm{mV} /$ decade at $10^{-5} \mathrm{M}$. In order to minimize the interference of hydrogen Ions the $\left(\mathrm{C}_{2} \mathrm{H}_{5}\right)_{4} \mathrm{~N}^{+}$concentration should be at least 10 times higher than the hydrogen ion concentration.

The tetraphenylarsonium ion showed a linear response over the same concentration range. However, the slope, $40 \mathrm{mV} /$ decade, was significantly lower than the Nernstian. Response times seemed to be determined by the solubility of the electrode material; the higher the solubility, the slower the attainment of equilibrium.

In a subsequent paper, Sharp ${ }^{7}$ investigated additional radical-anion salts, namely those of $11,11,12,12-$ tetracyanonaphtho-2,6-quinodimethane (I), 9-dicyanomethylene-2, 4,7trinitrofluorene (II), and 2,4,5,7tetranitro- $\Delta^{9 \alpha}$-malononitrile (III). The Ifthlum salts of these three radical anions are sufficiently soluble in methanol and water to allow synthesis of other radical anion salts by direct metathesis, the required products being precipitated. Electrodes 
were made from the tetraphenylarsonium (as well as some cation) salt of the radical-anton. Response characteristlcs were determined in unbuffered aqueous solutions of tetraphenylarsonium chloride. Electrodes functioned almost Imanediately on immersion in the test solution; thus pre-soaking was not required. Response times were usually less than $3 \mathrm{~min}$. Electrodes were stored dry for up to 3 months without serious deterioration in properties. Reproducibility for a series of measurement was within $\pm 2 \mathrm{mV}$. Unlike the electrodes made from TCNQ, ${ }^{6}$ essent lally Nernstian response curves were obtained from $10^{-1}$ to $10^{-6} M$. It seems, therefore, that by using salts of a radicalanton with a higher molecular weight than TCNQ as electrode sensor, lower solubility and Improvement in operational activity range results. The heavy metal tons silver(I) and mercury(II) interfere strongly by formation of the corresponding insoluble salts on the electrode surfaces.

The tetraphenylarsontum electrode may be used as indicator electrode in the potentfometric titration of perchlorate, as shown in FIg. 14. The reverse titration of $\left(\mathrm{C}_{6} \mathrm{H}_{5}\right)_{4} \mathrm{As}^{+}$with perchlorate obviously is also feasIble.

Baum $^{8}$ has described the performance characteristics of a liquid membrane ISE for the acetyIcholine cation. The electrode was a corning No. 476200 model. HIgh selectivity over choline, sodium, potassium, and anmonium Ions was observed. The response of the electrode was linear from $10^{-1}$ to $10^{-4} \mathrm{M}$, with a Nernstian slope of $59 \mathrm{mV}$. A simtlar electrode for choline showed also a linear response over the same concentration range; the slope, however, was only $54 \mathrm{mV}$. The response time of the acetylcholine electrode was quite

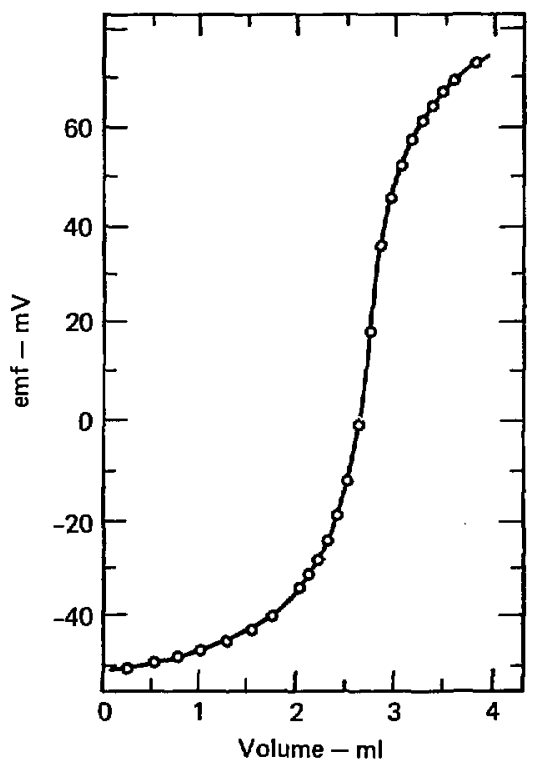

Fig. 14. Potentiometric titration of $25.0 \mathrm{ml}$ of aqueous $\mathrm{NaClO}_{4}(0.005 \mathrm{M})$ with aqueous $\left(\mathrm{C}_{6} \mathrm{H}_{5}\right)_{4} \mathrm{AsCl}^{4}(0.0466 \mathrm{M})$ for a $\left(\mathrm{C}_{6} \mathrm{H}_{5}\right)_{4} \mathrm{As}$ (DTF) electrode. The calculated equivalent volume of tItrant = observed equivalent volume = $2.68 \mathrm{ml}$. Source: Ref. 7 , used with permission. 
rapid even at low concentrations, on the order of 10 to $20 \mathrm{~s}$. In the presence of inorganic cations, however, the response was sluggish, requiring up to 20 minute to reach equilibrium. The selectivity ratio for acetylcholine over choline was 15:1.

Higuchi et $a 2^{9-11}$ have developed simple plastic membrane electrodes for relatively hydrophobic organic cations and anions. This has been discussed also in the section on orginic anions (p. 51). Nearly any organic plastic matrix of limited hydrophilicity can be used as the gelling agent of the membrane. The response time of these electrodes was rapid; stable emf's were obtained in less than $1 \mathrm{~min}$ for concentrations greater than $10^{-5} \mathrm{M}$.

A polyvinyl chloride (PVC) membrane plasticized with $\mathrm{N}$, N-dimethyloleamide (Hallcomid 18-OL) shows a Nernstian response to tetrabutylammonium ion but not to potassium ion. Unfortunately, this electrode cannot be used in aqueous solution because of its response to hydrogen Ion: amides are relatively good proton carriers.

This sensitivity toward hydrogen Ion, however, is not present in PVC plasticized with dioctylphthalate. The excellent Nernstian response of this electrode toward cations is evident from Fig. 15. This figure also shows the role of hydrophobic or 1fpophilic forces in determining the sensitivity and specificity of these electrode systems. For example, the response to the tetrahexylammonfum ion Is consistently $350 \mathrm{mV}$ greater than that to the tetrapropylanmonium ton.

Some practical applications of the plastic membrane electrodes are in titrimetric analysis. Thus, a PVCamide-indicating electrode may be used in the potentiometric titration. of the drug diphenydramine and dextromethorphanium cations with the tetraphenylboron anion. In the titration of equimolar mixtures of tetrahexyl- and tetrabutylammonium bromide with sodium tetraphenylboron, two breaks occur with a PVC-dioctylphthalate electrode. ${ }^{12}$ This can also be extended to ternary mixtures of

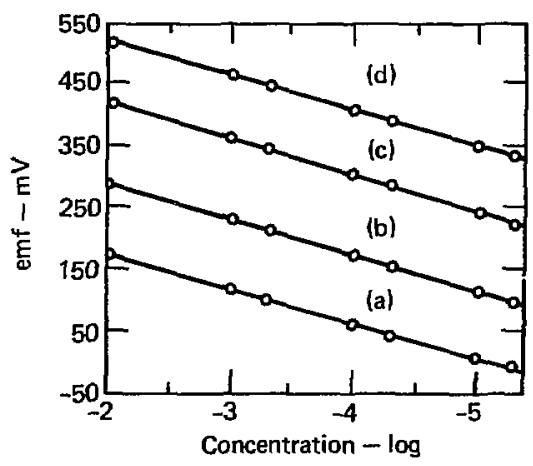

Fig. 15. Response of PVC-DOP membrane to quaternary ammonium lons.

(a) Tetrapropylammonium: slope $=-57.5$.

(b) Tetrabutylammonium: slope $=-58.5$.

(c) Tetrapenty.1 ammonium: slope $=-59.5$.

(d) Tetrahexylammonium: slope $=-58.5$. Source: Ref. 9, used with permission. 
tetrahexy 1-, tetrabuty1-, and tetraethylammonium bromide, as shown in Fig. 16.

Scholer and Stmon ${ }^{13}$ used an $\mathrm{Ag} / \mathrm{AgCl}$ electrode (containing $0.01 \mathrm{M}$ cestur chloride) with a liquid ionexchanger membrane for the direct determination of a large variety of onium ions. The membrane was prepared from a mixture of $2 \%$ sodium tetraphenylboron and $1 \%$ thenoyltrifluoroacetone in p-nitrocymene, and poly (vinylchloride) in tetrahydrofuran. In general, the electrodes showed Nernstian response at $>10^{-6} \mathrm{M}$ cation activities and had lifetimes of at least 4 months. Strong deviations from Nernstian response were observed with such small cations as potassium and cesium. On decreasing the cation concentration from $10^{-2}$ to $10^{-3} \mathrm{M}$, stable emf's were obtained within $60 \mathrm{~s}$, reproducible to $\pm 0.5 \mathrm{mV}$. Conditioning the electrodes by immersion in the appropriate cation solutions is recommended. The selectivity constants of the cations correlate closely with the exchange constants of the corresponding extraction of the onium Ion as an ion pair with the tetraphenylborate anfon. The selectivity constants for a large number of

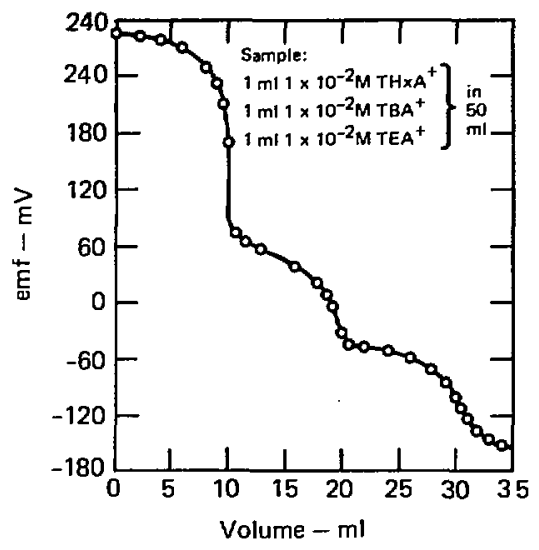

Fig. 16. Titration of a mixture of $\mathrm{THxA}^{+}, \mathrm{TBA}^{+}$, and $\mathrm{TEA}^{+}$bromides. The titrant is $1 \times 10^{-3} \mathrm{M} \mathrm{Na}$ TPB.

Source: Ref. 12, used with permisston.

onium ions are given; a few examples of these onium lons are $\left(\mathrm{CH}_{3}\right)_{4} \mathrm{~N}^{+},\left(\mathrm{CH}_{3}\right)_{2}\left(\mathrm{C}_{16} \mathrm{H}_{33}\right)^{+} \mathrm{NCH}_{2} \mathrm{C}_{6} \mathrm{H}_{5}$, $\left(\mathrm{C}_{5} \mathrm{H}_{5}\right)_{4} \mathrm{P}^{+},\left(\mathrm{C}_{6} \mathrm{H}_{5}\right)_{4} \mathrm{As}^{+}$, guanidinium, choline, acetylcholine, succinylcholine, tropine, scopolamine, atropine, methylene blue, gentian violet, and tetrazolium blue.

A summary of methods for organic cations is presented in Table 34. 
Table 34. Summary of methods for organic cations using ISE' $\theta$.

\begin{tabular}{|c|c|c|c|}
\hline Cation & Electrode & Method ${ }^{a}$ & Reference \\
\hline $\begin{array}{l}\text { Methyl-, dimethyl-, and } \\
\text { trimethylammonium, ethyl-, } \\
\text { and diethylamonium }\end{array}$ & Beckman 39137 & D & 1 \\
\hline Organic onium Ions & $\begin{array}{l}\text { Liquid-membrane } \\
\text { ammonium electrode }\end{array}$ & D & 2 \\
\hline Cyclohexylammonium & $\begin{array}{l}\text { Calcium divalent } \\
\text { cation }\end{array}$ & D & 3 \\
\hline Tetraphenylarsontum & $\begin{array}{l}\text { Perchlorate } \\
\text { tetrafluoroborate }\end{array}$ & $\mathbf{P}$ & 4,5 \\
\hline $\begin{array}{l}\text { Tetraethylammonium } \\
\text { Tetrapheny larsonium }\end{array}$ & $\begin{array}{l}\text { Solid state TCNQ and } \\
\text { other salts }\end{array}$ & $\stackrel{D}{D, P}$ & 6,7 \\
\hline $\begin{array}{l}\text { Acetylcholine } \\
\text { Choline }\end{array}$ & Corning 476200 & D & 8 \\
\hline $\begin{array}{l}\text { Diphenhydramine } \\
\text { Dextromethorphanium }\end{array}$ & $\begin{array}{l}\text { PVC-amide plastic } \\
\text { electrode }\end{array}$ & $\mathbf{P}$ & 9,12 \\
\hline $\begin{array}{l}\text { Tetrapropy lammonium } \\
\text { Tetrabutylammonium } \\
\text { Tetrapentylammonium } \\
\text { Tetrahexylammonium }\end{array}$ & $\begin{array}{l}\text { PVC-amide plastic } \\
\text { electrode }\end{array}$ & $\mathrm{D}$ & 9,12 \\
\hline Large number of onium lons & $\begin{array}{l}\text { Liquid Ion-exchange in } \\
\text { PVC membrane }\end{array}$ & D & 13 \\
\hline
\end{tabular}

\section{References}

1. G. A. Rechnitz and G. Kugler, Z. analyt. Chem., 210, 174 (1965).

2. E. P. Vansant, H. Deelstra, and R. Dewolfs, Talanta, 21, 608 (1974́).

3. H. B. Collier, Anal. Chem., 42, 1443 (1970).

4. R. J. Baczuk and R. J. DuBois, Anal. Chem., 40, 685 (1968).

5. M. J. Smith and S. E. Manahan, Analyt. Chim. Acta, 48, 315 (1969).

6. M. Sharp and G. Johansson, Analyt. Chim. Acta., 54, 13 (1971).

7. M. Sharp, Analyt. Chim. Acta., 59, 137 (1972).

8. B. Baum, Analyt. Letters, $\underline{3}, 105$ (1970). 
9. T. H1guch1, C. R. Illian, and J. I. Tossountan, AnaI. Chem., 42, 1674 (1970).

10. T. Higuch1, U.S. Pat. 3,843,505 (22 0ct. 1974); cf. Chem Abstr., 82, $25497 y$ (1975).

11. T. Higuch1, U.S. Pat. 3,843,490 (22 0ct. 1974); cf. Chem Abstr., 82, 25501y (1975).

12. C. R. Illian, from Diss. Abstr. Int $B$, 32, 2045 (1971); cf. Chem Abstr., 76, 67335a (1972).

13. R. Scholer and w. Simon, Helv. Chim. Acta, 55, 1801 (1972). 


\section{Surfactants and Detergents}

This section deals with long-chain organic cations and anions not found in earlier sections.

Botré et al. ${ }^{1}$ reported emf measurements in cells containing ionexchange membranes to determfne the activitles of fonlc surfactants in solution. The test solutions were sodium dodecyl sulfate (SDS) and cetyl pyridinium bromide (CPB). For SDS and $C P B$ alone, and for SDS in the presence of menthol, octanol, and decanol, Nernstian response was obtained below the critical micelle concentration (c.m.c.). Non-Nernstian response was obtained for SDS plus hexamethylenetetramine. Both SDS and CPB Interacted with the polyethylene glycol Carbowax 4000.

Shirahama ${ }^{2}$ measured the membrane potentials of sodium dodecyl sulfate solutions produced by anion as well as cation-exchange membranes. The results were interpreted in the light of the current theory of micellar solutions. As above, the slope agrees we11. with the Nernstlan below the c.m.c.

Birch and clarke ${ }^{3}$ described an electrode selective to the dodecyl sulfate fon. The barrel of an orion calcium electrode was used; the 1.1quid phase contained $10^{-3} M$ cety1 trimethylawonium dodecylsufate in nitrobenzene. A millipore filter disc was used as an Inert porous matrix for the 11quid lon-exchanger.

Emf's reached their steady value $( \pm 0.2 \mathrm{mV})$ within $30 \mathrm{~s}$; electrode drift was less than $1 \mathrm{mV} / \mathrm{day}$. Electrodes selective to other surfactant Ions can be obtained by the suttable cholce of the anionic-cationic complex. As shown in Fig. 17, near Nernstian response is ot:alned for $5 \times 10^{-5}$ to $5.6 \times 10^{-3} \mathrm{M}$. The change In response at this point implies that the c.m.c. has been reached. Nevertheless, the authors disagree with Gavach and Bertrand ${ }^{4}$ (see below) that ISE's may be used for the determination of c.m.c.'s.

Gavach and Bertrand ${ }^{4}$ described the construction of liquid membrane electrodes specific for dodecylsulfate, tetrapropylene benzenesulfonate, and dioctylsulfocuccinate. The sodium

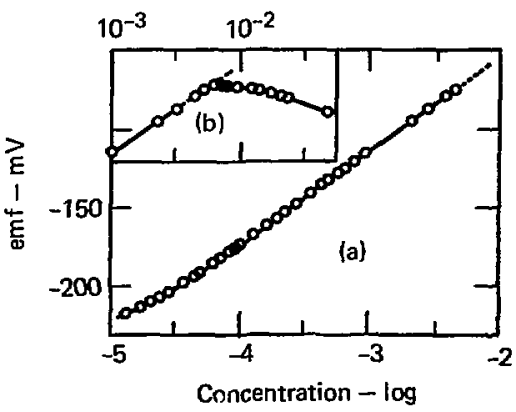

Fig. 17. Response of the DS ${ }^{-}$electrode to (a) change in $\mathrm{DS}^{-}$activity below the c.m.c. and (b) change in DS concentration above the c.m.c. Source: Ref. 3, used with permission. 
salts of these antons are common detergents. If the sodium is replaced by a long-chain alkylpyridinium cation, the resulting salt is soluble in nitrobenzene but insoluble in water. Electrodes made from this salt respond both to the alkylpyridinium cation and to the anionic detergent in aqueous solution down to $5 \times 10^{-6} M$. Electrodes for one detergent anion respond in a non-Nernstian manner to other detergent anions and also to sodium chlorlde. Since emf's show little variation in the micellar region (see Fig. 17 above), the authors believe that the c.m.c. can be thus determined.

Besides the direct enf measurement, anionic detergent solutions can also be titrated potentiometrically with hexadecylpyridinium bromide as titrant. An excess of sodium chloride can be tolerated. The total anionic detergent can also be titrated potentlometrically; however, no differentiation is possible.

Gavach and Seta ${ }^{5}$ determined the following cations by potentiometric titration in aqueous solution:

- Dodecyltrimethylammonium, DTA ${ }^{+}$. $\mathrm{TTA}^{+}$.

Tetradecyltrimethylammonium,

- Hexadecyltrimethylammonlum, $\mathrm{HTA}^{+}$. Tetrabutylamonium, $\mathrm{TBA}^{+}$.

Electrodes were constructed in a similar fashion to those previously described by Gavach and Bertrand ${ }^{4}$ for detergent antons. The picrates or tetraphenylborates of these cations are Insoluable in water; electrodes made from these salts in nitrobenzene respond to the cations. A description of the electrode construction is given elsewhere. 6

The cations $\mathrm{DTA}^{+}, \mathrm{TTA}^{+}$, and $\mathrm{TBA}^{+}$ can be titrated potentiometrically with either sodium tetraphenylborate, or sodium or potassium picrate. Larger potential breaks are obtalned with the tetraphenylborate. $\mathrm{HTA}^{+}$, however, can be titrated only with picrate because of the more 1ipophilic character of this cation.

For the titration of $\mathrm{DTA}^{+}$, $\mathrm{TTA}^{+}$, and $\mathrm{TBA}^{+}$, the lower limit is near $10^{-6} M$ with $0.01 M$ titrant. The precision depends on the cation concentration, ranging from $\pm 0.1 \%$ at $10^{-3} \mathrm{M}$ to $\pm 0.5 \%$ at $2 \times 10^{-6} M$. These cations can also be determined in the presence of an excess of salts such as sodium chloride, whose cations are not precipitated by the tetraphenylborate (shown in Fig. 18). However, even though potassium tetraphenylborate is insoluble in water, $\mathrm{DTA}^{+}$can be titrated in the presence of low concentrations $\left(10^{-3} M\right)$ of potassium ion.

The lower limit for the titration of $\mathrm{HTA}^{+}$with picrate is near $3 \times 10^{-5} M$. The preciston of this titration is less satisfactory, ranginf from $\pm 0.5 \%$ at $1 \mathrm{~m} M$ to $\pm 2 \%$ at $0.05 \mathrm{~m}$. 


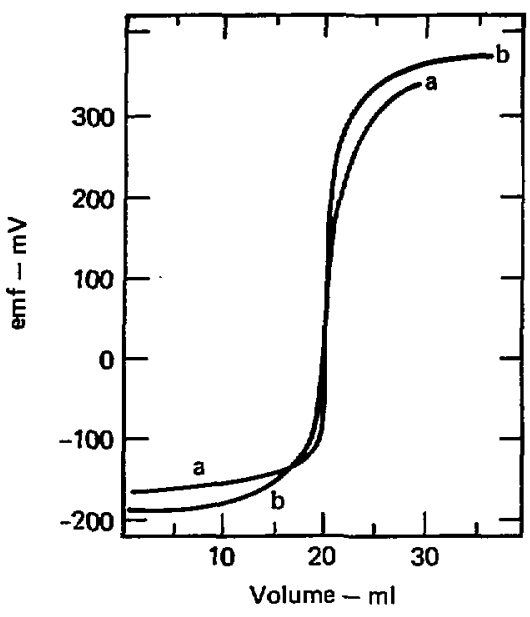

Fig. 18. Titration curve of $20 \mathrm{ml}$ of $10^{-3} M$ DTABr with $10^{-3} M$ sodium tetraphenylboron (a) in presence of $1 M \mathrm{NaCl}$ and (b) In presence of $10^{-3} \mathrm{M} \mathrm{KBr}$. Source: Ref.5, used with permission.

Birch and clark ${ }^{7}$ improved upon the previously described ${ }^{3}$ electrode selective for the dodecylsulfate anion. Nitrobenzene was replaced by o-chlorobenzene as the water-imniscible Ifquid since the latter has no effect on the c.m.c. of sodium dodecylsulfate. A variety of organic cations were synthesized; however, only an electrode based upon the hexadecylpyrIdinium cation yielded stable emf's. The electrode was also used as sensor for cationic surfactants. Thus, for tetradecyltrimethy lammontum bromide, a near-Nernstian response was obtalned. Sodium chloride, sodium sulfate, and sodium phosphate up to
$20 \mathrm{mH}$ did not interfere. Also, materials of shorter chain length did not Interfere with the dodecylaulfate electrode.

Electrodes were also made for the following anlonis surfactants with chain lengths from $C_{6}$ to $C_{14}$ : Sodiun dodecylbenzenesulfonate, sodium dodecylsulfonate, sodium dodeceny: sulfonate, sodium dodecylethersulfate, and sodium dodecanoate. Each of these electrodes yielded near-Nernstian behavior in solutions of the pure corresponding surfactants.

In another paper, Blrch and Clark 8 cast serious doubt on the thermodynamic validity of using permselective membranes to determine surfactant activitles. Furthermore, because emf's are slow to reach equilibrium, the use of perm-selective membranes is time-consuming and unsuitable for routine work. A further drawback is that these membranes are nonselective and, thus, cannot be used in mixed electrolyte solutions.

Birch et az. 9 evaluated a dodecylsulfate electrode in surfactant solutions contalning polymers and a protein. The results were used to construct surfactant Ion-binding isotherms that show similar regions of change to those previously estab1Ished by indirect methods.

Ishibashi et al. ${ }^{10}$ used tripheny1methane derivative cations and dociecyloctylmethylbenzylammontum Ion 
as the ion-exchange site in the 11quid membrane of electrodes responstve to aromatic sulfonates such as benzenesulfonate and $\alpha$-naphthalenesulfonate. The triphenylmethane derivatives were the benzenesulfonates of crystal violet, methyl violet, malachite green, and fuchsine basic. The nitrobenzene or 1,2-dichloroethane membrane containing the crysta1 violet-sulfonate pair had nearNernstian response down to $10^{-4} \mathrm{M}$ sulfonate. The enf of the crystal violet membrane was independent of $\mathrm{pH}$ variation from 2.5 to 12 . Chloride and sulfate in the aqueous sample did not affect the emf. The $\alpha$-napthalenesulfonate electrode was not affected by $1,3,6$-naphthalenetrisulfonate. However, the interference of nitrate was relatively large.

Fujinaga et al. ${ }^{11}$ tested a coatedwire ISE previous1y described by Cattra11 and Freiser ${ }^{12}$ in solutions of the anionic detergents p-toluenesulfonate, isolaurylbenzenesulfonate, n-1aury1benzenesulfonake, n-octy1sulfate, and lauryl sulfate. A configuration of the electrode is shown in Fig. 19. The electrode was initfally conditioned by soaking for 30 min in a $10^{-4} M$ solution of the anlon to be measured, and stored in air when not in use. It was reconditioned similarly for 5 min tmmediately before use. Equilibrium potentials sere usually achleved within 2 to $3 \mathrm{~min}$ and were reproducible whthin $\pm 0.1 \mathrm{mV}$. The usable concentration ranges for direct emf measurement and the slopes are given In Table 35. Chloride and sulfate Interfered very little, while nitrate, perchlorate and acetate interfered seriously. Selectivity ratios are given for these anions. No differentiation among the surfactants is possible. Kataoka and Kambara ${ }^{13,14}$ prepared an electrode for dodecylbenzenesulfonate (DBS ${ }^{-}$): $\mathrm{DBS}^{-}$forms an tonpair with tetradecyldimethylbenzylammonium cation (Zephiramine, $z^{+}$),

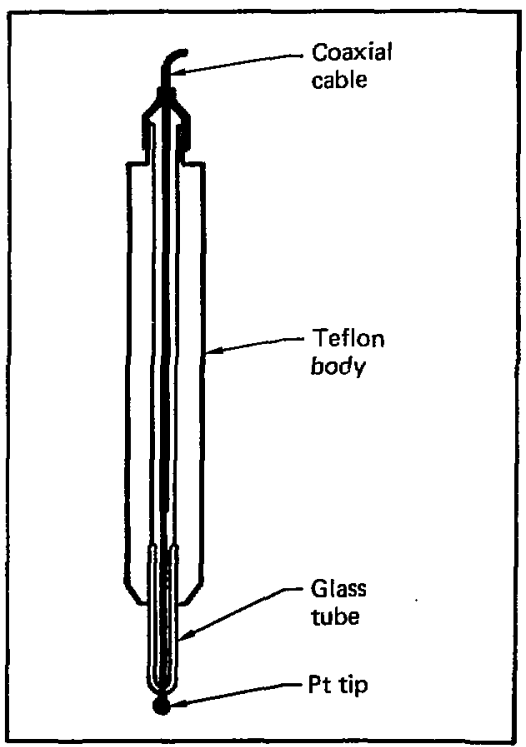

Fig. 19. Configuration of electrode. Source: Ref. 11, used with permisston. 
Table 35. Behavior of detergent-responsive electrodes.

\begin{tabular}{|c|c|c|c|c|c|}
\hline \multirow[b]{2}{*}{ Electrode } & \multirow[b]{2}{*}{$\begin{array}{l}\text { Slope, } \\
\text { mV }\end{array}$} & \multirow{2}{*}{$\begin{array}{l}\text { Concentration } \\
\text { range of } \\
\text { linear } \\
\text { response, } M\end{array}$} & \multirow[b]{2}{*}{$\begin{array}{l}\text { Usable } \\
\text { range, } M\end{array}$} & \multicolumn{2}{|c|}{ CMC } \\
\hline & & & & $\begin{array}{c}\text { Electrode, } \\
10^{-3}{ }_{M}\end{array}$ & $\begin{array}{c}\text { Surface } \\
\text { tension, } \\
10^{-3_{M}}\end{array}$ \\
\hline $\mathrm{p}-\mathrm{CH}_{3} \mathrm{C}_{6} \mathrm{H}_{4} \mathrm{SO}_{3}^{-}$ & 57 & $10^{-1}-10^{-3.6}$ & $10^{-1}-10^{-5}$ & - & - \\
\hline $\mathrm{I}-\mathrm{C}_{12} \mathrm{H}_{25} \mathrm{C}_{6} \mathrm{H}_{4} \mathrm{SO}_{3}^{-}$ & 55 & $10^{-3}-10^{-5}$ & $10^{-3}-10^{-5.5}$ & 1.6 & 1.7 \\
\hline $\mathrm{n}-\mathrm{C}_{12} \mathrm{H}_{25} \mathrm{C}_{6} \mathrm{H}_{4} \mathrm{SO}_{3}^{-}$ & 75 & $10^{-3}-10^{-4.7}$ & $10^{-3}-10^{-5.5}$ & 1.6 & 1.5 \\
\hline $\mathrm{n}-\mathrm{C}_{8} \mathrm{H}_{17} \mathrm{SO}_{4}^{-}$ & 55 & $10^{-1}-10^{-3.6}$ & $10^{-1}-10^{-5}$ & - & - \\
\hline${ }^{\mathrm{n}}-\mathrm{C}_{12} \mathrm{H}_{25} \mathrm{SO}_{4}^{-}$ & 89 & $10^{-2}-10^{-3.7}$ & $10^{-2}-10^{-5}$ & 12 & 10 \\
\hline
\end{tabular}

wich is extractable Into organic solvents. Naphthalene was added to the hot nitrobenzene extract of $\mathrm{z}^{+} \mathrm{DBS}^{-}$ion-pair and melted, then a platinum electrode was coated with the melt. A Nernstian response was obtained from $10^{-3}$ to $10^{-7} M \mathrm{DBS}^{-}$, and from $10^{-4}$ to $10^{-7} M \mathrm{z}^{+}$. The electrode had good selectivity for chloride, nitrate, and sulfate, and poor selectivity for perchlorate and dodecylsulfate. It can also be used as indicator in the potentiometric titration of $\mathrm{DBS}^{-}$with $\mathrm{Z}^{+} \mathrm{Cl}^{-}$, as shown in Fig. 20.

Tanaka et $a l^{15}$ prepared an a1kylbenzenesulfonate ISE by Incorporating the sulfonate-ferroin complex tnto a matrix of poly (vinyl chloride). This electrode can be used for direct enf detemination of from $10^{-2}$ to $10^{-6} \mathrm{M}$ alkylbenzenesulfonate. In the presence of $10^{-4} M$ sulfonate, the maximum permissible amounts of salts were $10 \mathrm{mM}$ potassium nitrate and potassium phosphate, $1 \mathrm{~m} M$ sodium chloride, and $0.1 \mathrm{~m} M$ ammoniun sulfate. It was

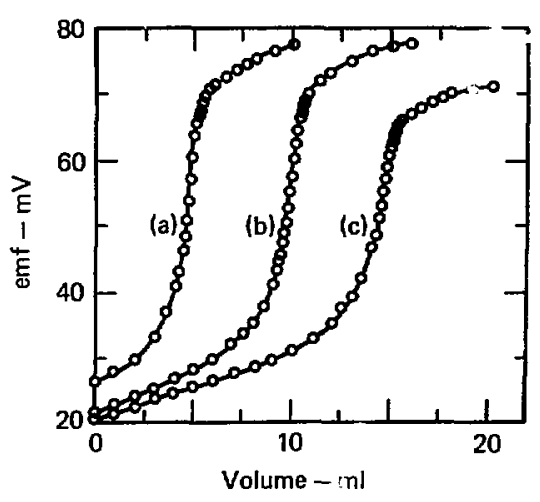

Fig. 20. Titration cuive of $\mathrm{DBS}^{-}$with fresh1y-prepared $1 \mathrm{~m}^{\mathrm{H}} \mathrm{z}^{+} \mathrm{Cl} 1^{-} ; 1 \mathrm{mM}$ DBS solution taken: (a) $5 \mathrm{ml}$; (b) $10 \mathrm{ml}$; and (c) $15 \mathrm{~m}$;. Water is added to 50-ml volume; temperature = $19^{\circ} \mathrm{C}$. Source: Ref. 13, used with permission. 
found that membranes contalning mixtures of the sulfonate-ferroin and perchlorate-ferroin complex showed faster response and less noise than those containing only the sulfonateferroin complex.

Popa et al. ${ }^{16}$ used an electrode with a liquid membrane consisting of a solution of cetylhexyldimethylammonium dodecylsulfate in nitrobenzene on a carbon support for the determination of the dodecylsulfate anion in aqueous solution. The useful range for the direct emf measurement was from $5 \times 10^{-3}$ to $10^{-5} M$.

Llenado ${ }^{17}$ investigated the response characteristics of a calcium ISE

(Orion 92-20) in the presence of linear alkylbenzenesulfonate (LAS) or disobutylphenoxyethy1 (dimethyl)benzylammonium chloride (Hyamine). Both surfactants interfered with the calcium ISE. LAS interfered by competing reactions between IAS and calcium ion at the organophilic membrane, and between calcium ions and the ionexchanger site. Hyamine interfered through the displacement of calcium ions in the ion-exchanger site. The Interference of IAS, however, could be overcome by loading the membrane phase with an equilibrium amount of LAS. The calcium ISE is considerabiy more selective to Hyamine than to calcium lons. This permits the use of the calcium ISE in the potentlometric titration of LAS with Hyamine, as shown in FIg. 21, or for the direct emf measurement of Hyamine and analogous spectes (aniontc surfactants).

Fogg et al. ${ }^{18}$ described siliconerubber electrodes responsive to cat $1-$ onic detergents. These electrodes do not respond to detergent anions. The most suitable electrodes contained $40 \%(w / w)$ of hexadecyltrimethylammonium dodecylsulfate in a silastomer matrix. Within $1 \mathrm{~min}$, a steady emf response was obtained within the range of $10^{-3}$ to $10^{-5} \mathrm{M}$ hexadecyltrimethylammonium bromide or hexadecylpyridiniun bromide. The slope was $56 \mathrm{mV}$

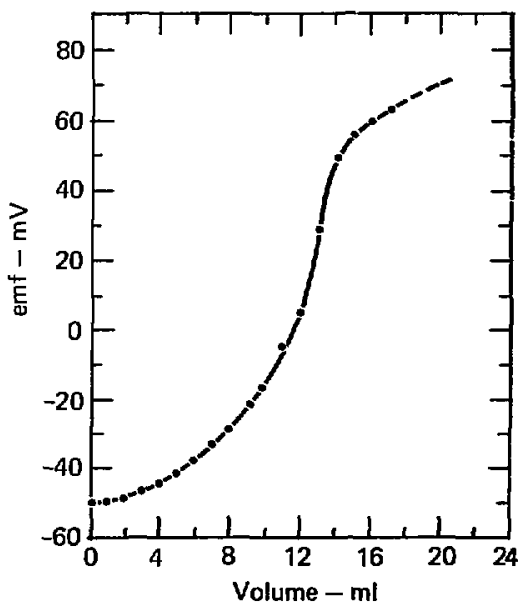

F1g. 21. Typical titration curve for LAS. A sample of LAS $\left(10^{-3} M\right)$ is titrated with a standard $0.1 M$ Hyamine. Source: Ref. 17, used with permission. 
Table 36. Summary of methods for surfactants using ISE's.

\begin{tabular}{|c|c|c|c|}
\hline Ion & Electrode $^{a}$ & Method ${ }^{b}$ & Reference \\
\hline Dodecylsulfate & Membrane & D & 1,2 \\
\hline Cetyl pyridinium & Membrane & $\mathbf{D}$ & 1 \\
\hline Dodecylsulfate & Calcium & D & $3,7,9,16$ \\
\hline $\begin{array}{l}\text { Dodecylsulfate, tetrapropvlene } \\
\text { benzenesulfonate, dioctylsulfo- } \\
\text { cucclnate, hexadecylpyridinium }\end{array}$ & & $D, P$ & 4 \\
\hline $\begin{array}{l}\text { Dodecyltrimethylammonium, } \\
\text { tetradecyltrimethylammonium, } \\
\text { hexacecyltrimethylammonium, } \\
\text { tetrabutylammonium }\end{array}$ & & $\mathbf{P}$ & 5 \\
\hline $\begin{array}{l}\text { Tetradecyltrimethylammonium } \\
\text { dodecylbenzenesulfonate, dodecy1- } \\
\text { sulfonate, dodecenylsulfonate, } \\
\text { dodecylethersulfate, dodecanoate }\end{array}$ & & $\mathbf{D}$ & 7 \\
\hline $\begin{array}{l}\text { Benzenesulfonate, } \\
\alpha \text {-naphthylsulfonate }\end{array}$ & $\cdot$ & D & 10 \\
\hline $\begin{array}{l}\text { p-Toluenesulfonate, isolauryl- } \\
\text { benzenesulfonate, n-1auryl- } \\
\text { benezenesulfonate, n-octoylsulfate, } \\
\text { laurylsulfate }\end{array}$ & Coated wIre & D & 11 \\
\hline $\begin{array}{l}\text { Dodecylbenzenesulfonate } \\
\text { zephiramine }\end{array}$ & & $\mathrm{P}, \mathrm{D}$ & 13,14 \\
\hline Alky1benzenesulfonate & PVC matrix & $\mathbf{D}$ & 15 \\
\hline $\begin{array}{l}\text { Linear alky lbenzenesulfonate, } \\
\text { hyamine }\end{array}$ & Calctum & $\mathrm{P}, \mathrm{D}$ & 17 \\
\hline $\begin{array}{l}\text { Hexadecy1trimethylammonium } \\
\text { dodecylsulfate, hexadecyl- } \\
\text { pyridintum }\end{array}$ & Stlicone rubber & $P, D$ & 18 \\
\hline
\end{tabular}

\footnotetext{
${ }^{a_{A l l}}$ electrodes contain a specially prepared organtc phase.

$b_{D}=$ direct emf measurement; $P=$ potentiometric titration.
} 
per decade. Electrodes containing larger amounts of surfactant material responded much mare slowly. The electrodes can also be used as endpoint detectors in the potentiometric titration of cationic detergents with a variety of precipitants such as sodium dodecylsulfate, sodium tetraphenylboron, ammonium reineckate, potassium dichromate, and potassium hexacyanoferrate(III). A representative titration curve is shown in Fig. 22. However, the absolute emf of the eluctrode drifts rather badly over a period of days, and the slope also decreases, falling to $44 \mathrm{mV} /$ decade after 2 months' use.

A summary of methods for the analysis of surfactants using $\mathrm{ISE}^{\prime} \mathrm{S}$ is given in Table 36.

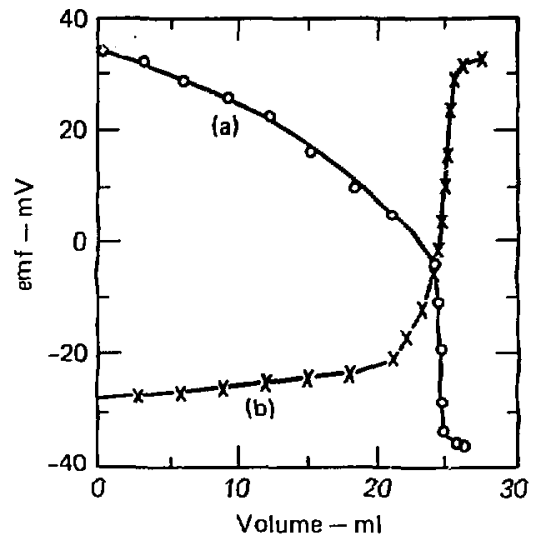

Fig. 22. Potentiometric tit-ations (10-3 $M$ solutions). (a) Titration of $25 \mathrm{~m} 1$ hexadecyltrimethylammonium brimide solution with sodium titraphenylboron solution (e.p. $24.8 \mathrm{m1}$ ). (b) Titration of $25 \mathrm{ml}$ sodium tetraphenylboron solution with hexadecyltrimethylammonium iromide solution (24.7 ml) Source: Ref. 18, used with permission.

\section{References}

1. C. Botré, D. G. Hall, and R. V. Scowen, Kolloid Z. Z. Polym., 250, 900 (1972).

2. K. Shirahama, Kö̈Zoid 2. 2. Polym., 250, $6: 20$ (1972).

3. B. J. Birch and D. E. Clarke, Anatyt. Chim. Acta, 61, 159 (1972).

4. C. Gavach and C. Bertrand, Analyt. Chim. Acta, 55, 385 (1971).

5. C. Gavach and P. Seta, Anazyt. Chim. Acta, 50, 40 ? (1970).

6. I. Guasta1la and C. Gavach, Brevet ANVAR, 690, 1276 (1969).

7. B. J. Birch and D. E. Clarke, Analyt. Chim. Acta, 67, 387 (1973).

B. B. J. Birch and D. E. Clarke, Analyt. Chim. Acta, 69, 473 (1974).

9. B. J. Birch, D. E. Clarke, R. S. Lee, and J. Oakes, Analyt. Chim. Aeta, 70, 417 (1974).

10. N. Ishibashi, H. Kohara, and K. Horinouch1, Tatanta, 20, 867 (1973).

11. T. Fujinaga, S. Okazak1, and H. Freiser, Anal. Chem., 46, 1842 (1974).

12. R. W. Cattrall and H. Freiser, AnaZ. Chem., 43, 1905 (1971). 
13. M. Kataoka and T. Kambara, Bunseki Kagaku, 23, 1081 (1974); cf. Chem. Abstr., 82, 60427x (1975).

14. M. Kataoka and T. Kambara, Denki Kagaku Oyobi Kogyo Buouri Kagaku, 43, 209 (1975); through Chem. Abstr., 83, 195644g (1975).

15. T. Tanaka, K. Hilro, and A. Kawahara, Anal. Letters, 7, 173 (1974).

16. G. Popa, B. Geafar, and C. Luca, Rev. Chim. (Buchorest), 25, 748 (1974); through Chem. Abstr., 83, 12719t (1975).

17. R. A. Llenado, Anaz. Chem., 47, 2243 (1975).

18. A. G. Fogg, A. S. Pathan, and D. T. Burns, Analyt. Chim. Acta, 69, 238 (1974). 


\section{FUNCTIONAL GROUP ANALYSIS}

\section{Divalent Sulfur Functions}

A thorough treatmient of the analysis of divalent sulfur functions in organic compounds is given in the monographs by Karchmer ${ }^{1,2}$ and Siggia. This section deals mainly with the determination of thiols using ISE's, although several other divalent sulfur functions, such as disulfides and thiourea, are also mentioned.

Thiols

Papp and Havas ${ }^{4}$ in 1970 first used In ISE as endpoint detector in the potentiometric titration of thiols. The titrants were 0.02 and $0.05 \mathrm{M}$ mercuric chloride; the ISE was a sulfideselective membrane electrode (Radelkis Type OP-S-711) that behaved reversibly toward mercuric ions. The thiols determined were methy1 mercaptan, potassium thiophenolate, mercaptoethanol, and thiocresol. Watersoluble thiols were determined in $0.1 \mathrm{M}$ sodium hydroxide, whtle waterinsoluble thiols were determined in ethanol. The mercuric chloride titrant was considered more suitable for the determination of thiols than silver nitrate, since the latter may form complexes leading to high results. Kolthoff and Eisenstadter 5 also found mercury mercaptides to be considerably more stable than silver mercaptides. In additional papers, Papp $^{6,7}$ deals with the determination of thiols in the presence of other sulfur-contalning moieties found in alkaline pulping liquors. As above, thiols were precipitated as mercury mercaptides with mercuric chloride. A sulfide ISE was used to monitor the titrations.

Gruen and Harrap ${ }^{8}$ determined some thiols by potentiometric titration with $0.1 M$ silver nitrate. Titrations were monitored with a silver sulfide electrode (0rion 94-16). The thiols determined at $\mathrm{pH} 2.5$ to 9 in an aqueous medium were mercaptoethanol, glutathione, and L-cysteine. These workers noted very little change in enf until the endpoint was almost reached. In the vicinity of the endpoint the electrode response was very slow; up to 2 min were required to establish the equilibrium potentials. Beyond the endpoint the emf rose rapidly because of the excess of silver ions, giving a Nernstian exponential relation between emf and volume of excess silver ion. Points in the immediate vicinity of the endpoint were ignored, and the endpoint was determined as the intersection of the baseline with the curve of potential vs excess stlver fons, as shown in Fig. 23. 


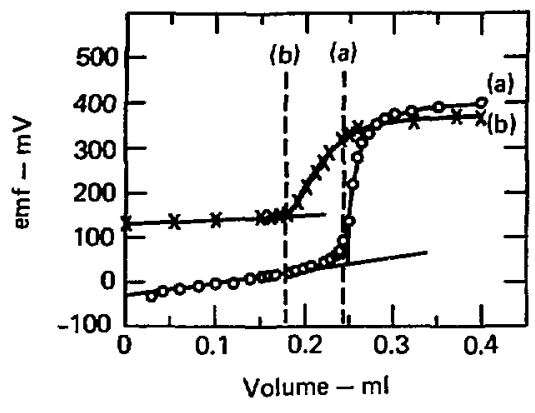

Fig. 23. Addition of (a) $0.1 \mathrm{M} \mathrm{\textrm {ANO } _ { 3 }}$ to $0.2 \mathrm{ml} 0.123 M$ mercaptoethanol in $20 \mathrm{ml} \mathrm{H} \mathrm{H}_{2} \mathrm{O}$; and (b) $1.0 \mathrm{M} \mathrm{AgNO}_{3}$ to $0.2 \mathrm{ml} 0.0888 \mathrm{M}$ glutathlone in $20 \mathrm{ml}$ $\mathrm{H}_{2} \mathrm{O}$. Vertical dashed lines indicate stoichiometric endpoints. Source: Ref. 8, used with permission.

3

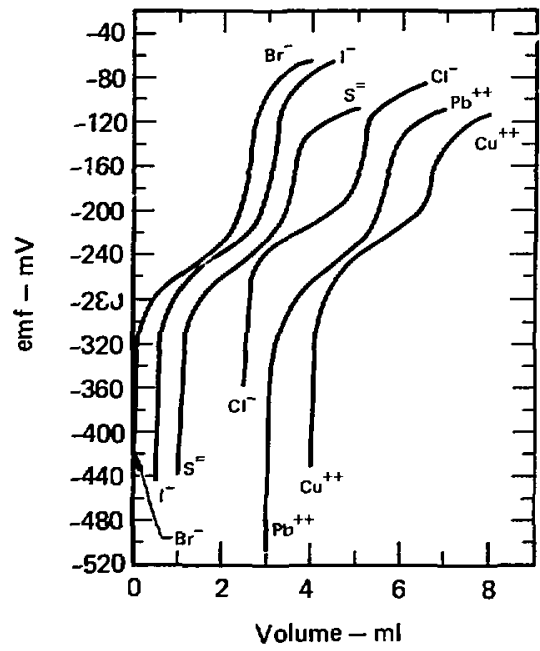

F1g. 24. Titration of approximately $0.03 \mathrm{~mW}$ of 2-mercaptobenzothtazole in acetone; $0.5 \mathrm{ml}$ pyridine added; $0.01 \mathrm{~N}$ mercuric perchlorate. (Curves are displaced horizontally for clarity.) Source: Ref. 9, used with permision.
Selig ${ }^{9}$ has determined a varlety of thiols using ISE's. Microar junts $(0.01$ to $0.1 \mathrm{~m} M)$ were titrated with $0.005 \mathrm{M}$ mercuric perchlorate, while semimicroamounts (0.1 to $0.5 \mathrm{~m} M$ ) were titrated with $0.05 \mathrm{~N}$ titrant. A bromide ISE was used as the Indicator electrode, although other electrodes based on a silver sulfide matr $1 x$ could also be used. Titration curves for approximately $0.03 \mathrm{mM}$ of 2mercaptobenzothiazole in acetone with a varlety of ISE's are shown In Fig. 24. Similar titration curves for the determination of $0.5 \mathrm{mM}$ of dodecanethiol are shown in Fig. 25. In

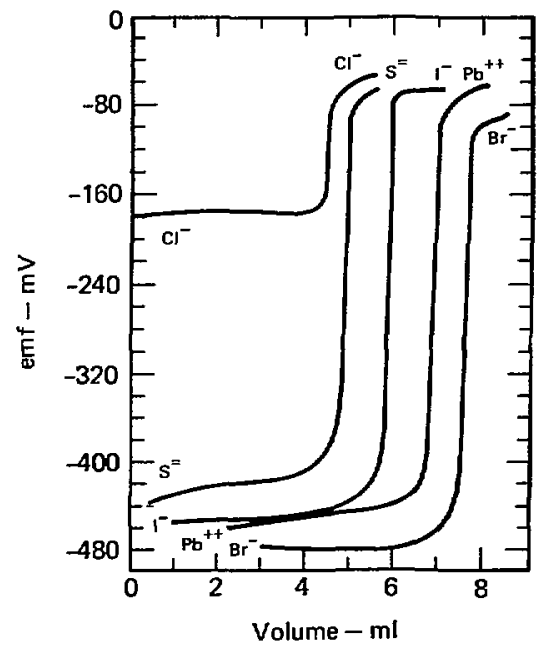

F1g. 25. Titration of approximately $0.5 \mathrm{~m} M$ dodecanethiol in p-dloxane; $1 \mathrm{ml}$ of pyridine and $3 \mathrm{ml}$ of $1 \mathrm{~N}$ $\mathrm{HClO}_{4}$ added; $0.01 \mathrm{~N}$ mercurlc perchlorate. (Curves are displaced horizontally for clarity.) Source: Ref. 9, used with permission. 
general, the electrode response was slower than for other titrations using ISE's, particularly for the more complex thiols and those attached to a heterocyclic ring system.

Acetone was the most universally applicable solvent for thiols, although several (see p. 85) are soluble only in water. Fritz and Palmer ${ }^{10}$ recommended neutralizing the acetonic solution to $\mathrm{pH} 5$ to 7 and buffering with pyridine, since at low pH the carbonyl group may react with the thiol group to form a mercaptal

$$
2 \mathrm{RSH}+\mathrm{C}=\mathrm{O} \longrightarrow \mathrm{C}(\mathrm{RS})_{2}+\mathrm{H}_{2} \mathrm{O} \text {. }
$$

Addition of pyridine also improves the solubility of the mercury mercaptides and enhances the stability of the emf reaaings. Ethanol can also be used as solvent, although the electrode response is usually slower and there is increaged likelihood of precipitation. Since P-Dioxane has more limited applicab111ty, it requires the addition of an electroIyte to increase the dielectric constant of the titration medium; $1 M$ perchloric acid was used for this purpose. In this medium, titrations can be performed at fairly low $\mathrm{pH}$ values.

The assay of a varlety of thiols that can be determined in p-dioxane is shown in Table 37. This table also compares p-dioxane with ethanol and acetone. Table 38 presents the assay of some thiols that either contain additional functional groups or are attached to a heterocyclic ring. These thiols could not be determined

Table 37. Assay of thiols that can be determined in p-dioxane.

\begin{tabular}{|c|c|c|c|c|c|}
\hline Compound & & Acetone & Ethanol & p-dioxane & Remarks \\
\hline \multicolumn{2}{|l|}{ 2-Kercaptopropionfe acld } & $\begin{array}{l}99.63 \\
99.74 \\
99.67\end{array}$ & $\begin{array}{l}99.21 \\
99.21 \\
99.22\end{array}$ & $\begin{array}{l}99.69 \\
99.49\end{array}$ & $\begin{array}{l}\text { Equilibrium in ethanol reached } \\
\text { very slowiy }\end{array}$ \\
\hline & Mean. & 99.68 & 99.21 & 99.59 & \\
\hline \multirow[t]{2}{*}{$\begin{array}{l}\text { 2-Quinolinethiol } \\
\text { (Aldrich) }\end{array}$} & & $\begin{array}{l}81.21 \\
80.94 \\
80.76\end{array}$ & $\begin{array}{l}80.64 \\
80.57\end{array}$ & 81.17 & Precipitate formed in ethanol \\
\hline & Mean & 80.97 & 80.61 & 81.17 & \\
\hline \multirow[t]{2}{*}{$\begin{array}{l}\text { o-Toluenethiol } \\
\text { (Eastman Organfe) }\end{array}$} & & $\begin{array}{l}84.58 \\
84.59 \\
84.57\end{array}$ & 84.89 & $\begin{array}{l}84.82 \\
94.86\end{array}$ & $\begin{array}{l}\text { Precipitate in ethunol cauges } \\
\text { oluggioh response }\end{array}$ \\
\hline & Mean & 84.58 & 84.89 & 84.84 & \\
\hline \multirow[t]{2}{*}{$\begin{array}{l}\text { Thiogalicylic acid } \\
\text { (Evans) }\end{array}$} & & $\begin{array}{l}98.25 \\
98.52\end{array}$ & $\begin{array}{l}97.77 \\
97.82 \\
97.76\end{array}$ & $\begin{array}{l}96.10 \\
96.23 \\
96.22\end{array}$ & $\begin{array}{l}\text { Sluggleh in ethanol and dioxane; } \\
\text { note low resulta in } \mathrm{p} \text {-diome }\end{array}$ \\
\hline & Mean & 98.38 & 97.78 & 96.18 & - \\
\hline
\end{tabular}


Table 37. (Continued)

\begin{tabular}{|c|c|c|c|c|c|}
\hline Cospound & & Acetone & Ethenol & $p$-dLoxane & Retarke \\
\hline \multirow[t]{2}{*}{$\begin{array}{l}\text { Cyclohexy1 mercaptan } \\
\text { (Ph1llips Petroleum) }\end{array}$} & & $\begin{array}{l}88.61 \\
88.36 \\
88.38\end{array}$ & & $\begin{array}{l}88.31 \\
87.96 \\
88.15\end{array}$ & $\begin{array}{l}\text { Poorly defined endpoint bresko } \\
\text { in ethanol }\end{array}$ \\
\hline & Kean & 88.45 & & 88.14 & \\
\hline \multirow[t]{2}{*}{$\begin{array}{l}\text { Tert. hexadecylnercaptan } \\
\text { (Ph1llips Petroleum) }\end{array}$} & & $\begin{array}{l}77.76 \\
77.79\end{array}$ & & $\begin{array}{l}77.43 \\
77.43\end{array}$ & Not determined in ethanol \\
\hline & Mean & 77.78 & & 77.43 & \\
\hline \multirow[t]{2}{*}{$\begin{array}{l}\text { n-Yonylmercaptan } \\
\text { (Aldr1ch) }\end{array}$} & & $\begin{array}{l}97.23 \\
97.22\end{array}$ & & $\begin{array}{l}97.21 \\
97.17\end{array}$ & Not determined in ethanol \\
\hline & Mean & 97.23 & & 97.19 & \\
\hline \multicolumn{2}{|c|}{$\begin{array}{l}\text { Tert. tertradecylmercaptan } \\
\text { (Ph1111ps Petroleum) }\end{array}$} & $\begin{array}{l}98.23 \\
9 E \cdot 34 \\
98.34\end{array}$ & & $\begin{array}{l}98.74 \\
98.69 \\
98.75\end{array}$ & Not determined in ethanol \\
\hline & Mean & 98.30 & & 98.73 & \\
\hline \multirow[t]{2}{*}{$\begin{array}{l}\text { Tert. Jojecylmercaptan } \\
\text { (Phil:ips Petroleum) }\end{array}$} & & & & $\begin{array}{l}98.26 \\
98.34\end{array}$ & \\
\hline & Mean & 98.30 & & 98.73 & \\
\hline \multirow[t]{2}{*}{$\begin{array}{l}\text { Tert. octylmercaptan } \\
\text { (Phill1ps Petroleum) }\end{array}$} & & & & $\begin{array}{l}96.25 \\
96.35 \\
96.35\end{array}$ & \\
\hline & Mean & & & 98.32 & \\
\hline \multirow[t]{2}{*}{$\begin{array}{l}\text { Thtomalic actd } \\
\text { (Evans) }\end{array}$} & & $\begin{array}{l}96.30 \\
96.28\end{array}$ & $\begin{array}{l}96.34 \\
96.20 \\
96.26\end{array}$ & $\begin{array}{l}95.36 \\
95.36 \\
95.82\end{array}$ & $\begin{array}{l}\text { Water } \\
96.03 \\
96.05\end{array}$ \\
\hline & Mean & 96.29 & 96.30 & 95.51 & 96.04 \\
\hline \multirow[t]{2}{*}{$\begin{array}{l}\text { B-d-Thloglucose } \\
\text { cetraacetate } \\
\text { (Aldrfch) }\end{array}$} & & $\begin{array}{l}95.66 \\
95.69\end{array}$ & $\begin{array}{l}96.00 \\
96.00 \\
95.94\end{array}$ & $\begin{array}{l}95.81 \\
95.71\end{array}$ & \\
\hline & Mean & 95.68 & 95.98 & 95.76 & \\
\hline \multirow[t]{2}{*}{$\begin{array}{l}\text { a-Th1o-2-furan-pyruvic } \\
\text { ac1d } \\
\text { (Aldrich) }\end{array}$} & & $\begin{array}{l}89.52 \\
89.43 \\
89.39\end{array}$ & & $\begin{array}{l}89.39 \\
89.28\end{array}$ & $\begin{array}{l}\text { Not feastble in ethanol; } \\
\text { very slaw in dioxane }\end{array}$ \\
\hline & Mean & 89.45 & & 89.34 & \\
\hline \multirow[t]{2}{*}{$\begin{array}{l}\text { 1-DodecanethIol } \\
\text { (Mldrich) }\end{array}$} & & & & $\begin{array}{l}94.88 \\
94.58 \\
94.56 \\
94.88\end{array}$ & \\
\hline & Hean & & & 94.73 & \\
\hline \multirow[t]{2}{*}{ 1,10-Dodecaned1th1ol } & & & & $\begin{array}{l}97.89 \\
97.48\end{array}$ & \\
\hline & Hean & & & 97.69 & \\
\hline p-xylylyl dimercaptan & & & & 97,48 & \\
\hline
\end{tabular}

a Th1s compound ylelded two breaks when titrated wth a base, the firat corresponding to the carboxylic acid, and the second less well-defined break corresponding to the thiol group.

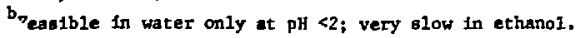


Table 38. Assay of thiols that cannot be determined in p-dioxane.

\begin{tabular}{|c|c|c|c|}
\hline Compound & Acetone & Ethanol & Remarks \\
\hline $\begin{array}{l}\text { Thlonalide }{ }^{a} \\
\text { (Eastman Organic) }\end{array}$ & $\begin{array}{l}87.24 \\
87.27 \\
87.27\end{array}$ & $\begin{array}{l}87.07 \\
87.06\end{array}$ & \\
\hline Mean & 87.26 & 87.07 & \\
\hline $\begin{array}{l}\text { 2-Mercaptobenzothiazole } \\
\text { (MC \& B) }\end{array}$ & $\begin{array}{l}95.74 \\
95.65 \\
95.65\end{array}$ & $\begin{array}{l}95.50 \\
95.55\end{array}$ & Slower in ethanol \\
\hline Mean & 95.68 & 95.53 & \\
\hline $\begin{array}{l}\text { 2-Mercaptopyridine } \\
\text { (MIdrich) }\end{array}$ & $\begin{array}{l}95.98 \\
95.45 \\
95.81 \\
95.46\end{array}$ & $\begin{array}{l}85.77 \\
95.69 \\
95.97\end{array}$ & Precipltate in ethanol \\
\hline Mean & 95.68 & 95.81 & \\
\hline 2-Mercaptobenzoxazole & $\begin{array}{l}97.74 \\
97.94 \\
97.82\end{array}$ & & \\
\hline Mean & 97.87 & & \\
\hline $\begin{array}{l}\text { Mercaptoacetic acid } \\
\text { (Eastman Organic) }\end{array}$ & $\begin{array}{l}74.57 \\
74.57 \\
74.59\end{array}$ & $\begin{array}{l}74.85 \\
74.88 \\
74.91\end{array}$ & $\begin{array}{l}\text { Water } \\
74.45 \\
74.45 \\
74.70\end{array}$ \\
\hline Mean & 74.58 & 74.88 & 74.53 \\
\hline $\begin{array}{l}\text { Bismuththlol II } \\
\text { (A.drich) }\end{array}$ & $\begin{array}{l}94.58 \\
94.42 \\
94.29\end{array}$ & & $\begin{array}{l}\text { Not feasible in ethanol and } \\
\text { water, although soluble }\end{array}$ \\
\hline Mean & 94.43 & & \\
\hline $\begin{array}{l}\text { Diphenyldithiophosphinic } \\
\text { acid (Aldrich) }\end{array}$ & $\begin{array}{l}93.60 \\
93.31 \\
93.55\end{array}$ & & \\
\hline Mean & 93.49 & & \\
\hline
\end{tabular}

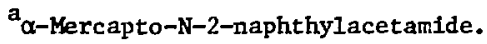

${ }^{b}$ slower In ethanol and water; feasible in water only at $\mathrm{pH}<2$.

5-Mercapto-3-phenyl-1,3,4-thiadiazole-2-thione, potassium salt. 
Table 39. Assay of water-soluble thiols.

\begin{tabular}{|c|c|c|c|}
\hline Compound & & Assay & Remarks \\
\hline \multirow[t]{2}{*}{$\begin{array}{l}\text { Mercaptoacetic acid, } \\
\text { sodium salt } \\
\text { (Aldrich) }\end{array}$} & & $\begin{array}{l}63.75 \\
63.67 \\
63.93\end{array}$ & $\begin{array}{l}\text { Feastble on } 1 \mathrm{y} \text { at } \mathrm{pH}<2 \text {; also } \\
\text { feasible in acetone at } \mathrm{pH}<1\end{array}$ \\
\hline & Mean & 63.78 & \\
\hline \multirow[t]{2}{*}{$\begin{array}{l}\text { 2-Mercaptoethylarine } \\
\text { hydrochloride } \\
\text { (Evans) }\end{array}$} & & $\begin{array}{l}95.28 \\
95.38 \\
95.47 \\
95.27\end{array}$ & $\begin{array}{l}\text { Starting } \mathrm{pH} 5 \text { to } 6 \text { (pyridine } \\
\text { buffer) }\end{array}$ \\
\hline & Mean & 95.35 & \\
\hline \multirow[t]{2}{*}{$\begin{array}{l}\text { Glutathione, reduced } \\
\text { (Aldrich) }\end{array}$} & & $\begin{array}{l}99.19 \\
98.82 \\
99.06\end{array}$ & $\begin{array}{l}\text { Best wlthout additives, but can } \\
\text { be run in dilute perchloric } \\
\text { acid }\end{array}$ \\
\hline & Mean & 99.02 & \\
\hline \multirow[t]{2}{*}{$\begin{array}{l}\text { L-cysteine hydrochloride } \\
\text { hydrateb } \\
\text { (Aldrich) }\end{array}$} & & $\begin{array}{l}99.60 \\
99.35 \\
99.48 \\
99.68\end{array}$ & $\begin{array}{l}\text { Starting pH } 3 \text { to } 8 \text { (pyridine } \\
\text { buffer }\end{array}$ \\
\hline & Mean & 99.53 & \\
\hline \multirow[t]{2}{*}{$\begin{array}{l}\mathrm{L}-(+) \text {-cysteine } \\
\text { (J.T. Baker) }\end{array}$} & & $\begin{array}{l}92.95 \\
93.08 \\
93.01\end{array}$ & Starțing pH 2 to 6 \\
\hline & Mean & 93.01 & \\
\hline
\end{tabular}

${ }^{a_{\gamma}}$-L-glutamy1-L-cysteinylglycine.

$b_{99,5 \%}$ assay by titration with base.

In p-dioxane because of the extremely slow response of the electrode.

Table 39 shows the assay of thiols that were soluble only in water. They consisted of alkali salts of acids, and amine hydrochlorides or more

complex molecules containing amino and acid groups, such as reduced glutathione and cystetne.

No interferences were found from equivalent amounts of disulfides, such as cystine and dibenzyl disulfide, or from organic sulfides, such as 3thiomorpholine, 4-methylmercaptoaniItne, tiiphenylphosphine sulfide, and thiophene. Several thiols attached to heterocyclic rings such as 2mercuptclenzimfdazole, 2-mercaptothiazoline, and 8-mercaptopurlne could 
not be analyzed by the method given. This may posslbly be due to tautomeric effects.

In a study on the release of hydrogen sulfide and methyl mercaptan from L-cystelne, S-methy1-L-cysteine, and DL-methionine, the thtol was absorbed in $1 M$ sodfum hydroxide. 11 It was then titrated with silver nitrate using a silver sulfide ISE as endpoint detector.

Prior to the advent of ISE's, Watts et $a l .^{12}$ have determined the total reactive thiol content of simple thiols and some proteins by measuring the iodide produced after reactions with an excess of iodoacetate:

$$
\begin{array}{r}
\mathrm{RS}^{-}+\mathrm{ICH}_{2} \mathrm{COO}^{-} \\
\mathrm{RSCH}_{2} \mathrm{COO}^{-}+\mathrm{I}^{-}
\end{array}
$$

A specially prepared silver silver iodide electrode was used for direct emf measurement in a constant ionic strength medium. The electrode deteriorated with aging and had to be rejuvenated periodically. Obviously, this study could be simplified considerably by means of an iodide ISE.

Peter and Rosset ${ }^{13}$ reported the potentiometric titration of several thiols in a nonaqueous medium with an Orion 94-16A silver sulfide ISE. The reference electrode was a silver silver chloride electrode in 2:1 ethanol: benzene with an ammonia/amnonium nitrate in 2:1 ethanol:benzene salt bridge. The solvent was a $2: 1 \mathrm{mix}-$ ture of ethanol:benzene, buffered to $\mathrm{pH} 1.0 .8$ with $0.04 \mathrm{M}$ andnonda/ammonium nitrate. The titrant was $0.01 M$ silver nitrate in isopropanol. The responses of ethanethiol, propanethiol, dodecanethiol, benzenethiol, and hydrogen sulfide were studied in ethano1:benzene by direct potentiometry. Only hydrogen sulfide yielded a Nernstian response over the range of $10^{-2}$ to $10^{-5} \mathrm{M}$. The response of ethanethiol was linear with a slope of $84 \mathrm{mV}$; the response of benzenthiol also was linear with a slope of $93 \mathrm{mV}$.

However, the silver sulfide ISE could be used to follow the potentiometric titration of the same thiols as well as of hydrogen sulfide. Mixtures of hydrogen sulfide and thiol yielded potentlometric breaks, as shown in Fig. 26. The first break is due to hydrogen sulfide. However, errors in the amount of thiol are caused by coprecipitation. The shape of the curves depends upon the rate of addition of the titrant.

All titrations were performed under a nitrogen blanket to minimize air oxidation. For a thtol level of about $I m M$, equilibrium was reached about 3 min after each addition, except near the endpoint, where 10 min was required. Since the silver 


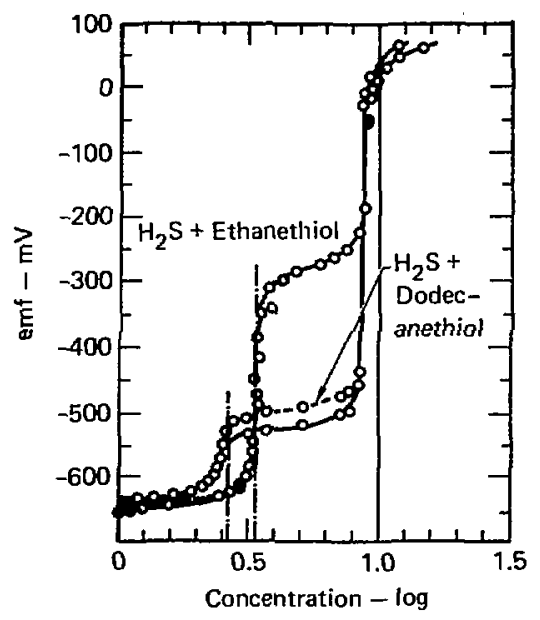

Fig. 26. Titration of mixtures of hydrogen sulfide and thiols with silver ions. Source: Ref. 13, used with permission.

sulfide ISE needs neither pretreatment nor maintenance (unlike the classical silver silver sulfide electrode), this method simplifies the potentiometric titration of thiols.

In a later paper, Peter and Rosset $^{14}$ discuss errors that can affect the accuracy of the titration of hydrogen sulfide and thiols with silver ions. Hydrogen sulfide, methanethiol and ethanethiol are so volatile that titrations should be done in the opposite direction to the classical method: The sulfur compounds to be determined should be used as titrants. Silver hydroxide precipitation can be avoided by operating in a sufficlently actdic medium, at a pH of 1 to 2 .

Tseng and Gutknecht ${ }^{15}$ measured several thiols in aqueous sodium hydroxide solutions by direct potenitometry. A silver sulfide ISE was used, and an SCE reference. The electrode responded 11nearly to sulfide concentrations in the range of $10^{-1}$ to $10^{-6} \mathrm{M}$. The detertion limit for thiols was about $10^{-4} M$. The slopes of emf vs thlol concentration for cysteine, thioglycolic acid, 3mercaptopropionic acid, and 2mercaptoethanol were used to calculate the formulas of the silver-thiol complexes and their apparent formation constants (shown in Table 40). The average slope for the $1: 2$ complexes was $109 \mathrm{mV}$; 1,2-dithioethane and thiophenol did not yield stable potentials. Solution of these thiols showed the presence of a white precipitate upor standing for a period of time, probably the formation of oxidation products. Thioacetic acid yielded a response slope of $28 \mathrm{mV} /$ per decade. It is apparent that this compound is easily hydrolyzed and the Lon detected is the sulfide ion.

Chiu and Paszner ${ }^{16}$ studied the potentiometric titration behavior of sodium sulfide, methyl mercaptan, dimethyl sulfide, dimethyl disulfide, and polysulfides in mixed alkaline solutions and in sulfate pulping black liquors. A silver sulfide ISE 
Table 40. Results of the evaluation of the thtol response curves.

\begin{tabular}{|c|c|c|c|c|c|}
\hline Thiols & $\begin{array}{l}\mathrm{pk}, \\
-\mathrm{sH}\end{array}$ & 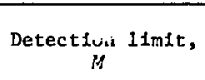 & $\begin{array}{l}\text { Response } \\
\text { slope, } \\
\text { mv/decade }\end{array}$ & 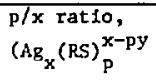 & Possible complex formula \\
\hline Cysteine & 8.33 & $\begin{array}{l}2.0 \times 10^{-4} \mathrm{H} \\
\quad(\mathrm{In} 0.1 M \mathrm{NaOH})\end{array}$ & -108 & $\frac{1.9^{\mathrm{a}}}{(2.0)^{\mathrm{b}}}$ & $\mathrm{Ag}-\mathrm{SCH}_{2} \mathrm{CH}\left(\mathrm{NH}_{2}\right) \mathrm{CO}_{2}^{-}{ }_{2}^{3-}$ \\
\hline $\begin{array}{l}\text { ThLoglycolic } \\
\text { acid }\end{array}$ & 10.67 & $\begin{array}{l}1.0 \times 10^{-4} \mathrm{M} \\
(1 \mathrm{n} 1 \mathrm{~N} \mathrm{NOH})\end{array}$ & -110 & $\begin{array}{l}1.9^{\mathrm{a}} \\
(2.0)^{\mathrm{b}}\end{array}$ & $\mathrm{Ag}\left(\mathrm{SCH}_{2} \mathrm{CO}_{2}^{-}\right)_{2}^{3-}$ \\
\hline $\begin{array}{l}\text { 3-Mercapto- } \\
\text { propiontc ac1d }\end{array}$ & 10.27 & $\begin{array}{l}2.0 \times 10^{-4} \mathrm{H} \\
\quad(\mathrm{In} 5 \mathrm{MaOH})\end{array}$ & -110 & ${ }^{1.9^{\mathrm{a}}}$ & $\mathrm{Ag}\left(-\mathrm{SCH}_{2} \mathrm{CH}_{2} \mathrm{CO}_{2}^{-}\right)_{2}^{3-}$ \\
\hline $\begin{array}{l}\text { 2-Mercapto- } \\
\text { ethanol }\end{array}$ & 9.50 & $\begin{array}{l}1.0 \times 10^{-4} M \\
(\ln 5: ! \mathrm{NaOH})\end{array}$ & -84 & $\begin{array}{l}1.4^{\mathrm{a}} \\
(1.5)^{\mathrm{b}}\end{array}$ & $\mathrm{Ag}_{2}\left(\mathrm{SCH}_{2} \mathrm{CH}_{2} \mathrm{OH}\right)_{3}$ \\
\hline
\end{tabular}

${ }^{a}$ Calculated using the thoretical electrode response to $\left[\mathrm{Ag}^{+}\right], \overline{58 \mathrm{mV} \text { per decade (temperature }}$ adjusted).

${ }^{\mathrm{b}}$ Calculated using the exp $\quad 1$ electrode response to $\left[\mathrm{Hg}^{+}\right], 55 \mathrm{mV}$ per decade.

was used; the titrant was aqueous

silver nitrate. The titration medium was approximately $I M$ sodium hydroxide and contalned $5 \mathrm{ml} 30 \%$ aqueous ammonium hydroxide per $100 \mathrm{ml}$. Up to three inflection points were found: the first due to sulfide, the second due to bound mercaptan (organic/ inorganic oolysulfide), and the third due to free mercaptan.

Table 41. Summary of methods for the determination of thiols using ISE's.

\begin{tabular}{|c|c|c|c|c|}
\hline İSE & Titrant & Medium & Thiols determined & Ref. \\
\hline Silver sulfide & $\begin{array}{l}\text { Mercurtc } \\
\text { chlortde }\end{array}$ & $\begin{array}{l}\text { Ethanol, } \\
0.1 / \mathrm{NaOH}\end{array}$ & $\begin{array}{l}\text { Methy! mercaptan, } \\
\text { potassium thiophenolate, } \\
\text { mercaptoethanol, thiocresol }\end{array}$ & 4 \\
\hline Silver sulfide & Silver nitrate & pH 2.5-9 aqueous & $\begin{array}{l}\text { Mercaptoethanol, } \\
\text { glutathfone, L-cystelne }\end{array}$ & 8 \\
\hline $\begin{array}{l}\text { Bromide and } \\
\text { others based on } \\
\text { silver sulfide } \\
\text { natrix }\end{array}$ & $\begin{array}{l}\text { Mercuric } \\
\text { perchlorate }\end{array}$ & $\begin{array}{l}\text { Acetone or ethanol } \\
\text { plus pyrfdine, water } \\
\text { dioxane }+\mathrm{HClO}_{4}\end{array}$ & W1de variety of thiols & 9 \\
\hline Silver sulfide & $\begin{array}{l}\text { Silver nitrate } \\
\text { in Isopropanol }\end{array}$ & $\begin{array}{l}2: 1 \text { ethanol benzene, } \\
\text { pH } 10.8 \text { buffer }\end{array}$ & $\begin{array}{l}\text { Ethane-, benzene-, } \\
\text { dodecane-, hexane-, } \\
\text { butanethiol }\end{array}$ & 13 \\
\hline Silver sulfide & Direct emf & Sodtum hydroxide & $\begin{array}{l}\text { Cystelne, thicglycolic } \\
\text { acid, 2-mercaptoethanol, } \\
\text { 3-mercaptopropiontc acid }\end{array}$ & 15 \\
\hline Silver Bulfide & Silver nftrate & $\begin{array}{l}\text { Sodium hydroxtde, } \\
\text { ammontum hydroxide }\end{array}$ & Methyl mercaptan & 16 \\
\hline
\end{tabular}




\section{Disuifides}

The determination of disulfides using ISE's was discussed by Papp and Havas $^{4}$ and Harrap and Gruen. 17 The disulfides were reduced to thiols and then determined as such. Papp and Havas $^{4}$ treated a solution containing cystine with excess sodium sulfite at room temperature, at oH 6 to 6.5 for $1 \mathrm{~h}$ according to the reaction

$$
\begin{aligned}
& \mathrm{R}-\mathrm{S}-\mathrm{S}-\mathrm{R}+\mathrm{SO}_{3}^{-} \\
& -\mathrm{R}-\mathrm{S}^{-}+\mathrm{R}-\mathrm{SSO}_{3}^{--}
\end{aligned}
$$

This resulted in quantitative conversion to cysteine which was determined in alkaline solution with mercuric clıloride as described above (p. 80).

Harrap and Gruen ${ }^{17}$ determined disulfide groups in trypsin, ribonuclease, B-lactoglobulin, 1ysozyme, $\alpha$-chymotrypsin, insulin, and serum albumin. The disulfide groups were reduced with sodium borohydride in a two-stage reduction. The maximum number of titratable thiol groups was obtained when the concentration of the borohydride was $0.25 \%$, at a temperature of 40 to $50^{\circ} \mathrm{C}$. Each disulfide group yielded two thiols. The excess reductant was destroyed by addition of acetonic nitric acid. Thiols were titrated with $0.1 M$ silver nitrate using a silver sulfide ISE (as in the determination of thiols ${ }^{8}$ ). Results for all the proteins, with the exception of lysozyme, were within $7 \%$ of 1iterature values obtalned by other methods.

\section{Thiourea}

Thiourea has been determined by Papay et al., 18,19 Pungor et al., 20 and Kucsera-Papay ${ }^{21}$ by direct emf measurements and by potentiometric titrations with silver nitrate. A sulfide-selective membrane electrode (Radelkis Type oP-S-71.1) was used to monitor emf's. As shown in Fig. 27, two breaks appear in the titration curves that are due to the reactions

$$
\text { (1) } \begin{aligned}
& \mathrm{S}=\mathrm{C}_{-\mathrm{NH}_{2}}^{-\mathrm{NH}_{2}}+2 \mathrm{AgNO}_{3} \\
& \mathrm{Ag}_{2} \mathrm{~S}+\mathrm{H}_{2} \mathrm{NCN}+2 \mathrm{HNO}_{3}
\end{aligned}
$$

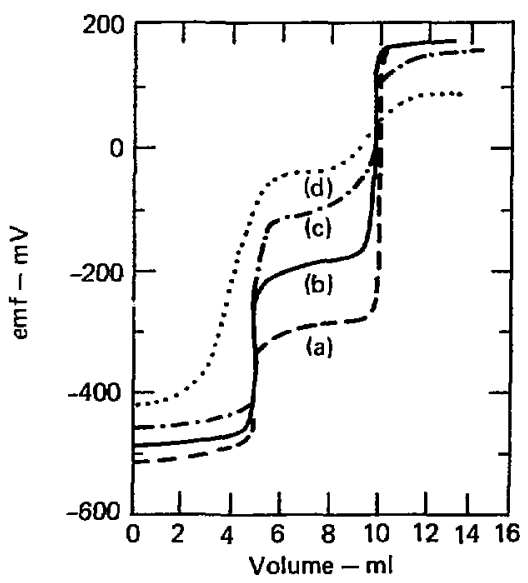

Fig. 27. Potentiometric titration of $10^{-1}$ to $10^{-4} \mathrm{M}$ thiourea solutions with standard silver nitrate solution, in $1 M$ sodium hydroxide. (a) $10^{-1} M$; (b) $10^{-2} \mathrm{M}$; (c) $10^{-3} M$; and (c $10^{-4} M$. Source: Ref, 18, used with permission. 
(2)

$\mathrm{H}_{2} \mathrm{NCN}+2 \mathrm{AgNO}_{3}$

$-\mathrm{Ag}_{2} \mathrm{NCN}+2 \mathrm{HNO}_{3}$.

By direct emf measuremen-, a linear response was obtained over the concent:-ation range of $10^{-1}$ to $10^{-6} \mathrm{M}$ thiourea in the presence of $0.1 \mathrm{M}$ and 1M sodium hydroxide. Potentiometric titrations were successful down to $1 \mathrm{~m} M$ thiourea in $0.1 M$ and $1 M$ sodium hydroxide. Standard mercuric nitrate was also successfully used in the potentiometric titrations. The precipitate obtained in the second reaction has been identified as silver cyanamid by infrared spectrometry and by elemental analysis.

Gordievskii et az. ${ }^{22}$ used a si1ver iodide electrode to determine thiourea by direct potentiometry. The sicpe depends upon the $\mathrm{pH}$ and is maximum in a $0.01 \mathrm{M}$ sulfuric acid medium. In this medium, the response is linear from 10 to $100 \mathrm{~g}$ thiourea/1 (130 to $1300 \mathrm{mb}$ ) with a slope of $120 \mathrm{mV}$. Stable emf readings were reached within 3 min. There was no interference from $\mathrm{Co}, \mathrm{Ni}, \mathrm{Zn}$, Fe(III), amides and carboxylic actds, while iodide, bromide, cyanide and thiocyanate did interfere.

Papay et, al. ${ }^{23}$ determined rheny1thiourea and $\mathrm{N}, \mathrm{N}-\mathrm{d}$ iphenylthiourea in the concentration range of $10^{-1}$ to $10^{-3} M$ by potentiometric titration. A silver sulfide ISE (Radelkis OP-S-711) was used as the indicator electrode; the reference electrode was an SCE with a $0.1 / 4$ potassium nitrate agar salt bridge. The titrant was silver nitrate. The influence of alkali and acid concentration on the course of the reaction was studied. In the presence of nitric acid the two compounds react similarily: Two moles of the organic compound react with $1 k$ silver nitrate, forming a white precipitate and yielding a single potentiometric break.

When phenylthiourea is titrated in the presence of $0.1 \%$ sodium hydroxide silver sulfide is precipitated; the phenylcyanamide formed simultaneously reacts further with silver nitrate to form a silver phenylcyanamide precipitate. The reaction sequence is shown in the following equations:

(1)<smiles>CN1C[Se+](c2ccc(NC(N)=S)cc2)C=CC1=O</smiles>
$\mathrm{Ag}_{2} \mathrm{~S}+\bigcirc-\mathrm{NH}-\mathrm{C} \equiv \mathrm{N}+2 \mathrm{HNO}_{3}$

(O) $\mathrm{NH}-\mathrm{C} \cong \mathrm{N}+\mathrm{AgNO}_{3}$

(2)<smiles>Cc1ccccc1N=[Nb]</smiles><smiles>C=[N+](C=CNC(C)(C)C)c1ccccc1</smiles>

(3) O- $\mathrm{N}=\mathrm{C}-\mathrm{N}=\mathrm{Ag}+\mathrm{HNO}_{3}$ 
Two breaks occur in the titration curve.

When $\mathrm{N}, \mathrm{N}$-diphenylthiourea is titrated with silver nitrate in the presence of $0.1 \mathrm{M}$ sodium hydroxide, silver sulfide is also formed, but no cyanamide-type compound can be formed, owing to the presence of the second phenyl group.

In $1 \mathrm{k}$ sodium hydroxide both compcunds react with two equivalents of silver nitrate to yield silver sulfide and phenylurea or diphenylurea, respectively, according to the following equations:

(1)

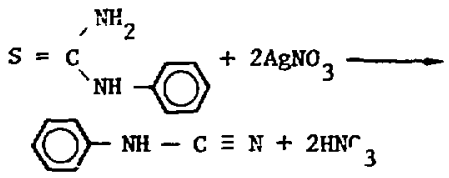

and

(2)

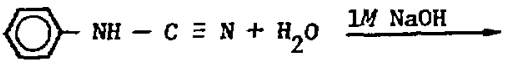<smiles>NC(=O)Nc1ccccc1</smiles>

Presumably, phenyl cyanamide is also formed in the first step, in addition to the silver sulfide precipitate; however, it undergoes hyilolysis in the strongly alkaline medium to form phenylurea or diphenylurea.

\section{Thimcetamide}

Papay et al. ${ }^{20,24}$ also determined thioacetandde in the concentration range of $10^{-1}$ to $10^{-3} \mathrm{M}$ by direct potentionetry and by titration with silver nitrate. The electrode system was the same used for the phenylureas. The effects of acid and alkali concentration on the reaction were studied. In alkaline and slightly acidic $(<0.5 M)$ solution, the reaction product is silver sulfide according to the following equations:

$$
\begin{aligned}
& \mathrm{S}={\underset{\mathrm{NH}}{2}}_{\mathrm{CH}_{3}}^{\mathrm{CH}_{3}}+2 \mathrm{AgNO}_{3}+\mathrm{Ag}_{2} \mathrm{~S}+\mathrm{CH}_{3} \mathrm{CN}+2 \mathrm{HNO} \\
& \mathrm{CH}_{3} \mathrm{CN}+2 \mathrm{H}_{2} \mathrm{O}+\mathrm{CH}_{3} \mathrm{COONH} \\
& 4 \\
& \mathrm{CH}_{3} \mathrm{COONH}_{4}+2 \mathrm{HNO}_{3} \rightarrow \mathrm{CH}_{3} \mathrm{COOH}+\mathrm{NH}_{4} \mathrm{NO}_{3} \\
& +\mathrm{HNO}_{3} .
\end{aligned}
$$

The silver sulfide was identifled by elemental analysis and the ammonium nitrate in the f1ltrate was identifled by its uv spectrum.

When the acid concentration is $>0.5 \mathrm{M}$, a precipitate of silver thioacetamide is formed according to

$$
\begin{aligned}
\mathrm{HS}-\mathrm{C}_{\mathrm{NH}}^{-\mathrm{CH}_{3}}+\mathrm{AgNO}_{3} \\
\\
\rightarrow \mathrm{AgS}-\mathrm{C}_{\mathrm{NH}}^{-\mathrm{CH}_{3}}+\mathrm{HRO}_{3} .
\end{aligned}
$$

If the alkali concentration of the solution is lower than that of the corresponding amount of acid formed during the titration, another potential jump occurs before the endpoint, owing to the decrease of sulfidz concentration governed by hydro.ysis. 


\section{Mercopnopyrimidimone}

Neshkova et al. ${ }^{25}$ determined several mercaptopyrialdines by potentionetric titration with silver nitrate. The electrode system was the same as for 2-mercaptopyrimidines (thiouracils). The concentration range was from $10^{-1}$ to $10^{-3} \mathrm{M}$. The results for three 2-mercaptopyrimidines (thlouracils) are shown in Table 42. These compounds may be regarded as cyclic derivatives of thiourea. The uracils were dissolved in $0.1 M$ sodium hydroxide and adjusted to $\mathrm{pH} 8$ with sodium acetate/acetic acid buffer prior to titration. Silver oxide, which interferes, is is formed in more alkaline soluttons.

Potentfometry and infrared spectra support the following reaction mechanIsm for the case of 2-thfouracil and the quite similar 6-methyl-2thiouractl:<smiles>C=CSc1nccc(Sc2nccc(SCC(C)(C)C)n2)n1</smiles>

$+2 \mathrm{HNO}_{3}$
Tab1e 42, Titration of thlourac11 compounds.

\begin{tabular}{|c|c|c|c|}
\hline Compound & $\begin{array}{l}\text { Taken, } \\
\text { mg }\end{array}$ & $\begin{array}{c}\text { Found, } \\
\text { mg }\end{array}$ & $\begin{array}{c}\text { Recovery, } \\
z\end{array}$ \\
\hline 2-Th1ourac1l & $\begin{array}{r}63.8 \\
25.6 \\
12.8 \\
6.4\end{array}$ & $\begin{array}{r}63.8 \\
26.0 \\
12.8 \\
6.5\end{array}$ & $\begin{array}{l}100.0 \\
101.6 \\
100.0 \\
102.1\end{array}$ \\
\hline $\begin{array}{l}\text { 6-Methy1-2- } \\
\text { thLouracil }\end{array}$ & $\begin{array}{r}28.4 \\
7.1\end{array}$ & $\begin{array}{r}28.6 \\
7.5\end{array}$ & $\begin{array}{l}100.7 \\
105.6\end{array}$ \\
\hline 2,4-Dithiouracil & $\begin{array}{r}36.0 \\
28.8 \\
14.4 \\
7.2\end{array}$ & $\begin{array}{r}35.3 \\
28.5 \\
14.0 \\
7.1\end{array}$ & $\begin{array}{l}98.0 \\
98.9 \\
97.2 \\
98.6\end{array}$ \\
\hline
\end{tabular}

Mean of three determinations.

and the following mechanism for tine titration of 2,4-dithiouractl<smiles>C#C[C@H](C)c1cc(O)nc(S)n1</smiles>

$$
+\mathrm{AgNO}_{3}
$$

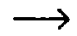<smiles>CSc1nc(C)cc(O)[n+]1[O-]</smiles>

\section{Xanthutes}

Downes ${ }^{26}$ made a preliminary study of the direct determination of xanthate with the orton silver sulfide ISE. Ethyl xanthate gave a IInear 
response above $1 \mathrm{ppm}$. The electrode could also could also be used as the endpoint detector in the potentlometric titration of xanthate with iodine.

Rolla and Ingles ${ }^{27}$ used an Orion silver sulfide ISE tn conjunction with a double-junction rrference electrode In the analysis of flotation mill solutions. In addition to several xanthates, two other sulfur-containing compounds, ammonium diethyldithiophosphate and 2-mercaptobenzothiazole, were analyzed. A Nernstian response was found over the concentration range of $10^{-2}$ to less than $10^{-5} M$ for ethyl xanthate at pH 9.8, amyl xanthate at $\mathrm{pH} 9.6$, diethyldithiophosphate at $\mathrm{pH} 10.0$, and 2-mercaptobenzothiazole at $\mathrm{pH} 11.3$. The $\mathrm{pH}$ adjustments were made with sodium hydroxide solutions.

Potentiometric titrations with silver nitrate proved successful for potassium amyl xanthate and for ammonium diethyldithiophosphate. Mixtures of these two compounds could be differentlated, as shown in Fig. 28 .
The xanthate yielded the first potentlometric break.

\section{Carlen Dimifile}

An unusual application of ISE' $s$ has been the potentionetric determination of carbon disulfide after conversion to sodium wethylxanthate. 28 The latter is monitc ed with a choride ISE in strongly alkaline medium. The analytical concentration range is from 10 to $15 \mathrm{ppm}$; the sensitivity of the method is about $0.02 \mathrm{ppm}$.

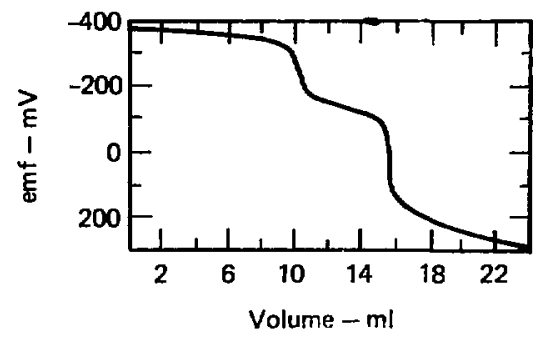

Fig. 28. Titration with $10^{-2} \mathrm{M} \mathrm{AgNO}_{3}$ of a mixed solution of $10^{-2} \mathrm{M}$ potassium amyl xanthate $(10 \mathrm{ml})$ and $10^{-2} M$ ammonium diethyldithiophosphate (5 $\mathrm{ml}$ ) added to $100 \mathrm{ml} \mathrm{H} \mathrm{H}_{2}$. Source: Ref. 27, used with permission.

\section{References}

1. J. H. Karchmer, "Divalent Sulfur-based Functions," in Treatise on Analytical Chemistry, Part II, Vol. 13, I. M. Kolthoff and P. J. Elving, Eds. (Interscience, New York, 1966), p. 337.

2. J. H. Karchmer, Ed., The Analytical Chemistry of Sulfion and Its Compounds (Interscience, New York, 1970).

3. S. S1ggia, Quantitative Organic Analysis Via Funciional Groups, (W1ley and Sons, New York, 1963), 3rd. ed., p. 563. 
4. J. Papp and J. Havas, Proc. 3rd Analyt. Chemistmy Conf., Publishing House of the Hungarian Academy of Sclences, Budapest, 1970, Vol. 2, p. 41.

5. I. M. Kolthoff and J. Eisenstädter, Analyt. Chim. Acta, 24, 83 (1961).

6. J. Papp, CelZuZ. Chem. Technol., 5, 147 (1971); cf. Chem. Abstr., 75, 78333d (1971).

7. J. Papp, Svensk Popperstidn., 74, 310 (1971); cf. Chem. Abstr., 75, $50575 \mathrm{k}$ (1971).

8. L. C. Gruen and B. S. Harrap, Anal. Biochem., 42, 377 (1971).

9. W. Selig, Mikrochim. Acta, 1973, 453.

10. J. S. Fritz and T. A. Palmer, AnaZ. Chem., 33, 98 (1961).

11. D. W. Gruenwede1 and R. K. Patnaik, J. Agr. Food Chem., 19, 775 (1971); through Chem. Abst., 75, 71311m (1971).

12. D. C. Watts, B. R. Rabin, and E. M. Crook, Biochim. Biophys. Acta, 48, 380 (1961).

13. F. Peter and R. Rosset, Analyt. Chim. Acta, 64, 39? (1973).

14. F. Peter and R. Rosset, Analyt. Chim. Acta, 70, 149 (1974).

15. P. K. C. Tseng and W. F. Gutknecht, Anal. Chem., 47, 2316 (1975).

16. S-t Chiu and L. Paszner, Anal. Chem., 47, 1910 (1975).

17. B. S. Harrap and L. C. Gruen, Anal. Biochem., 42, 398 (1971).

18. M. K. Papay, K. Toth, and E. Pungor, Analyt. Chim. Acta, 56, 291 (1971).

19. M. K. Papay, K. Toth, and E. Pungor, Ion-Selec. Electrodes, Symp., 1972, 225; cf.Chem. Abstr., 79, 26917k (1973).

20. E. Pungor, K. Toth, and M. K. Papay, Chem. Anal. (Warsaw), 17, 947 (1972).

21. M. Kucsera-Papay, Kem. Kozl.m., 39, 35 (1973); cf. Chem. Abstr., 79, 73358; (1973).

22. A. V. Gordievskii, 0. A. Zemskaya, N. I. Savvin, V. S. Shterman, and

A. Ya. Syrchenikov, Zh. Anal. Khim., 29, 164 (1974).

23. M. K. Papay, V. P. Izvekov, K. Toth, and E. Pungor, Analyt. Chim. Acta, 69, 173 (174).

24. M. K. Papay, K. Toth, V. Izvekov, and E. Pungor, Analyt. Chim. Acta, 64, 409 (1973).

25. N. T. Neshkova, V. P. Izvekov, M. K. Papay, K. Toth, and E. Pungor, Analyt. Chim. Acta, 75, 439 (1975). 
26. K. W. Downes, Admfn. Report ADM 68-1, Canada Dept. of Energy, Mines and Resources, P. 19 (1968).

27. E. Rolla and J. C. Ingles, Can. Mining J., 92, 94 (1971).

28. R. Swlerczek, Zesz. Nauk Politch̆. Slask., Chem., No. 50, 306, (1970); through Chem. Abstr., 74, 119819s (1971). 


\section{Epoxides}

The determination of epoxy groups was reviewed recently in a monograph by Dobinson et $a l^{1}{ }^{1}$ These authors regard the reaction of epoxides with hydrogen bromide generated in situ (by addition of perchloric acid to a quaternary ammonium halide) as the most promising and important general technique for determining the epoxide group.

A bromide ISE has been recommended $^{2}$ as the endpoint detector in a modification of ASTM method D 1652-67 (standard method of test for epoxy content of epoxy resins). This method is based on the direct hydrobromination of epoxides with hydrobromic acid in glacial acetic acid, a relatively slow reaction. Moreover, the reagent is moisturesensitive and unpleasant to handle; it requires frequent standardization. This procedure has been improved by Selig and Grossman ${ }^{3}$ (see also Ref. 4) by combining the use of a bromide ISE with the generation of hycrobromic acid in situ. The excess halide was back-titrated with standard mercuric perchlorate. A comparison of the epoxide content of some resins obtained by this method with the content obtained the perchlorfc acid-tetraethylammonium bromide method ${ }^{5}$ is shown in Table 43. In general, the new method yielded epoxide contents lower by 2 to $3.4 \%$. The main objective of Selig's work, however, was the estimation of the curing rate of epichlorohydrin/ bisphenol A type epoxy resins cured with complex amines or polyamides. Since the method is based on a comparison of the epoxide content of the cured resin with that of the uncured input material, possible errors in epoxide content tend to cancel out.

Table 43. Determination of epichlorohydrin/bisphenol a type epoxy resins.

\begin{tabular}{|c|c|c|c|c|}
\hline \multirow[b]{2}{*}{ Materlal ${ }^{a}$} & & \multicolumn{2}{|c|}{$\begin{array}{c}\text { Mercuric perchlorate } \\
\text { titration }\end{array}$} & \multirow{2}{*}{$\begin{array}{l}\mathrm{HClO}_{4} \\
\mathrm{Et}_{4} \mathrm{NBr} \\
\text { method [5] } \\
\text { equivalent }\end{array}$} \\
\hline & & $\begin{array}{r}\text { Epoxide } \\
\text { mequiv/g }\end{array}$ & $\begin{array}{c}\text { Epoxy } \\
\text { equivaient }\end{array}$ & \\
\hline \multirow[t]{2}{*}{ Epon 828 } & & $\begin{array}{l}5.2549 \\
5.2329 \\
5.2743 \\
5.2687\end{array}$ & $\begin{array}{l}190.3 \\
191.1 \\
189.6 \\
189.8\end{array}$ & $\begin{array}{l}185.9 \\
185.0 \\
135.0\end{array}$ \\
\hline & Mean & 5.2577 & 190.2 & 185.3 \\
\hline \multirow[t]{2}{*}{ Epon 826} & & $\begin{array}{l}5.3998 \\
5.4468 \\
5.3714 \\
5.4099\end{array}$ & $\begin{array}{l}185.2 \\
183.6 \\
186.2 \\
184.8\end{array}$ & $\begin{array}{l}178.5 \\
179.4 \\
179.4 \\
179.2\end{array}$ \\
\hline & Mean & 5.4070 & 185.0 & 179.0 \\
\hline \multirow[t]{2}{*}{ DER 332} & & $\begin{array}{l}5.6465 \\
5.6370 \\
5.6180 \\
5.6526 \\
5.6593\end{array}$ & $\begin{array}{l}177.1 \\
177.4 \\
178.0 \\
176.9 \\
176.7\end{array}$ & $\begin{array}{l}172.6 \\
174.6 \\
174.6\end{array}$ \\
\hline & Mean & 5.6427 & 177.2 & 173.9 \\
\hline \multirow[t]{2}{*}{ Araldite } & & $\begin{array}{l}5.1531 \\
5.1612 \\
5.1762 \\
5.1416 \\
5.1373\end{array}$ & $\begin{array}{l}194.1 \\
193.8 \\
193.2 \\
194.5 \\
194.7\end{array}$ & $\begin{array}{l}189.8 \\
198.1 \\
190.8\end{array}$ \\
\hline & Mean & 5.1539 & 194.1 & 189.9 \\
\hline
\end{tabular}

${ }^{a}$ Epon 828 and 826 are products of Shell Chemical Co. DER 332 is a product of Dow Chemical co. Araldite 6005 is a product of ctba Chentcal Co. 
The cured resing were ground In a water-cooled micromill, suspended In p-dioxane, and reacted with hydrobromic acid generated in situ for 30 min. The excess halide was then back-titrated with mercuric perchlorate using a bromlde ISE as for the uncured resing.

Estimates of curing rates for vartous epoxy systems cured with amines and polyamides at ambient temperature are shown In Table 44. The range of triplicate analyses varled from 0.3 to $1.9 \%$ with an average range of $0.9 \%$. Results agreed well with infrared studies based on the disappearance of the oxirane absorption band at $10.95 \mathrm{\mu m}$.

For the same type of epoxy resin cured with thlol-terminated longchain aliphatic polymers containing disulfide linkages, a modification of the above procedure was required. 6 The titrant, mercuric perchlorate, reacts with thiol as follows ${ }^{7}$ :

$$
\mathrm{Hg}^{++}+2 \mathrm{RSH} \longrightarrow(\mathrm{RS})_{2} \mathrm{Hg}+2 \mathrm{H}^{+} .
$$

This reaction, however, can be used for the assay of the thiol-terminated curing agent described on page $u l$. For the determination of epoxide and thiol-terminated curing-agent, a sequential titration with mercuric perchlorate was attempted. The thfol was titrated first, a known excess of tetraethylammontum bromide $\left(\mathrm{Et}_{4} \mathrm{NBr}\right)$ solution was added for reaction with the epoxide, and the excess $\mathrm{Et}_{4} \mathrm{NBr}$ was then back-tftrated. Two we11defined potentiometrlc breaks were obtalned; however, approximately 65\% of the epoxide was found to have reacted with the curing agent during the titration.

Addition of an excess of $\mathrm{Et}_{4} \mathrm{NBr}$ to the components prior to the titration yielded only onc potentlometric break, edrivalent to (requiv thiol + mequiv $\mathrm{Et}_{4} \mathrm{Br}$ added) - (mequiv mercuric perchlorate). In this case, only about $10 \%$ of the epoxide had reacted, showing that the addition of $\mathrm{Et}_{4} \mathrm{NBr}$ stopped the curing reactIon. To estimate the epoxide and the thiol-terminated curing agent, two titrations are therefore required :

- Thio1-terminated curing agent by titration with mercuric perchlorate. Curing agent plus epoxide by ittration with mercurjc perchlorate after addition of excess $\mathrm{Et}_{4} \mathrm{NBr}$.

The degree of cure is calculated from the expression:

$\%$ cure $=[1-$ (mequiv epoxide found) $]$ (mequiv epoxide in unreacted epoxide) ] $\times(100)$. 
Table 44. Estimation of free epoxide and curing rate of reains.

\begin{tabular}{|c|c|c|c|c|}
\hline Sample & $\begin{array}{l}\text { Cure } \\
\text { time }\end{array}$ & & $\begin{array}{l}\text { Epoxide, } \\
\text { mequiv/s }\end{array}$ & $\underset{z}{\text { Cure, }}$ \\
\hline \multirow[t]{2}{*}{$\begin{array}{l}\text { Epon } 826(50 \mathrm{x}) / \\
\text { Versdmid } 140(50 \mathrm{x})\end{array}$} & 17 wk & & $\begin{array}{l}0.2404 \\
0.2350 \\
0.2484\end{array}$ & $\begin{array}{l}95.6 \\
95.7 \\
95.4\end{array}$ \\
\hline & & Mean & 0.2413 & 95.6 \\
\hline \multirow{2}{*}{$\begin{array}{l}\text { Epon } 826(55.2 z) / \\
\text { Versamid } 140(37.0 z) / \\
\text { Merginamide } 2-425(7.87)\end{array}$} & 22 wk & & $\begin{array}{l}0.2232 \\
0.2217\end{array}$ & $\begin{array}{l}95.9 \\
95.9\end{array}$ \\
\hline & & Mean & 0.2225 & 95.9 \\
\hline \multirow[t]{2}{*}{$\begin{array}{l}\text { Araldite } 6005(69.8 \%) / \\
\text { Merglnamide } L-425(29.8 \%) / \\
\text { diethylamino propylamine }(0.4 \%)\end{array}$} & 22 wh & & $\begin{array}{l}0.4723 \\
0.5738 \\
0.5720\end{array}$ & $\begin{array}{l}90.8 \\
88.9 \\
88.9\end{array}$ \\
\hline & & Mean & 0.5394 & 89.5 \\
\hline \multirow[t]{2}{*}{$\begin{array}{l}\text { Epon } 828(65.9 \%) \text { /adduct } \\
\text { of } 12 \% \text { acrylonitrile and } \\
87.1 \% \text { Merginamide L- } 425(34.1 \%)\end{array}$} & 17 wk & & $\begin{array}{l}1.3555 \\
1.3496 \\
1.3464\end{array}$ & $\begin{array}{l}74.2 \\
74.3 \\
74.4\end{array}$ \\
\hline & & Mean & 1.3505 & 74.3 \\
\hline \multirow[t]{2}{*}{$\begin{array}{l}\text { Epon } 828(66.7 \%) / \text { adduct } \\
\text { of } 10 \% \text { arcylonitrile and } \\
90 \% \text { Merginamide L-425 (33.3\%) }\end{array}$} & 22 wk & & $\begin{array}{l}1.5915 \\
1.5291 \\
1.5261\end{array}$ & $\begin{array}{l}69.7 \\
70.9 \\
71.0\end{array}$ \\
\hline & & Mean & 1.5489 & 70.5 \\
\hline \multirow[t]{2}{*}{$\begin{array}{l}\text { Epon } 828(67.4 \%) / \text { adduct } \\
\text { of } 6.9 \% \text { acrylonitrile and } \\
93.1 \% \text { Merginamide L- } 425 \quad(32.6 \%)\end{array}$} & $17 \mathrm{wk}$ & & $\begin{array}{l}1.3771 \\
1.4408 \\
1.4235\end{array}$ & $\begin{array}{l}73.8 \\
72.6 \\
73.1\end{array}$ \\
\hline & & Mean & 1.4138 & 73.1 \\
\hline \multirow[t]{2}{*}{$\begin{array}{l}\text { DER } 322(73.3 \%) / \\
\text { Epi-Cure } 855(26.7 \%)\end{array}$} & $23 d$ & & $\begin{array}{l}1.8395 \\
1.8582 \\
1.8456\end{array}$ & $\begin{array}{l}67.4 \\
67.1 \\
67.3\end{array}$ \\
\hline & & Mean & 1.8478 & 67.3 \\
\hline \multirow[t]{3}{*}{$\begin{array}{l}\text { DER } 332(73.2 \%) / \\
\text { Epi-Gure } 855(26.8 \%)\end{array}$} & $2 \mathrm{~d}$ & & $\begin{array}{l}2.6159 \\
2.5812 \\
2.6347 \\
2.5964\end{array}$ & $\begin{array}{l}53.6 \\
54.3 \\
53.3 \\
54.0\end{array}$ \\
\hline & $32 \mathrm{~d}$ & Mean & $\begin{array}{l}2.6071 \\
1.6809 \\
1.6926 \\
1.6564\end{array}$ & $\begin{array}{l}53.8^{\mathrm{b}} \\
69.5 \\
69.3 \\
70.0\end{array}$ \\
\hline & & Mean & 1.6766 & $69.6^{c}$ \\
\hline
\end{tabular}

\footnotetext{
Formulations as follows: Epon 826, 828: epichlorohydrin/bisphenol A type epoxy resin, She11 Chemical Co. - Versamid 140: Complex aliphatic amido-anine curfing agent, General Mills Corp. (amine value 370). - Merginamide L-425: polyamide curing agent, Stepan Chemical Co. (amine value 402). - Araldite 6005: epichlorohydrin/bisphenol bispheno: A type epoxy resin, CIBA Chemical Co. - DER 332: A type epoxy resin, Dow Chemical Co. - Ept-Cure 855: complex aliphatic amido-amine curing agent, Celanese Corp. (amine value 420).

$\mathrm{b}_{54 \%}$ cure by infrared analysis.

$c_{70} \pm 4 \%$ cure by infrared analysis.
} 


\section{References}

1. B. Dobinson, W. Hofmann, and B. P. Stark, "The Determination of Epoxlde Groups", In Monographs in Organic Functional Group Analysis, Vol. 1,

R. Belcher and W. Anderson, Eds. (Pergamon, New York, 1969).

2. Orion Research, Inc., Application BulZetin No. 10, Cambridge, Mass.

3. W. Selig and G. L. Crossman, 2. analyt. Chem., 253, 279 (1971).

4. W. Sellg, Z, analyt. Chem., 255, 130 (1971).

5. R. R. Jay, Anal. Chem., 36, 667 (1964).

6. Analytical ChemIstry Quarterly Report, 3rd Quarter, 1970, Lawrence LIvermore Laboratory, LIvermore, Calif., Rept. UCID-15644-70-3 (1970), p. 7.

7. J. S. Fritz and T. A. Palmer, Anaz. Chem., 33, 98 (1961). 


\section{Hydroxyl Groups}

\section{Hydroxyl in Polyners}

A specialized appilcation of ISE's Is the titrimetric finish of the determination of hydruxyl groups in polymers. Phosgene has been used for this determination by Bush et al. ${ }^{1}$ The hydroxyl-containing material was reacted with an excess of phosgene in a suitable solvent to form the chloroformate (reaction 1). After removal of the excess reagent, the chloroformate was hydrolyzed and the chloride content of the hydrolyzate, which is equivalent to the original hydroxyl content, was determined by titration with silver nitrate. Selig ${ }^{2}$ has modified the original procedure, applied it on the microscale, and simplified the hydrolysis and titration steps: the chloroformate was reacted with an excess of m-chloroaniline (reaction 2), yielding an equivalent amount of $\mathrm{m}$ chloroaniline hydrochloride. The latter was titrated with standard silver nitrate (reaction 3), using a chloride ISE to monitor the titrati.m In a partially nonaqueous medi11m.

(1) $\mathrm{ROH}+\mathrm{COCl}_{2}+\stackrel{\circ}{\prime \prime} \mathrm{ROCl}+\mathrm{HCl}$

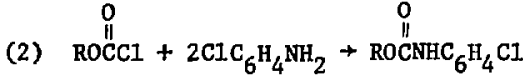

$+\mathrm{ClC}_{6} \mathrm{H}_{4} \mathrm{NH}_{2} \cdot \mathrm{HCl}$
(3) $\mathrm{ClC}_{6} \mathrm{H}_{4} \mathrm{NH}_{2} \cdot \mathrm{HCl}+\mathrm{AgNO}_{3}+\mathrm{AgCl}$

$+\mathrm{ClC}_{6} \mathrm{H}_{4} \mathrm{NH}_{2} \cdot \mathrm{HNO}_{3}$.

This method has been applied to the determination of hydroxyl groups in polyesters, poly (ethylene oxides), and $\alpha$-epoxides. Advantages of the method are that water does not interfere and that, in contrast to all acetylation procedures, it is direct and thus capable of greater accuracy and precision. Limitations of the method are the requirements that the chloroformate formed must be sufficiently stable to withstand the application of vacuum (necessary to remove traces of phosgene and hydrogen chloride) and that samples must be soluble in a suitable aprotic solvent.

Similar modifications may be made in other analytical procedures where the final step consists of the titration of ionic halide.

\section{Vicinal Glycola}

Efstathiou and hadjlloannou ${ }^{3}$ described an automatic potentiometric reaction rate method for the determination of ethylene-, propylene-, and butylene glycol. The vicinal glycols were oxidized with perfodate, and the reaction rate was followed with an Orion 92-81 perchlorate ISE. This electrode exhibits Nernstian behavior at concentrat ns of $10^{-1}$ to $10^{-5} \mathrm{M}$ in the $\mathrm{pH}$ range between 4 and 6 . The 
time required for the reaction to consume a fixed amount of perfodate, and therefore for the emf to Increase by a preselected amount (25 $\mathrm{mV})$, was measured automatically and related directly to the vicinal glycol concentration. The three glycols in the range of $1.4 \times 10^{-3}$ to $7.0 \times 10^{-3} \mathrm{M}$ in a total volume of $28 \mathrm{ml}$ were determined with relative errors of about 0.7\%. Measurement times were only 15 to 150 s. A direct potentlometric method for the determination of ethylene glycol was also described. Ethylene glycol was reacted with a known excess of periodate. The unreacted periodate was then determined with a perchlorate ISE and the amount of ethylene glycol was calculated from the amount of periodate consumed. The relative error for the determination of 6 to $9 \mathrm{mg}$ ethylene glycol was about $0.3 \%$.

\section{Carbohydrates}

Honda et $a I .{ }^{4}$ determined the periodate consumption of several carbohydrates by direct potentiometry. An iodide ISE (Toa Denpa I-125) and a double-junction reference electrode were used to monitor emf's. The basis of this determination is the redox reaction between perfodate and Iodide

$$
\mathrm{IO}_{4}^{-}+2 \mathrm{I}^{-}+\mathrm{H}_{2} \mathrm{O} \longrightarrow \mathrm{IO}_{3}^{-}+\mathrm{I}_{2}+2 \mathrm{OH}^{-} .
$$

The carbohydrates determined were D-sorbitol, D-glucose, D-glucosamtne hydrochloride, D-glucurontc actd, D-glucuronic acid $\alpha$-lactone, and

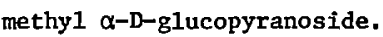

Samples contained 0.01 to $0.5 \mathrm{~m} U$ of carbohydrate. A $10 \%$ excess of $1 \times 10^{-3} M$ potasstum iodide in $0,1 M$ acetate buffer ( $\mathrm{pH} 5$ to 6) was added to the sample solutions containing 0.5 to $2.5 \times 10^{-3} M$ of periodate in the same buffer. After $5 \mathrm{~min}$, the mixtures were extracted with carbon tetrachloride and the concentration of Iodide was determined with the lodide ISE. The amount of periodate consumed was calculated from this. The results from this indirect potentiometric method agree well with those obtained by uv spectrophotometry. A consumption of 4.7 to 5.1 mole of periodate was found per mole of carbohydrate. Only methyl $\alpha-D-$ glucopyranoside showed a lower consumption, of $0.76 \mathrm{M}$ mole periodate pej: mole.

Abou E1-Kheir and Ahmad ${ }^{5}$ described a potentiometric titration for reducing sugars such as glucose. The glucose was heated with $0.1 \mathrm{M}$ mercuric chloride-EDTA disodium salt solution. The unconsumed mercuric Ion was determined without filtration by adding an excess of $0.1 M$ alkaline sodium sulfide solution and back-titrating the excess sulfide ton with $0.1 M$ mercuric chloride-EDTA solution. The 
endpoints were monitored potentiometrically by a sulfide ISE (Radelkis OP-S-712C) and an SCE reference electrode. Between 12 and 42 mg of glucose were determined with an average error of $\pm 1-2 \%$.

\section{Formakichyde}

Tkeda ${ }^{6}$ has used an Orion todtde ISE (94-53) and an SCE in the determination of formaldehyde. The sample was treaced with todine-fodicie solutfon, and the excess iodide was titrrted potentiometrically with silver tons:

$$
\begin{gathered}
\mathrm{HCHO}+\mathrm{I}_{2}+2 \mathrm{KOH} \\
+2 \mathrm{KI}+\mathrm{HCOOH}+\mathrm{H}_{2} \mathrm{O} \\
\mathrm{KI}+\mathrm{AgNO}_{3}+\mathrm{AgI}+\mathrm{KNO}_{3} \\
\mathrm{HCHO} \equiv 2 \mathrm{KI} \equiv 2 \mathrm{AgNO}_{3}
\end{gathered}
$$

according to the sequence of reactions given above. Some results are presented in Table 45. Formic acid and methanol in equinolar amounts to the formaldehyde did not interfere, even ten times that amount gave rise to a positive error of less than $1 \%$. Since acetone and acetaldehyde react with todine, however, they interfere strongly .

\section{Primary Amino Groups}

Hassan ${ }^{7}$ has determfned some primary aromatic amines by forming their hydrochloride salts in ether with gaseous hydrogen chloride. An Orion chloride Is (94-17A) and a doublejunction reference electrode were used to measure emf's directly or to monicor the potentiometric titration vith silver nitrate. Some results are shown in Table 46. The method cannot be applied in the presence of alkalf metal or ammonium salts of carboxylic and sulfonic acids, or when the amino compounds are insoluble in ether.

\section{Carboxylic Acids in the Presence of Acyl Chlorides}

A similar sequence of reactions to that used for the determination of hydroxyl groups in polymers has been employed in a procedure for the semimicrodetermination of carboxylic

\begin{tabular}{|c|c|c|c|c|c|c|}
\hline \multirow{2}{*}{\multicolumn{2}{|c|}{\begin{tabular}{lll} 
& \multicolumn{3}{c}{ Concentration, $M$} \\
$\mathrm{HCHO}, 10 \mathrm{ml}$ & $\mathrm{I}_{2}-\mathrm{KI}, 10 \mathrm{ml}$
\end{tabular}}} & \multirow[b]{2}{*}{$\mathrm{AgNO}_{3}$} & \multicolumn{2}{|c|}{$\mathrm{HCHO}$} & \multirow[b]{2}{*}{$\begin{array}{l}\text { Rel. } \\
\text { error, \% }\end{array}$} & \multirow{2}{*}{$\begin{array}{l}\text { Rel. std } \\
\text { dev, } \\
\%\end{array}$} \\
\hline & & & $\begin{array}{c}\text { Taken, } \\
\text { Ing }\end{array}$ & $\begin{array}{c}\text { Found, } \\
\text { mg }\end{array}$ & & \\
\hline 0.05 & 0.1 & 0.2 & 15.76 & 15.75 & -0.06 & 0.1 \\
\hline 0.005 & 0.01 & 0.2 & 1.576 & 1.577 & +0.06 & 0.2 \\
\hline 0.0005 & 0.001 & 0.01 & 0.158 & 0.170 & +7.6 & 0.4 \\
\hline
\end{tabular}
acids in the presence of a large excess of acyl chloride ${ }^{8}$ :

Table 45. Determination of formaldehyde in dilute solutions. 
Table 46. Potentiometric microdetermination of the primary amino group in some organic compounds.

\begin{tabular}{|c|c|c|c|}
\hline Conpound & $\begin{array}{c}\text { Amino group } \\
\text { Theory, } \\
\%\end{array}$ & $\frac{\text { content }}{\text { Found }}$ & $\begin{array}{c}\text { Recovery, } \\
7\end{array}$ \\
\hline p-Aninobenzoic acid & 11.68 & $\begin{array}{l}11.8 \\
11.9\end{array}$ & $\begin{array}{l}101.0 \\
101.9\end{array}$ \\
\hline p-Aninoacetophenone & 11.85 & $\begin{array}{l}11.7 \\
11.7\end{array}$ & $\begin{array}{l}98 .- \\
98 .\end{array}$ \\
\hline p-Aminobenzene & 8.12 & $\begin{array}{l}8.0 \\
8.2\end{array}$ & $\begin{array}{r}98.5 \\
101.0\end{array}$ \\
\hline p-Arinoplienol & 14.68 & $\begin{array}{l}14.4 \\
14.5\end{array}$ & $\begin{array}{l}98.1 \\
98.8\end{array}$ \\
\hline o-Aminophenol & 14.68 & $\begin{array}{l}14.7 \\
14.5\end{array}$ & $\begin{array}{r}100.1 \\
98.8\end{array}$ \\
\hline Anthranilic acid & 11.68 & $\begin{array}{l}11.7 \\
11.7\end{array}$ & $\begin{array}{l}100.2 \\
100.2\end{array}$ \\
\hline p-Chloraniline & 12.55 & $\begin{array}{l}12.5 \\
12.3\end{array}$ & $\begin{array}{l}99.6 \\
98.0\end{array}$ \\
\hline a-Naphthylamine & 11.19 & $\begin{array}{l}11.5 \\
11.2\end{array}$ & $\begin{array}{l}102.9 \\
100.1\end{array}$ \\
\hline m-Nitroanfline & 11.59 & $\begin{array}{l}11.6 \\
11.5\end{array}$ & $\begin{array}{r}100.1 \\
59.2\end{array}$ \\
\hline EenzIdine & 17.39 & $\begin{array}{l}16.9 \\
17.1\end{array}$ & $\begin{array}{l}97.2 \\
98.3\end{array}$ \\
\hline o-Penylenediamine & 29.63 & $\begin{array}{l}29.3 \\
29.3\end{array}$ & $\begin{array}{l}98.9 \\
98.9\end{array}$ \\
\hline
\end{tabular}

(1) $\mathrm{RCOC1}+2 \mathrm{ClC}_{6} \mathrm{H}_{4} \mathrm{NH}_{2}-$ $\mathrm{RCONHC}_{6} \mathrm{H}_{4} \mathrm{Cl}+\mathrm{ClC}_{6} \mathrm{H}_{4} \mathrm{NH}_{2} \cdot \mathrm{HCl}$

(2) $\mathrm{ClC}_{6} \mathrm{H}_{4} \mathrm{NH}_{2} \cdot \mathrm{HCl}+\mathrm{AgNO}_{3} \longrightarrow$ $\underline{\mathrm{AgCl}}+\mathrm{ClC}_{6} \mathrm{H}_{4} \mathrm{NH}_{2} \cdot \mathrm{HNO}_{3}$

(3) $\mathrm{ClC}_{6} \mathrm{H}_{4} \mathrm{NH}_{2} \cdot \mathrm{HNO}_{3}+\mathrm{RCOOH}+2 \mathrm{NaOH}$ $\longrightarrow \mathrm{NaNO}_{3}+\mathrm{RCOONa}+\mathrm{ClC}_{6} \mathrm{H}_{4} \mathrm{NH}_{2}$

$$
+2 \mathrm{H}_{2} \mathrm{O}
$$

The acyl chloride was reacted with m-chloroaniline (reaction 1) accordIng to Stah1 and Siggia." The m- chloroaniline hydrochloride and the carboxylic acid were then sequentially titrated with sodium hydroxide. A medium of 80 to $90 \%$ p-dioxane was used to enhance the potentiometric breaks.

An alternate approach after conversion of the acyl, chloride with m-chloroaniline (reaction 1) was the titration of the resulting amine hydrochloride with standard silver nitrace according to reaction 2. The reaction was monizored with a silver sulfide IEE. A medium consisting of $80 \%$ acetone was used to enhance the endpoint breaks.

After this, the mixture containing the acid and the amine nitrate salt was titrated with standard sodium hydroxide according to reaction 3 . The carboxylic acid was calculated by difference.

\section{Cyanamide}

The determination of thiourea using a silver sulfide ISE has already been described in the section on thiols and other divalent sulfur functions. ${ }^{10-13}$ In the tiration curve of thiourea with silver nitrate, two jumps appear, the first one being due to the formation of silver sulfide and cyanamide. Therefore, cyanamide can also be titrated potentiometrically with silver nitrate according to the reaction

$$
\mathrm{H}_{2} \mathrm{NCN}+2 \mathrm{AgNO}_{3} \longrightarrow \mathrm{Ag}_{2} \mathrm{NCN}+2 \mathrm{HNO}_{3} .
$$


Titrations were carrfed out in $1 /$ sodium hydroxide. Mixtures of thiourea and cyanamide could be rasolved.

\section{p-Uraxime}

p-Urazine is used as a starting material. for the synthesis of thermostable restns; it also has biological. activity. Kucsera-Papay ${ }^{1.3}$ and Izvekov et al. ${ }^{14}$ have determined it by titration with sliver nitrate in $3 M$ sodium hydroxide. A silver sulfIde ISE (Rade1kis OP-S-711-C) and a saturated calomel reference electrode were used to monitor enf's. During the titration, a black precipitate was formed that proved to be approximately $97 \%$ silver. This suggested that a redox proceeded during the titration which was assumed to be

$$
\begin{aligned}
& \mathrm{O}=\mathrm{C} \underset{\mathrm{H}}{-\mathrm{N}}-\underset{\mathrm{H}}{\mathrm{H}}-\mathrm{N}^{-\mathrm{N}}-\mathrm{C}=\mathrm{O}+4 \mathrm{Ag}^{+} \\
& \longrightarrow \mathrm{O}^{2} \mathrm{C}_{\mathrm{N}=\mathrm{N}}^{-\mathrm{N}=\mathrm{N}}, \mathrm{C}=0+4 \underline{\mathrm{Ag}}+4 \mathrm{H}^{+} .
\end{aligned}
$$

Spectroscopic results on some of the isolated products were in accordance with the potentfometric results and support the postulated reaction. The eruivalent weight of p-urazine was one quarter of the molecular weight. The lower limit of the potentiometric determination was $1 \mathrm{~m} M$.

\section{Refereaces}

1. D. G. Bush, L. J. Kunzelsauer, and S. H. Merril1, AnaZ. Chem., 35, 1250 (1963).

2. W. Selig, Mikrochim. Acta, 1972, 612 .

3. C. H. Efstathlou and T. P. Hadjiioannou, Anal. Chem., 47, 864 (1975).

4. S. Honda, K. Sudo, K. Kakehi, and K. Takiura, Analyt Chim. Acta, 77, 274 (1975).

5. A. Abou E1-Kheir and A. K. S. Ahmad, Elemiszervizsgalati Kozl., 20, 315 (1974); cf. Chem. Abstr., 83, 45071d (1975).

6. S. Ikeda, Analyt. Letters, $\underline{7}, 343$ (1974).

7. S. S. M. Hassan, Z. analyt. Chem., 270, 125 (1974).

8. W. Sellg, Microchem. J., 16, 385 (1971).

9. C. K. Stah1 and S. SIggia, Anaz. Chem., 28, 1971 (19756).

10. M. K. Papay, K. Toth, and E. Pungor, Analyt. Chim. Acta, 56, 291 (1971).

11. Pungor, E., K. Toth, and M. K. Papay, Chem. Anal. (Warsaw), 17, 947 (1972).

12. M. K. Papay, K. Toth, and E. Pungor, Ion-Selec. Electrodes, Symp. 1972, 225; cf. Chem. Abstr., 79, 26917k (1973). 
13. M. Kucsera-Papay, Kem. KozZem., 39, 35 (1973); cf. Chem. Abstr., 79, 73358p (1973).

14. V. P. Izvekov, M. Kucsera-Papay, K. Toth, and E. Pungor, Analyst, 97, 634 (1972). 


\section{Physiodogically Active Compounds}

This section describes the application of ISE's to the analysis of a variety of physlologically active compounds such as proteins, vitamins, etc. Some physiological compounds may also be found in preceding sections, as shown in the following summary :

\begin{tabular}{|c|c|}
\hline Compound & page \\
\hline $\begin{array}{l}\text { Thyroxin, } 3,3,5^{\prime} \text {-triiodo- } \\
\text { L-thyronine }\end{array}$ & 38 \\
\hline $\begin{array}{l}\text { Chloride salts of some drugs, } \\
\text { chlorine in pharmaceuticals }\end{array}$ & $38-39$ \\
\hline Chlorine-containing pesticides & 42 \\
\hline $\begin{array}{l}\text { Antiseptics, artificial } \\
\text { sweeteners }\end{array}$ & 56 \\
\hline Amino acids & $56-57$ \\
\hline Acetylcholine & 65 \\
\hline $\begin{array}{l}\text { Diphenhydramine, dextro- } \\
\text { methorphanium cation }\end{array}$ & 66 \\
\hline $\begin{array}{l}\text { Choline, acetylcholine, } \\
\text { topine, scopolamine, } \\
\text { atropine }\end{array}$ & 67 \\
\hline Glutathione, cysteine & 80 \\
\hline $\begin{array}{l}\text { Trypsin, ribonuclease, } \\
\text { insulin, etc. }\end{array}$ & 89 \\
\hline Carbohydrates & 101 \\
\hline
\end{tabular}

Chymotrypsin. A simple direct titration of active $\alpha$-chymotrypsin rakes use of a fluoride ISE. 1 Measurement of as little as $0.03 \mathrm{~m} M$ of the enzyme is possible wlth about $3 \%$ preciston. The specific reagent dIphenylcarbamy1 fluoride (DPCF) inactivates the enzyme, liberating an equimolar amount of fluoride lon that is determined by the ISE. The reaction is

$$
\begin{aligned}
& \mathrm{DPCF}+\text { chymotrypsin } \rightarrow \cdot \\
& \text { wPC-chymotrypsin }+\mathrm{F}^{-} .
\end{aligned}
$$

This technique is three times more sensitive than previously used methods. Standacı curves were constructed by determining emf's at various fluoride concentrations in the presence of equimolar quantities of chymotrypsin. Solutions ranged from 50 to $0.002 \mathrm{mM}$. They also contained $1 \%$ methanol, which was required to keep the DPCF in solution. Cyanogenic Glycosides. Cyanide resulting from the hydrolysis of cyanogenic glycosides in Sudan grass has been determined with a cyanide ISE. ${ }^{2}$ After accelerated hydrolysis with emulsin, the cyanide was determined by direct potentiometric measurement in the hydrolyzate. The medium was $0.05 M$ in potassium acid phthalate and $0.022 \mathrm{M}$ in sodium hydroxide. A linear response was obtained over the range of $10^{-3}$, to $10^{-6} M$ cyanide.

Cyanocobalamine. Another application of the cyanide ISE is in the analysis of cyanocobalamine. ${ }^{3}$ Equimolar amounts of hydrogen cyanide are liberated either by quantltative reduction or by illumination. The reduction can be carrled out with ascorbic actd, with stannous chloride 
plus hydrochloric acid, or wit" calciuro hypophosphice plus either hydrochloric or sulfuric actd, under reflux. The illumination method exposes a solution buffered with phosphate-citric acid buffer ( $\mathrm{pH} 3$ to 5) to two $500-\mathrm{W}$ Dulbs for $60 \mathrm{mIn}$ while cooling the solution. In both methods, the liberated hydrogen cyanide is swept into a buffer solution (0.1M potassium nitrate adjusted to pH 11 with $0.01 M$ sodium hydroxide) by a stream of nitrogen. The $\mathrm{pH}$ of the standardizing and measured solution must be kept above 10.5 , since the electrode responds only to the cyanide ion, not to hydrogen cyanide. The cyanide may also be titrated potentiometrically with silver nitrate. In this case, two inflections are obtained, either of which can be used for the calculation of the endpoint. The error of this method is within $\pm 5 \%$. The electrode is condicioned by soaking in a buffer solution $0.1 M$ in potassium nitrate adjusted to $\mathrm{pH} 11$ with sodium hydzuxide for $5 \mathrm{~h}$.

Choline Esters. Croline and acey1choline have been discussed previously (pp. 66, 68). Baum et al. 4,5 described an electrode for measuring the concentration of choline and its esters. The membrane is prepared from a solution of acetylcholine tetra-p-chlorophenylborate in a phthalate ester wich serves as plasticlzer for poly (vinyl cinlorife). $A$ disc cut from the membrane film is placed in the bottom cap of a Co rning liquid membrane assembly. Potential response curves are shown in $\mathrm{FIg} .29$. The electrode can be used for the assay of acetylcholine esterase activity.

Ephedrine and Methylephedrine.

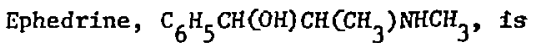
a drug used to cause a rise in blood pressure upon intravenous infection. Tukamachi et al. ${ }^{6}$ have developed ISE's with a liquid membrane or polyvinyl chloride matrix membranes responsive to dl-methylephedrine and ephedrine. An organic solvent solution of the tetraphenylborate salt of the cation was used as the liquid membrane, which was put into an orton model 92 electrode óarrel.

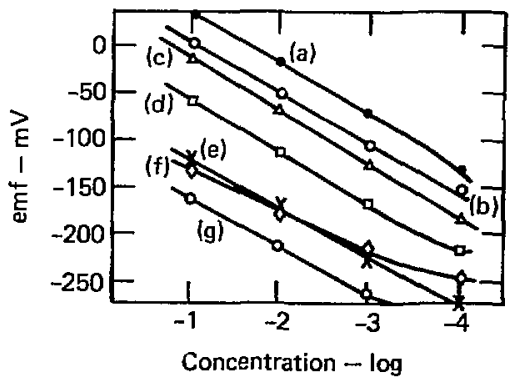

Fig. 29. Potential response curves of the polymer membrane electrode: (a) butyrylcholine; (b) acety 1B-methylcholine; (c) acetylcholine;

(d) choline; (e) anmonium; (f) potassium; and (g) sodium. Source: Ref. 4, used with permission. 
The polyvinyl chloride natrix membrane was prepared as follows: $\Lambda 20^{\circ}$. (w/w) of PVC in tetrahydrofuran, dioctylphthalate, and the tetraphenylborate salt of the cation were mixed in the weight ratio $25: 10: 2$. The mixture was spread on a glass plate and dried by evaporation. A disc cut from this membrane was affixed tc an Orion model $92 \mathrm{elec}$ trode barrel.

The methylephedrine ISE exhibited an approximately Nernstian response down to $10^{-4} \%$. The ephedrine ISE showed Nernstian response down to $10^{-3} M$. The emf 's of both ISE's were independent of $\mathrm{pH}$ from 1.5 to 8.0 . The interference of sodium, potassium, ammonium, and calcium ions was extremely low for both ISE's. Caffeine, antipyrine, aspirin, aminopyrine, vitamin $C$, and sulpyrine, which are usually present in drugs, did not interfere with the methylephedrine ISE. Diphenhydramine and chlorpheniramine lons, however, interfered seriously. The polyvinyl chloride membrane eléctrode was also used as the indicator electrode in the precipltation titration of methylephedrine with tetraphenylborate.

Saccharin. Hazemoto et al. ${ }^{7}$ prepared an ISE responsive to saccharin (o-sulfobenzolc acid Inide). The Ilquid membrane was prepared as follows: $60 \mu$ mole of bathophenanthroIIne was dissolved in $100 \mathrm{ml}$ nttro- benzene, $50 \mathrm{ml} 3 \times 10^{-4} \mathrm{~K}$ aqueous ferrous ammonfum sulfate was added to form the Iron(II) chelate of bathophenanthroline. Then, $200 \mathrm{ml}$ $10^{-2} M$ aqueous sodium saccharin ::1s added and the mixture was shaken for 10 min. The nitrobenzene solution was separated from the aqueous phase and used as the liquid membrane. The ISE prepared with this membrane showed a linear response of $57 \mathrm{mV} /$ decade over the range of $10^{-1}$ to $10^{-5} \mathrm{M}$. Other sweetening substances such as saccliarose, glucose, sodium cyclamate, and sorbitol did not interfere. A stable emf was developed within 2 to $3 \mathrm{~s}$, and was stable for at least $1 \mathrm{~h}$. The emf was not appreciably affected by $\mathrm{pH}$ variations between 3 and 10 . The presence of large amounts of benzoic acid and of salicylic acid causes appreciable errors. These sompounds can be masked by aluminum sulfate, or by passing the sample solution through a Sephadex column.

Vitamins. Ishibashi et az. ${ }^{8,9}$ prepared ISE's for vitamin $B_{1}$ (th1amine) and $B_{6}$ (pyridoxine). The liquid membranes weje prepared by using ion-association extraction systems. Vitamins $B_{1}$ and $B_{6}$ were extracted into organic solvents such as 1,2-dichioroethane or nitrobenzene with tetraphenylborate or dipicrylamine respectively, in an aqueous medium at $\mathrm{pH} 3$ to 5 . The organic 
solutions were used as the vitaminsensitive membranes which exhibited near Nerstian response from $10^{-2}$ to $10^{-5} \mathrm{H}$. The electrodes yielded high selectivities for the vitamin ions over sodium, potassium, and ammonium tons.

Proteins. Alexander and Rechnitz ${ }^{10,11}$ used the highly sensttive response of the silver sulfide ISE to sllver fons and sulfurcontaining functional groups to provide direct potentlometric measurement of individual proteins and protein mixtures in serum. A procedure was developed to minimize protein polsoning of the electrode and to permit its long-term use of protein measurement in isotonic saline solution. The results of studies on native and denatured proteins, deprotelnation of serun samples, and denaturation kinetics were reported. Also, a flow system is described for the automatic determination of protein in serum. The automated method can be used to measure total sulfurcontaining proteins or to distinguish between individual proteins on the basis of differences in reactivity.

\section{Miscellaneous}

Colloid Titration. Ishibasht et $a l .{ }^{12}$ have used a cyanide ISE (Orion 94-06A) In conjunction with a doublejunction reference electrode to detect the endpoint in the titration of negatively charged colloids.
Iodide at a concentration of .. jout $10^{-5} d$ is used as the findicator. The electrode systew monitors the change In lodide fon activity in the titration of polyvinyl silfate with tetradecyldimethylbenzylammonfum chloride (Zephiramine). The decrease of the activity of the lodide indicator, starting immediately after the equivalence point is passed, Is shown in Ffg. 30. It was found that the cyanide ISE shows an Ideal Nernstian response to fodide ion.

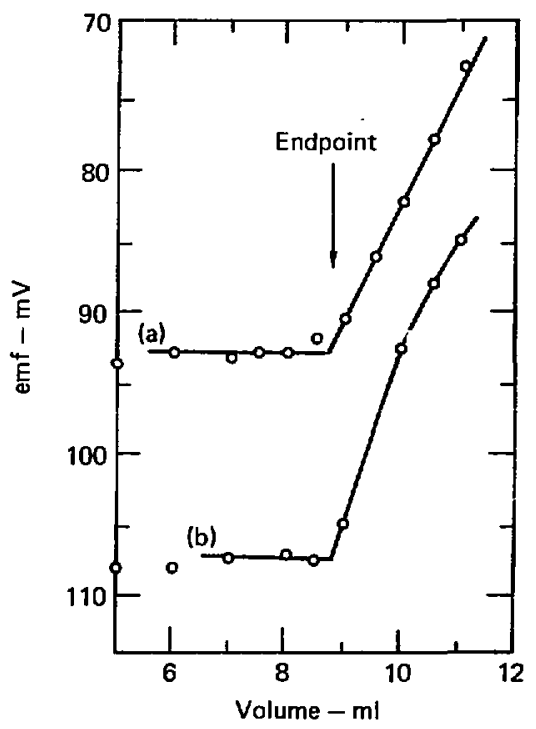

Fig. 30. Potentiometric titration of PVS-K with Zephiramine in the presence of lodide ion 1ndicator. Indicator concentration $=\left(\right.$ a) $6.5 \times 10^{-6} \mathrm{M}$; and (b) $1.0 \times 10^{-5} \mathrm{M}$. Source: Ref. 12, used with permission. 
Miscellaneoug Druga. Kina et at. ${ }^{9}$ have used liquid methranes similar to those previously described for vitaming $B_{1}$ and $\mathrm{B}_{6}$ for several. drug andons and cations, namely methacholine, neost Igmine, N-1.-methyl nicotinamide, diphenhydramine, p-amino-sal1cylic acid, and sallcylic act.d.

The liquil membranes of the electrodes were prepared by using the Ion-association extraction method. 8 Sodium tetraphenylborate (IPB) or dipicrylainine (hexyl) was used as the extractant of a drug cation.
The crystal violet cation (CV) of: the ferroln compound of the 1ron che1nts of o-shenanthroline (Phen) or bathophenanthroline (Bphen) was used as the extractant of the drus anfon. Nftrobenzene (NB) or 1,2dichloroethane (DCE) was used as the membrane solvent; the concentration of the liquid membrane was $1 \% 10^{-4} \mathrm{H}$. The electrode performances, Including the selectivfty coeffictents, are sumunarized In Table 47. Nernstian response was obtained down to $10^{-4}$ to $10^{-5} \mu$.

Table 47. Performance of the drug Ion-sensitive electrodes.

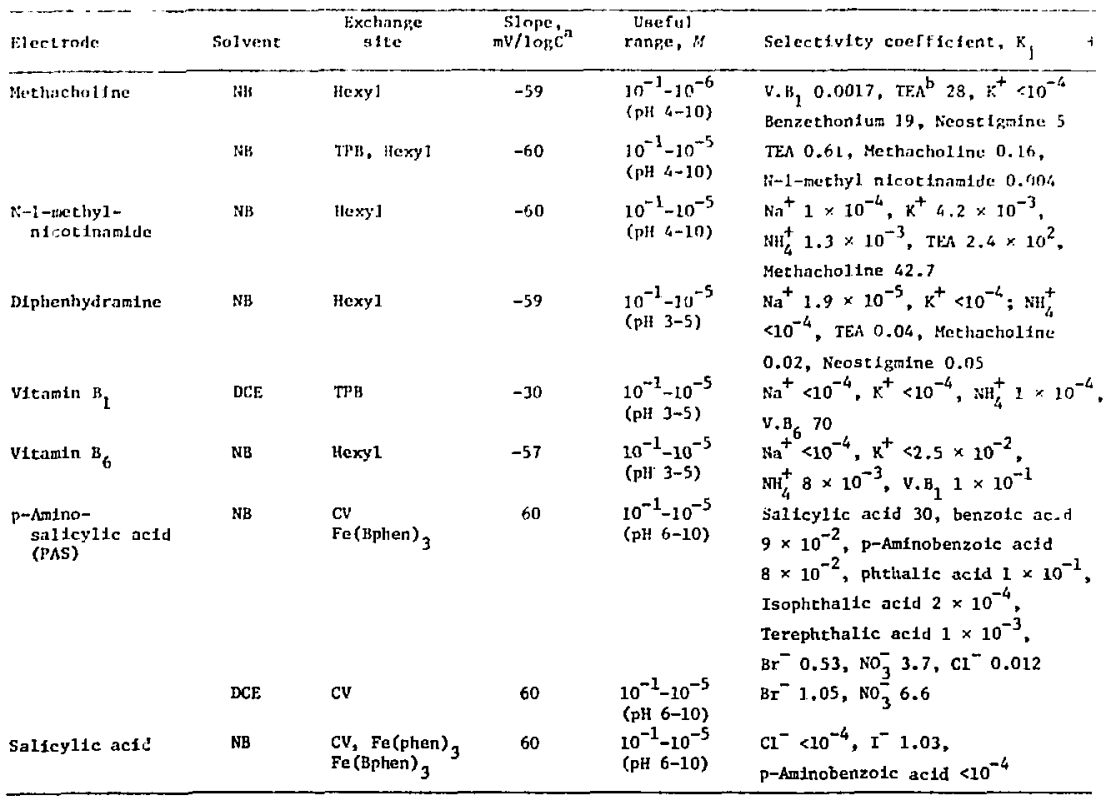

\footnotetext{
${ }^{a} \mathrm{C}$ denotes the molar concentracton of drug $10 \mathrm{n}$.
}

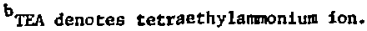


The methacholine ISE was also uset in the potentiometric titration of methacholine chloride with sodium tetraphenylborate. The results agreed well with the argentimetrlc titration of the chloride ion.

1-F1uoro-2,4-d1n1trobenzene. Zentner ${ }^{13}$ found that the fluoride
ISE also responds to non-1onic 1fluoro-2,4-dinftrobenzene and to caiclum 1cns. A IInear relationship was found between enf and the logartihm of the concentration of 1-fluoro-2,4dinttrobenzene. However, the enalogous chlnro compound, 1-chloro-2,4dinitrobenzene had no effect on the chloride ISE.

\section{References}

1. B. F. Erlanger and R. A. Sack, Anal. Biochem., 33, 318 (1970).

2. W. J. Blaede1, D. B. Easty, L. Anderson, and T. L. Farrel1, Anal. Chem., $\underline{43}, 90$ (1971).

3. Y. M. Dessouky and E. Pungor, Analyst, 96, 442 (1971).

4. G. Baum, M. Lynn, and F. B. Ward, Analyt. Chum. Acta, 65, 385 (1973).

5. G. Baum and M. Lymn, U.S. Pat. 3,840,452 (8 oct. 1974); cf. Chem. Abstr., 82, 121269w (1975).

6. K. Fukamacht, R. Nakagawe, M. Mor1moto, and N. Ish1bash1, Bunseki Kagaku, 24, 428 (1975).

7. N. Hazemoto, N. Kamo, and Y. Kobarake, J. Assoc. Off. AnaZ. Chem., 57, 1205 (1974).

8. N. Ishibashi, K. Kina, and N. Maekawa, Chem. Letters, 1973, 119.

9. K. Kina, N. Maekawa, and N. Ishibashi, BulZ. Chem. Soc. Japan, 46, 2772 (1973).

10. P. W. Alexander and G. A. Rechnicz, Anal. Chem., 46, 250 (1974).

11. P. W. Alexander and G. A. Rechnitz, Anal. Chem., 46, 860 (1974).

12. N. Ishibashi, K. KIna, and K. Tamura, Anal. Letters, 8, 867 (1975).

13. H. Zentner, Chem. Ind. (London), 1973, 480. 


\section{ION-SELECTIVE ELECTRODES AS DETECTORS IN CHROMATOGRAPHY}

\section{Gas-Chromatography}

ISE's have recently come into use as detectors in gas-chromatography for the determination of sulfux, chlorine, fluorine, and nitrogen in organic compounds. The most significant contribution to this field has been made by the series of papers published by Kojima and co-workers. ${ }^{1-7}$ With the exception of one paper (Ref. 2), however, this rork was published in Japanese. Although English abstracts are given in these papers and are available from Chem. Abstr. or Analyt. Abstr., it is our opinion that translation of this work into English will stimulate additional activity in this field.

In their first paper Kojima et $\alpha{ }^{1}{ }^{1}$ described the design and performance of ISE detectors for organic sulfur and chlorine-containing compounds. The compounds were pyrolyzed in hydrogen carrier gas over a nickel or platinum catalyst at 800 to $1000^{\circ} \mathrm{C}$. The sulfur-containing mo1etles were converted into hydrogen sulfide, and the chlorine-containing noieties were converted Into hydrogen chlortde. The gases were absorbed in an alkaline solution and monttored In a flow-cell. Hydrogen sulfide was monitored by a silver sulfide ISE (Orion 94-17), while hydrogen chloride was monitored ty a chloride ISE (Orton 94-16). No other common elements were found to interfere. The potentiometric output from the cell was recorded after conversion to a signal that was proportiond $1=0$ the sulfide or chloride concentration by an antilogarithmic converter. The response of the detector to sulfurcontaining compounds was about 2000 times that of an equal amount of other organic compounds; 0.0001 umole of dimethyl disulfide could be detected. The response was linear from $2 \times 10^{-10}$ to $1 \times 10^{-7} M$ dimethy 1 disulfide and from $1 \times 10^{-8}$ to $1 \times 10^{-6} M 1,2-$ dichloroethane. Figure 31 shows a chromatogram obtained by a mixture of dimethylsulfj.de, 1,1-dichlojoethane, ethyl acetate, allyl iodide, and 1,1-dibromoethane. The ordinary non-selective chromatogran In Fig. 31 (a) was obtained by passing the components through a hydrogen-flame ionization detector while bypassing the hydrogenolysis tube. Figure 31 (b) shows the selective detection of the sulfurcontaining compound and Fig, 31 (c), similarly, the detection of the halogen-containing compounds by the 

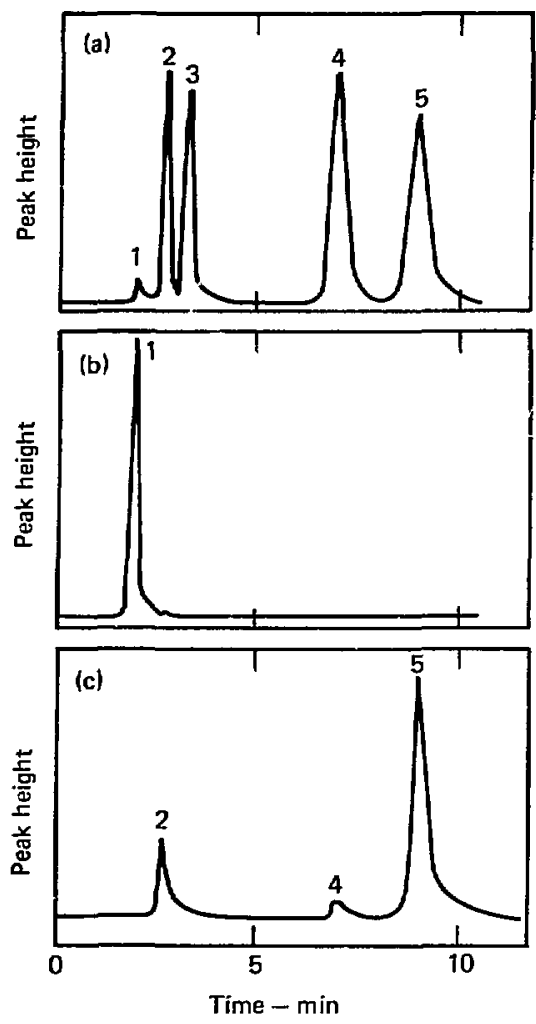

Fig. 31. Chromatogram of a test mixture: (a) nonselective detection by use of FID; (b) selective detection of sulfur compound by use of sulfide ton electrode detector; and (c) selective detection of halogen compounds by use of chloride ton electrode detector. 1: dimethy1sulfide (1). 2: 1,1-Dichloroethane (10). 3: Ethy1 acetate (10). (4): Ally1 todide (10). 5: 1,1Dibronoethane (10). ( ) = Mole rat1o; Colum $=10 \%$ silicone $\mathrm{DC}$ 550/Chromosorb V (80-100 mesh), $4 \mathrm{~m}$; Colum temperature $=75^{\circ} \mathrm{C}$; Carrier gas $=42 \mathrm{mi} / \mathrm{min}$. Source: Ref. 1, used wth permission. chloride ISE. It is evident that the chloride ISE also responds to iodide and bromide. Simflar results were obtained from chromatographing the following mixtures:

- n-Pentane (10), acetonitrile (10), methy1 ethy1 ketone (10), nitromethane (10), nitroethane (10), and dimethyl disulfide (1). *

- Thiophene (1), pyridine (10), chlorobenzene (10), o-xylene (10), and anisole (10).

- Ethylbenzene (10), bromobenzene (10), anfline (10), methyl benzoate (10), and phenyl isothiocyanate (1).

A comparison of the responses obtained from several sulfurcontaining compounds is shown in Table 48 and for several chlorinecontaining compounds in Table 49.

Fluorine compounds are difficult to detect selectively. Heretofore, they were detected by monitoring the intensity of the atomic emission spectrum of fluorine using a dcdischarge detector. 7 In the gaschromatographic method of Kojima et $a l_{.},{ }^{2}$ the sample components are separated on a column using hydrogen as the carrier gas. The effluent is passed through a platinum or quartz tube at $1000^{\circ} \mathrm{C}$ for hydrogenolysis.

\footnotetext{
${ }^{*} M$ ratios given in parentheses
} 
Table 48. Comparison of responseg obtafned from several sulfur compounds.

\begin{tabular}{|c|c|c|c|c|c|c|}
\hline \multirow[b]{2}{*}{$\begin{array}{l}\text { Sample } \\
M \text { ratio }\end{array}$} & \multicolumn{3}{|c|}{ Aliphatic compounds } & \multicolumn{3}{|c|}{ Aromat ic compounds } \\
\hline & $\begin{array}{l}\text { Thiophene } \\
1\end{array}$ & $\begin{array}{l}\text { Dimethyl } \\
\text { disulfide } \\
1\end{array}$ & $\begin{array}{l}\text { Ethy1 } \\
\text { thio- } \\
\text { cyanate } \\
1\end{array}$ & $\begin{array}{l}\text { Thiophene } \\
1\end{array}$ & $\begin{array}{c}\text { Thio- } \\
\text { anisole } \\
1\end{array}$ & $\begin{array}{l}\text { Pheny1 } \\
\text { isothio- } \\
\text { cyanate } \\
1\end{array}$ \\
\hline $\begin{array}{l}\text { Number of sulfur } \\
\text { atoms }\end{array}$ & 1 & 2 & 1 & 1 & 1 & 1 \\
\hline $\begin{array}{l}\text { Ratio of peak } \\
\text { areas }\end{array}$ & $\begin{array}{l}0.45 \\
0.46 \\
0.46 \\
0.44 \\
0.45 \\
0.42 \\
0.45\end{array}$ & $\begin{array}{l}1 \\
1 \\
1 \\
1 \\
1 \\
1 \\
1\end{array}$ & $\begin{array}{l}0.45 \\
0.47 \\
0.47 \\
0.44 \\
0.47 \\
0.48 \\
0.45\end{array}$ & $\begin{array}{l}1.01 \\
1.11 \\
1.01 \\
1.05 \\
1.05 \\
1.01 \\
1.11\end{array}$ & $\begin{array}{l}1 \\
1 \\
1 \\
1 \\
1 \\
1 \\
1\end{array}$ & $\begin{array}{l}0.95 \\
0.99 \\
1.09 \\
1.03 \\
1.02 \\
1.04 \\
1.04\end{array}$ \\
\hline Mean & 0.447 & 1 & 0.461 & 1.050 & 1 & 1.023 \\
\hline
\end{tabular}

Fluorine is converted to hydrogen fluoride, which is dissolved in an absorbing solution containing TISAB and passed into a microcell equipped with a fluoride ISE. The changes in fluoride ion concentration are detected by the corresponding changes in emf. At constant lonic strength, a Nernstian relationship exists between the electrode potential and the logarithm of the fluoride ion concentration. The differeuce in potential between the detecting electrode and a reference electrode was fed into an antilog converter circuit and a signal proportional to the

Table 49. Comparison of responses obtained from several chlorine compounds.

\begin{tabular}{|c|c|c|c|c|c|c|}
\hline & \multicolumn{3}{|c|}{ Aliphatic compounds } & \multicolumn{3}{|c|}{ Aromat1c compounds } \\
\hline Sample & $\begin{array}{l}\text { 1,1-Dichloro- } \\
\text { ethane }\end{array}$ & $\begin{array}{l}\text { Trichloro- } \\
\text { ethylene }\end{array}$ & $\begin{array}{l}1,1,2,2-\text { Tetra- } \\
\text { chloroethylene }\end{array}$ & $\begin{array}{l}1,1,2,3 \text {-Tetra- } \\
\text { chloruethylene }\end{array}$ & $\begin{array}{l}\text { Chloro- } \\
\text { benzene }\end{array}$ & $\begin{array}{l}\text { p-Chloro- } \\
\text { toluene }\end{array}$ \\
\hline$M$ ratio & 1 & 1 & 1 & 1 & 1 & 1 \\
\hline $\begin{array}{l}\text { Number of } \\
\text { chlorine atoms }\end{array}$ & 2 & 3 & 4 & 4 & 1 & 1 \\
\hline Ratio of peak areas & $\begin{array}{l}1 \\
1 \\
1 \\
1 \\
1 \\
1 \\
1\end{array}$ & $\begin{array}{l}1.41 \\
1.57 \\
1.44 \\
1.55 \\
1.34 \\
1.42 \\
1.46\end{array}$ & $\begin{array}{l}1.89 \\
2.14 \\
2.05 \\
2.26 \\
1.95 \\
1.90 \\
1.97\end{array}$ & $\begin{array}{l}1 \\
1 \\
1 \\
1 \\
1 \\
1 \\
1\end{array}$ & $\begin{array}{l}0.28 \\
0.26 \\
0.25 \\
0.25 \\
0.25 \\
0.25 \\
0.27\end{array}$ & $\begin{array}{l}0.30 \\
0.27 \\
0.29 \\
0.28 \\
0.28 \\
0.28 \\
0.30\end{array}$ \\
\hline Mean & 1 & 1.456 & 2,021 & 1 & 0.259 & 0.286 \\
\hline
\end{tabular}


fluoride Ion concentration was

recorded. A small amount of sodium

fluoride was added to the absorption solution to make the fluoride concentration approximately $10^{-5} M$ in order to use the linear response range of the electrode (Orion 94-09A).

The response time of the detector was about $10 \mathrm{~s}$ for $10^{-5} \mathrm{M}$ fluoride, and several seconds when it was more than $10^{-4} \mathrm{M}$. Although such slow response distorts the early peaks slightly, it has negligible effect for peaks having retention times greater than $5 \mathrm{~min}$. The advantages of the ISE detector for fluoride are a high selectivity of 10,000 times or more with an extremely high sensitivity. The limit of detection for fluorobenzene was $0.05 \mathrm{nM}$. The drift of the baseline was $0.02 \mathrm{mV} / \mathrm{h}$ with good stability.

F1gure 32 shows a chromatogram obtained by injecting 0.1 to $0.2 \mu 1$ of a mixture of $0.01 M$ each of ethylmercaptan, n-octane, 1,2-dibromoethane and 1 -nitropropane, and $0.1 M$ of ethy 1 trifluoroacetate. The ordinary nonselective chromatogram in Fig. 32 (a) was obtained by passing the romponents from the separation column through a hydrogen flame ionization detector while by-passing the hydrogenolysis tube. Figure 32 (b) shows the chromatogram obtained when the sample was subjected to hydrogenolysis and absorbed In TISAB solution.

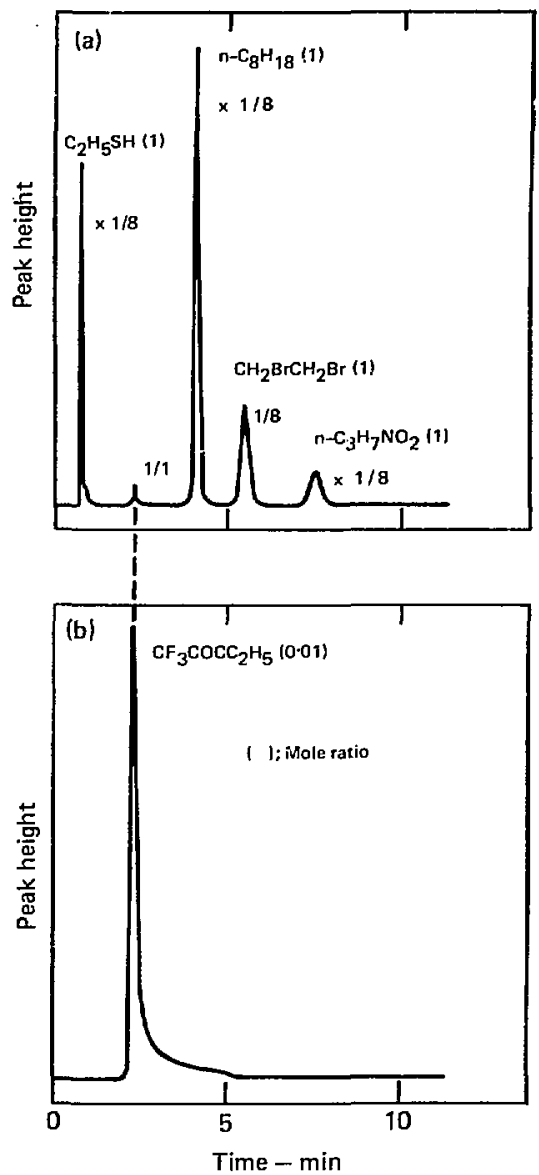

Fig. 32. Chromatogram of a test mixture: (a) nonselective detection by use of FID; and (b) selective detection of fluorine compound by use of fluoride ion electrode detector. Column = Durapak-Carbowax 400/Porasil C(100-120 mesh), $1 \mathrm{~m}$; Column temperature $=90^{\circ} \mathrm{C}$; Carrier gas, $\mathrm{H}_{2}=28 \mathrm{ml} / \mathrm{min}$. Source: ReF. 2 , used with permission. 
Using the same procedurs, 100 $\mu$ mole of $1,1,2,2$-tetrachloro-1,2difluoroethane was detected selectively in a mixture with $10 \mathrm{~m}$ mole each of ethyl todide, n-propyl acetate, 1,1,2-trichloroethane and ethyl thiocyanate.

A similar chromatogram vas obtained when the components were all aromatic, as with a mixture of $100 \mathrm{~m}$ mole each of ethylbenzene, bromobenzene, benzonitrile and thioantsole and $100 \mu$ mole o-fluorotoluene. For further confirmation of the applicability of the gaschromatographic procedure to aromatic compounds a mixture of $10 \mu$ mole each of o-xylene, o-chlorotoluene, methyl benzoate, phenyl isocyanate and $100 \mu$ mole of benzotrifluoride were chromatographed. These experiments confirmed the selective detection of fluorine compounds.

For quantitative work, three groups were selected:

- Fluorobenzene, o-fluorotoluene, and benzotrifluoride.

- 1,1,2,2-tetrachloro-1,1difluorethane, o-fluor toluene and $\mathrm{p}$-chlorofluorobenzene.

- Perfluoromethylcyclohexane $\left(\mathrm{C}_{6} \mathrm{~F}_{11} \mathrm{CF}_{3}\right)$, perfluorobenzene, and m-difluorobenzene.

The mixtures were diluted with nhexane and injected Into a column of Durapak-Carbowax 400/Porasil C (100200 mesh) $1 \mathrm{~m}$ in length, at $60^{\circ} \mathrm{C}$, and chromatographed. Relative neak heights were determined by the method sf cutting out recorded peaks and weighing the paper. In each case, the average of the experimentally-determined ratio of peak areas was close to the theoretical value.

The design and performance of a gas-chromatographic detector for nitrogen compounds was also described by Kojima et $a l^{3}$ The sample components were resolved on a gaschromatographic column using hydroggen as the carrier gas. The effluent was passed at $820^{\circ} \mathrm{C}$ through a quartz tube packed with a nickel catalyst. The nitrogen was converted into ammonia, which was absorbed in a slow stream of a buffer solution. This solution was passed through a flow-cell containing a monovalent cation-sensitive electrode. The difference in emf between this electrode and a reference electrode was fed into an antilog converter circuit, and a signal proportional to the ammonium ion concentration was recorded. The chromatogram shows only peaks due to nitrogen compounds.

\section{Selective detection of nitriles,} thiocyanates, and heterocyclic nitro compounds was accomplished. A sample chromatogram is shown in Fig. 33. The detector responded tu nitrogen compounds approximately 2000 times 

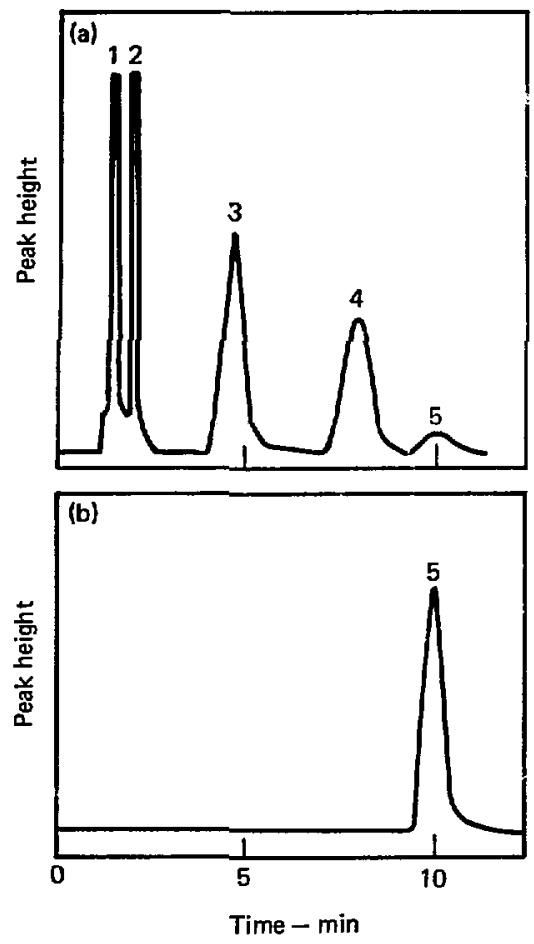

F1g. 33. Chromatogram of a test $\mathrm{mix}-$ ture: (a) nonselective detection by use of FID; and (b) selective detection of nitrogen compound by use of cation electrode detector. 1: o-Xylene (10). 2: o-Chlorotoluene (10). 3: Thioanisole (10). 4: 1,2,3-Trichlorobenzene (10). 5: m-Chlorobenzonitrile (1).

( ) = Mole ratio; Column temperature $=150^{\circ} \mathrm{C}$. Source: Ref. 3, used with permission.

more strongly than to chlorinecontaining compounds. The 1imit of detection for nitromethane was 0.005 umole at a signal-to-noise ratio of 2. For nitromethane, there was a linear response from $5 \times 10^{-10}$ to $1 \times 10^{-7} M$. A full-scale response was obtained for the pesticide Diazinon (shown below),

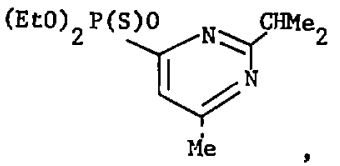

while other pesticides containing chlorine and oxygen were not detected. Kojima et $a r^{4}{ }^{4}$ also developed a method for the identification and determination of thiophene compounds. They used reaction gas-chromatography In conjunction with a sulfide ISE detector. As in the previous papers, the sample mixture was resolved on a column by using hydrogen as the carrier gas. The effluent was passed through a postcolumn reactor packed with a platinum catalyst and heated to $900^{\circ} \mathrm{C}$; the sulfur-contsining components were reduced to hydrogen sulfide. The gas was introduced into an absorption tube containing a solution such as $0.1 M$ sodium hydroxide, $0.1 M$ sodium nitrate, $0.1 M$ sodium sulfite, and $10^{-5} M$ sodium sulfide. The solution emerging from the absorption tube was passed into microcell equipped with a sulfide ISE to detect changes in sulfide lon concentration. 
The signal, which was directly proportional to the sulfide concentration, was recorded. The chromatogram thus obtained shows only the peaks of sulfur-contalning compounds.

Nonthiophenic compounds, such as tert-butyl mercaptan, $\mathrm{n}$ -

pentylmercaptan, methylthiocyanate, methylisothiocyanate, cyclohexyl mercaptan, carbon disulfide, tert-buty 1 disulfide, dimethyl disulfide, thiocyclopentane, and phenyl isothiocyanate, were completely converted to hydrogen sulfide in the reaction column at $\leq 700^{\circ} \mathrm{C}$. Thiophenic compounds such as thiophene, 3-methylthiophene, benzo (b) thiophene, and dibenzothiophene were completely decomposed at $900^{\circ} \mathrm{C}$.

With this method, sulfur compounds can be easily differentiated from other compounds, and thiophenic compounds can be easily distinguished from other sulfur-containing compounds by comparing the two chromatograms of samples hydrogenolized at $700^{\circ}$ and at $900^{\circ} \mathrm{C}$. A sample chromatogram is shown in FIg. 34.

Kojima et al. ${ }^{5}$ investigated the selective detection of mercaptans using a sulfide ISE. The components eluted from the gas-chromatogrphic colum are introduced into an absorption tube in wich a silver nitrate solution ( 1 to $100 \times 10^{-5} \mathrm{M}$ ) flows at a constant rate. The solution emerging from the absorption tube is
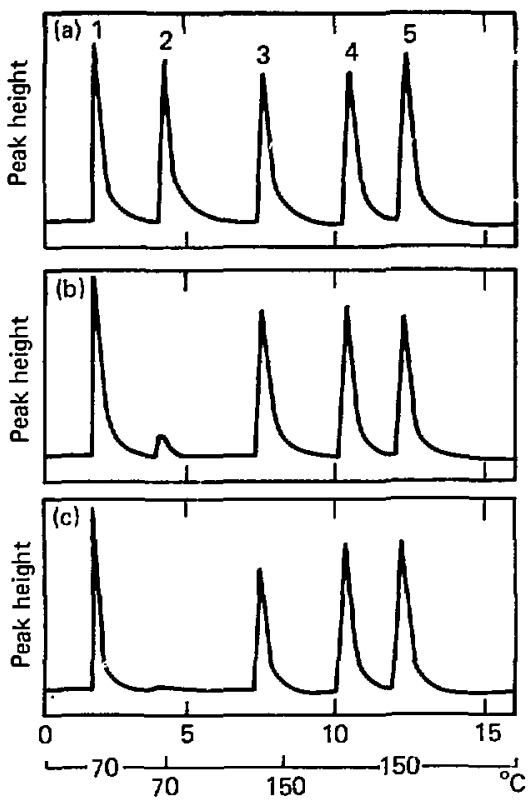

Time - min

Fig. 34. Selective detection of nonthiophenic compour.ts. Hydrogenolysis temperature $=$ (a) $900^{\circ} \mathrm{C}$;

(b) $750^{\circ} \mathrm{C}$; and (c) $700^{\circ} \mathrm{C} .1$ : t-Butyl mercaptan (1). 2: 3-Methy 1thlophene (1). 3: Diethyl disulfide $(0.5)$. 4: Thioanisole (1). 5: Pheny1 isothiocyanate (1). ( ) = Mole ratio; Colum $=5 \%$ Silicone DC 550/Chromosorb W (80100 mesh), $2 \mathrm{~m}$; Carrier gas, $\mathrm{H}_{2}=$ $30 \mathrm{ml} / \mathrm{min}$. Source: Ref. 4, used with permission.

passed Into a microcell equipped with a sulfide ISE. The silver ton concentration decreases by forming insoluble mercaptide, when mercaptans are present in the eluant. The changes in silver Ion concentration are detected by the corresponding 
changes in emf, which are converted by an antilogarithruic converter and recorded. Thus, the chromatogram shows only mercaptan peaks. In order to detect alz sulfur compounds, a postcolumn reactor was connected to the chromatographic column to convert all sulfur compounds to hydrogen sulfide, as previously described. ${ }^{1}$ Thus mercaptans and all sulfurcontaining compounds can be distinguished from the other compounds. This is demonstrated in Fig. 35 . Pyridine is also somewhat sensitive to this detector; however, the sensitivity of mercaptans was $>200$ times that of pyridine and $>100$ times that of a11 other compounds. The detectIon 1imit for mercaptans was approximately 0.01 nmole. Linear response was obtained up to $3 \times 10^{8} \mathrm{M}$.

Kojima et $a r^{6}$ described a selective gas-chromatographic detector equipped with two ISE's to allow the simul taneous and selective determination of chlorine- and fluorinecontaining compounds through twochannel operation. Components eluted from the colum were passed through a platinum tube at 1000 to $1080^{\circ} \mathrm{C}$, where they undergo hydrogenolysis. As described above, ${ }^{1}$ chlorinecontaining compounds are converted to hydrogen chlorlde, and fluorinecontaining compounds are converted to hydrogen fluoride. These gases are dissolved in a slow stream of an
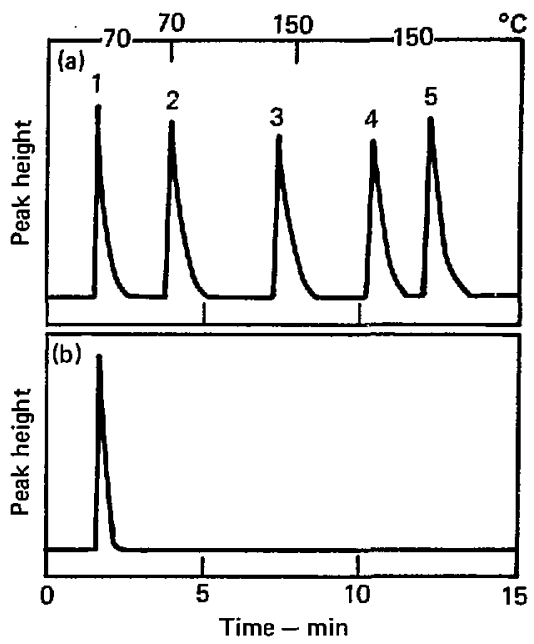

Fig. 35. Selective detection of mercaptan: (a) detection of sulfur compounds with hydrogenolysis reactor; and (b) selective detection of mercaptan without hydrogenolysis reactor. 1: t-Butyl mercaptan (1). 2: 3-Methylthiophene (1). 3: Diethyl disulfide $(0.5)$. 4: thioanisole (1). 5: Phenyl isothiocyanate $(1) .()=$ Mole ratto; Column $=5 \%$ Silicone DC $550 /$ Chromosorb W ( $800-100 \mathrm{mesh}), 2 \mathrm{~m}$; Carrier gas, $\mathrm{H}_{2}=30 \mathrm{~m} 1 /$ min. Source: Ref. 5 , used with permission.

absorption solution. The chloride and fluoride concentrations are monItored by a chloride and fluoride ISE. As described in the preceding papers, the potentiometric output of each ISE is converted first into a signal that is proportional to the concentration of each ion, then by an antilogarithmic converter to be recorded by a dual-pen recorder. For 
a mixture, two chromatograms are recorded simultaneously, one spectflc for the chlorine- and the other for the fluorine-containing compounds, as shown in Fig. 36.

Since the detector monitors the same effluent, the response ratio (defined as the peak area of the chromatogram of the chloride channel divided by that of the fluorlde channel for the same compound) can be precisely determined. Data obtained with eight compounds containing chlorine and fluorine showed that the $\mathrm{Cl} / \mathrm{F}$ atomic ratio in a molecule eluted from a gas-chromatographic column can be accurately determined from the response ratio. An example of the response ratios is shown in Table 50.

Selber, ${ }^{8}$ in a survey paper, examined the use of fluoride, chloride, and sulfide ISE's as sensing elements in gas chromatographic detectors. The effluent from the gas chromatograph was passed through a quartz tube heated to $800^{\circ} \mathrm{C}$ and pyrolyzed under hydrogen to yield hydrogen fluoride, hydrogen chloride, and hydrogen sulfide, as well as methane and water. The gases were absorbed in a flowing electrolyte, of which approximately one third passed beneath the surface of an ISE at a rate of $5 \mathrm{ml} / \mathrm{min}$ in a flow-through ce11. Small amounts of chloride 50 ymole and fluoride 1 pmole were

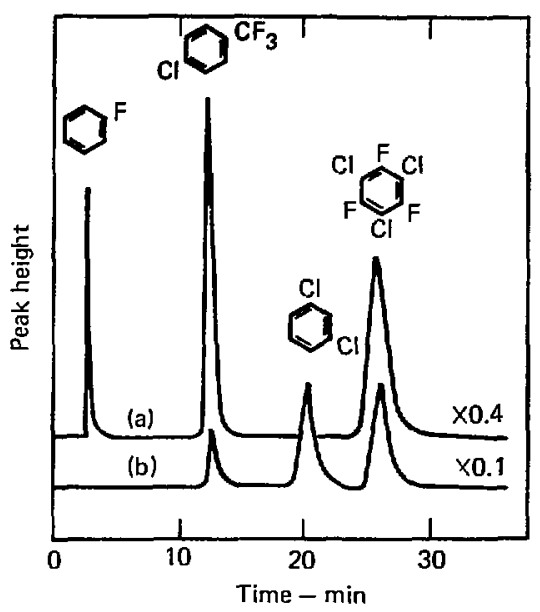

Fig. 36. Simultaneous selective detection of chlorine- and fluorinecontaining compounds by dual ionelectrode detector. (a) chromatogram of fluorine-containing compounds obtained from fluorine channel.

(b) Chromatogram of chlorinecontaining compounds obtained from chlorine channel. Source: Ref. 6, used with permission.

added to the absorbing solutions, along with $0.02 \mathrm{M}$ potassium nitrate to impart stability to the fluoride and chloride ISE's. The absorbing solution for sulfide contained $0.005 \mathrm{M}$ potassium carbonate and $0.01 \mathrm{M}$ potassium nitrate.

The electrical components consisted of a variable-resistance bucking device, a Keithley 610B voltmeterelectrometer, a voltage divider, and a variable-span recorder operated at 10 or $100 \mathrm{mV}$. The response time of the ISE's was concentration-dependent; 
Table 50. Response ratio $(\mathrm{Cl} / \mathrm{F})$ for compounds containing chlorine and fluorine.

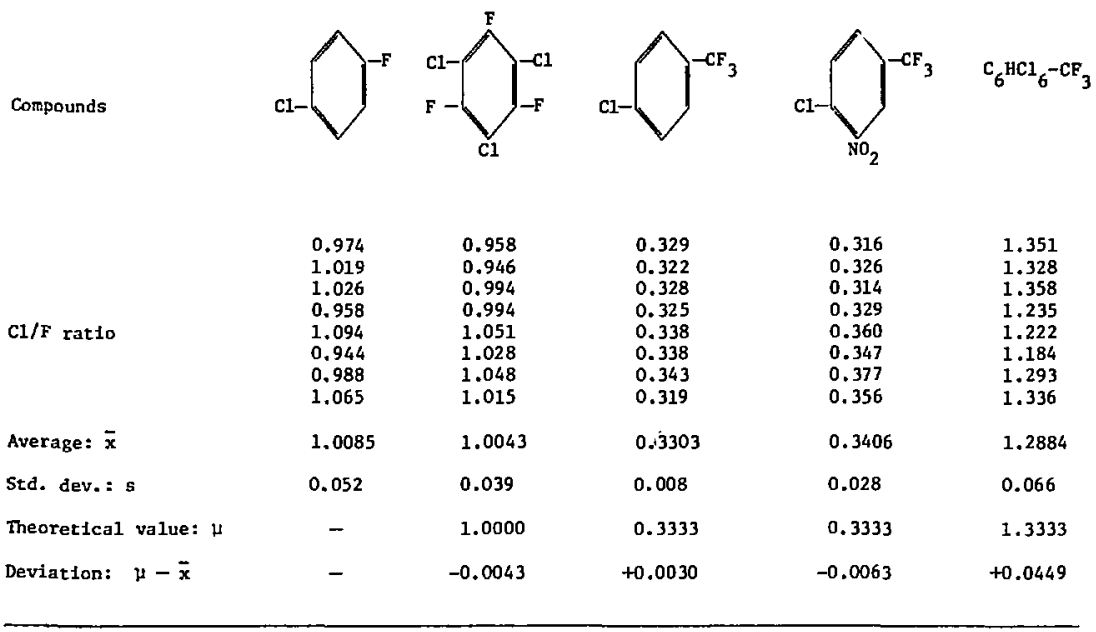

while it was nearly instantaneous for $10^{-4} M$ chloride, it was about 1 min for the same concentration of sulfide, and about 2 min for $10^{-4} \mathrm{M}$ fluoride. Raising the temperature of the solutions decreased the response time.

For the fluoride ISE, a linear relation existed between peak helght and amount added between $10^{-7}$ and $10^{-9} M$ sodium fluoride (the limft of detectability). The same Iimits existed for potassium chloride which, however, ylelded higher sensitivity, as shown by the slope of the calibration curve. For sodium sulfide, the Iimit of detectability was less than $10^{-10} \mathrm{M}$.

The response for some pesticides containing fluortne, chlorine, and sulfur is shown in Table 51. The sensitivity for trifluralin was poor, while that for the other two compounds was considerable better. As shown in FIg. 37, serious talling was observed in the fluorine- and sulfurcontaining compounds, but not in the compound containing chlorine. This qualitatively parallels the response times of the electrodes.

A mixture of $1 \mu \mathrm{g}$ each of methyl parathion, Ethion, and Guthion, containing one, four, and two sulfur atoms per molecule, respectively, was completely resolved within 30 min (FIg. 38), Talling was less notlceable, with the components havfng a longer retention time. A summary of some important parameters 
Table 51. Response of pesticides containing F, Cl and S.

Trifluralin

for the three ISE's is shown in Table 52. With the fluoride ISE there existed a 1000-fold differential between the detection limit for organic vs inorganic fluorine. This
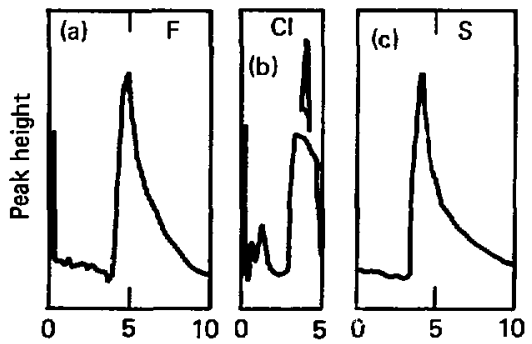

Time - min

Fig. 37. Peak shapes from injection of organic standards on GC. (a) $40 \mathrm{\mu g}$ trifluoroacetyl furadan; (b) $1 \mathrm{\mu g}$ heptachlor; and (c) $2.5 \mathrm{\mu g}$ methyl parathion. Glass $=36$ by 0.25 In.; Colum $=5 \%$ SE 30/Chromosorb G; GC oven $=180^{\circ} \mathrm{C}$; Pyrolysis oven $=800^{\circ} \mathrm{C}$; Carrier gas, $\mathrm{H}_{2}=$ $100 \mathrm{~m} 1 / \mathrm{min}$. Source: Ref. 8 , used with permission. may be due to poor combustion efficlency, adsorption of hydrogen fluoride prior to its reaching the electrode, or poor choice of the absorbing medium. A comparison of some Important parameters used by Kojima et $a$. and by Seiber with the fluoride ISE is presented in Table 53.

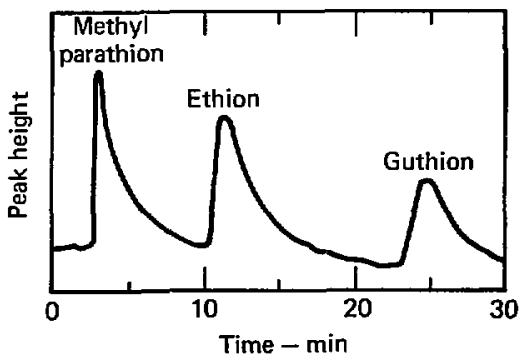

Fig. 38. Gas chromotograph of a mixture of $1 \mathrm{\mu g}$ each of Insect cide standards, sulfur mode (5\% SE 30 , $180^{\circ} \mathrm{C}$ ). Source: Ref. 8 , used with permission. 
Table 52. Summary of three modes of electrode detector.

\begin{tabular}{|c|c|c|c|c|}
\hline Pus & Electrolyte & $\begin{array}{l}\text { Detectable Ilmit } \\
\left.\text { (NaF, KC1, } \mathrm{Na}_{2} \mathrm{~S}\right)\end{array}$ & $\begin{array}{l}\text { Detectable limit } \\
\text { (organic } \mathrm{F}, \mathrm{C} 1, \mathrm{~s} \text { ) }\end{array}$ & $\begin{array}{r}\text { Tailing } \\
\text { factor }\end{array}$ \\
\hline$F$ & $\begin{array}{r}0.02 M_{\mathrm{KNO}_{3}}+ \\
10^{-6} \mathrm{MNa} \mathrm{F}\end{array}$ & $10 \mathrm{ng} \mathrm{F}$ & $3 \mu g$ & 10 \\
\hline CI & $\begin{array}{l}0.02 M \mathrm{KNO}_{3}+ \\
5 \times 10^{-5} M \mathrm{KCl}\end{array}$ & $36 \mathrm{ng} \mathrm{Cl}$ & $135 \mathrm{ng} \mathrm{C1}$ & 100 \\
\hline 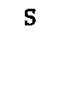 & 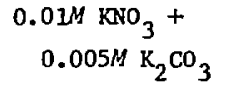 & $0.3 \mathrm{ng} \mathrm{s}$ & $1 \mathrm{ng} \mathrm{s}$ & 20 \\
\hline
\end{tabular}

${ }^{a}$ Salt solutions introduced directly into micromixer.

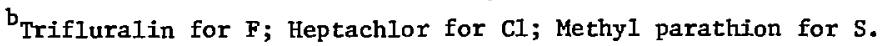

Seiber ${ }^{8}$ suggested several refinements for future work. Some of these already were used by Kojima ${ }^{2}$ :

- The use of oxidative, rather than reductive, pyrolysis would eliminate the interference from sulfide and armonia with the halide ISE.

- The use of postcombustion scrubbers might minimize $\mathrm{pH}$ interference and permit greater specificity for the elements of interest.
- The composition of the absorbing solution may be a critical factor in refining the electrode response; in particular, a buffered solution may be preferable.

Seiber also points out that it is possible to incorporate several ISE's into one basic system. The bromide and iodide ISE's have detection limits considerably below that for the chloride ISE and should detect

Table 53. Comparison of some parameters In GC detectors using the fluoride ISE.

\begin{tabular}{lll}
\hline Parameter & Kojima et al.. & \multicolumn{1}{c}{ Seiber $^{8}$} \\
\hline Method of combustion & $1000^{\circ}$, catalyst & $800^{\circ}$, no catalyst \\
Detector response at $10^{-4} \mathrm{M}$ & Several s & About $100 \mathrm{~s}$ \\
Heasuring cell, volume & $0.05 \mathrm{ml}$ & $0.01 \mathrm{ml}$ \\
Absorbing medium & $\mathrm{TISAB}$ & $0.02 \mathrm{M} \mathrm{KNO}$ \\
F $^{-}$addied to absorber & $10^{-5} \mathrm{M}$ & $10^{-6} \mathrm{M}$ \\
Absorber flow rate & $0.6 \mathrm{ml} / \mathrm{min}$ & $5 \mathrm{ml} / \mathrm{min}$ \\
\hline
\end{tabular}


compounds in concentration less than

$1 \mathrm{ng}$. The ammonia ISE has a detec-. tion limit near 1 mole, and could form a detector for a wide range of nitrogen-containing compounds.

\section{Liquid-Chromatography}

The material in this section is not specific to organic compounds, but seems of sufficient general interest to be included in this chapter. The preceding section dealt -ith ISE's used as detectors in gaschromatography. However, in every case the signal was generated in a liquid (the absorption solution) so that the ISE's served as IIquidchromatographic detectors.

Liteanu et ar. 9 have studied the posstbility of using a silver sulfide ceramic membrane electrode to determine the concentration of flowing electrolyte solutions. This electrode can be used as a liquid chromatographic potentiometric detector since it responds to all species, fnteracting chemically with silver or sulfide ions. The detector signal may be recorded without any changes by a high-input-impedance potentiometric recorder.

The Initial volume of the detector measuring cell was $450 \mu 1$; it was later reduced to $25 \mu 1$ to improve its sensitivity. It can be reduced by at least another order of magnitude without modifying its principle of construction. The carrier solution was $0.1 M$ potassium nitrate. The flow rate was $5 \mathrm{ml} / \mathrm{min}$. The electrode is simple, has good mechanical resistance, very Jow base nuise, and satisfactory reproducibility.

Schultz and Mathis ${ }^{10}$ have described a detection system for ion-exchange liquid chromatography at low to moderate pressures. A Varlan Model 4000 liquid chromatograph was used with a 2-by-50-mm stainless steel column packed with Zipax SAX pellicular anion exchange resin (DuPont). The electrode barre1 of a nitrate ISE (Orion 92-07) was fitted with a flow-through cap in which a small cavity was drilled to serve as detection chamber. The chromatographic column was connected to the ISE with polyethylene tubing, the dead volume of the connection was approximate1y $50 \mu 1$. The ISE and a silver/silver chloride reference electrode were immersed in a beaker containing the eluent solution. Pressures of $\leq 500$ psi at the column head were used without membrane rupture or entrapment of bubbles in the detection chamber. The ISE was sensitive to nmole amounts of inorganic and organic anions, and the principle can be extended also to cationic species. Figure 39 shows some chromatographic separations. 

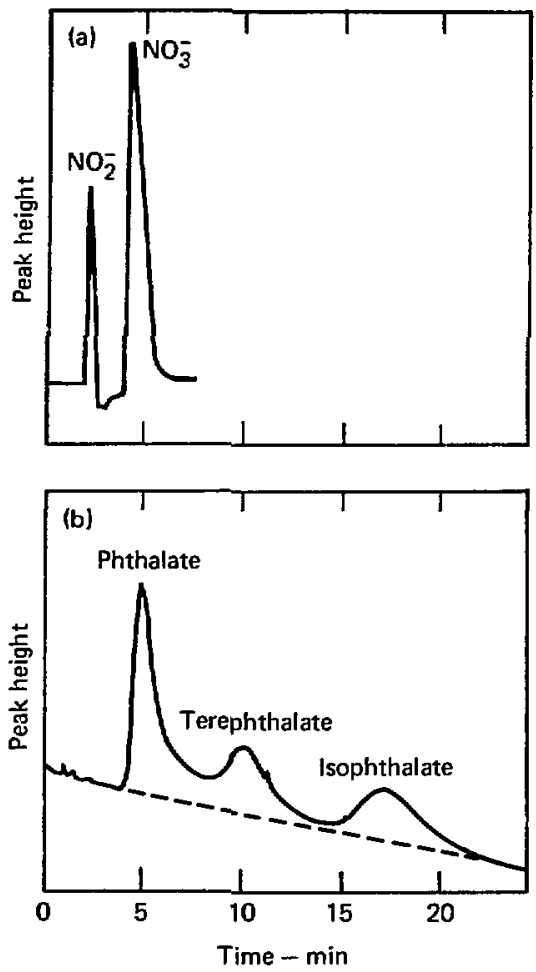

Fig. 39. Chromatographic separations: (a) Sample: $1.0 \mu 1,0.1 \mathrm{M} \mathrm{NO}_{3}^{-}$, $0.1 \mathrm{M} \mathrm{NO}=$; eluent: $0.01 F \mathrm{KH}_{2} \mathrm{PO}_{4}$, $0.01 \mathrm{~F} \mathrm{Na}_{2} \mathrm{SO}_{4}$, pH 7.0; flow rate $=$ $0.92 \mathrm{ml} / \mathrm{min}$; pressure $=375 \mathrm{psi}$. (b) Sample: $1.0 \mu 1,0.04 \mathrm{M}$ of each phthalate ion 1somer; other conditions as in (a). Source: Ref. 10, used with permission.

Even though the selectivity coefficient of nitrite at the nitrate ISE is only 0.04 , the detector response for the less selective nitrite fon was excellent. The separation shown for the three lsomeric phthalic actd isomers shows that the detector response to small amounts of relatively nonselective lons with the membrane in the ni:rate form is adequate.

Other species qualitatively separated and detected with this system include amino acld anions and sulfonic actd anions. One limitation of the liquid-membrane electrode detector is that highly selective anfons such as nitrate, perchlorate, and some halides must be excluded from the eluent. Because of their low selectivities, sulfate, phosphate, and borate salts are most suitable as buffers and/or eluents.

The detector response was linear from $1 \times 10^{-10}$ to $3 \times 10^{-7} M$ for nitrate, and for $3 \times 10^{-10}$ to $10^{-8} M$ nitrite, with a relative standard deviation of $\pm 3 \%$. Logarithmic calibration curves were based on the relation jetween anion content and the peak height obtained by recording the detector response. Peak areas can also be correlated empirically with the amount of sample.

The IIquid-membrane electrode detector should be useful in ionexchange chromatographic separations in which ultraviolet absorption or electrochemical activlty of the sample is poor or absent. By changing the composition of the Ifquid ionexchange solution, it is possible to obtain response to many organic and 
inorganic cations and anions and to enhance the selectivity for a selected group of lons.

Franks and Pullen ${ }^{11}$ have described a technique for the determination of trace amounts of halides in the presence of other ions. The mixed anions are separated by liquid chromatography on an ion exchange resin in the metal form. The detector system consisted of two silver/silver chloride electrodes, one was used as a reference, while the other was placed in the flowing stream. This permitted the determination of $\mathrm{ng}$ amounts of halide. Figure 40 shows the separation of chloride, bromide, and iodide in the presence of fluoride, sulfate, and nitrate.

By a suitable choice of eluting agent and stationary phase, it is possible to separate chloride from excess sulfide, to separate and determine chloride, bromide, and iodide, and to determine chloride $i$ boiler waters. The technique readily lends itself to automation and an apparatus for rapid, repetitive analyses has been destgned. The system has also been used to determine halogens in solutions resulting from SchönIger flask and Wickboldt apparatus combustions.

By using the cadnium acetate chromatographic system and a silver/ silver chloride electrode, thiosulfate and cyanide in the ppm region

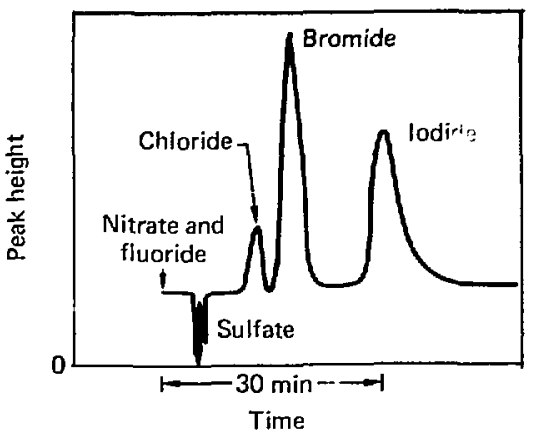

Fig. 40. Separation of chloride bromide, and fodide in presence of fluoride, sulfate, and nitrate. Stationary phase, Zeo-Karb 225, cadmium form; mobile phase, $0.0025 \mathrm{M}$ cadmium acetate, flow rate $=$ $0.4 \mathrm{ml} / \mathrm{min}$. Sample $50 \mu 1$, containing $1000 \mathrm{ppm}$ of sulfate, nitrate, and fluoride with $1 \mathrm{ppm}$ each of the other halides. Source: Ref. 11, used with permission.

were determined. With a chloride liquid-state ISE (Orion 92-17) as detector, nitrate and percnlorate in the ppm range were detected.

The combination of a lead amalgam electrode and cellulose-column chromatography has permitted the separation and determination of sulfate and phosphate ions. By means of a barium-sulfate-impregnated silicone-rubber electrode, trace amounts of sulfate and phosphate in solution were determined.

The authors state that there are many possibilities for devising other chromatographic-potentiometric systems. 


\section{References}

1. T. Kojima, M. Ichise, and Y. Seo, Bunseki Kagaku, 20, 20 (1971); cf. Chem. Abstr., 75, 58422d (1971).

2. T. Kojima, M. Ichise, and Y. Seo, Talanta, 19, 539 (1972).

3. T. Kojima, M. Ichise, and Y. Seo, Blinseki Kagaku, 22, 208 (1973); cf. Chem. Abstr., 79, 74739a (1973).

4. T. Kojima, Y. Seo, and J. Sato, Bunseki Kagaku, 23, 1389 (1974); cf. Chem. Abstr., 82, 149028r (1975).

5. T. Kojima, Y. Sea, and J. Sato, Bunseki Kagaku, 24, 772 (1975); cf. Chem. Abstr., 84, 144328v (1976).

6. T. KojIma, M. Ichise, and Y. Seo, Bunseki Kagaku, 24, 7 (1975); cf. Chem Abstr., 83, 21957w (1975).

7. E. A. Bramen and A. Dynako, AnaZ. Chem., 40, 95 (1968).

8. J. N. Seiber, presented at Eastern Analytical Symposium, Atlantic City, N. J., Fall 1972 .

9. C. Liteanu, I. C. Popescu, and H. Nascu, Rev. Roum. Chim., 17, 1615 (1972).

10. F. A. Schultz and D. E. Mathis, Anal. Chem., 46, 2253 (1974).

11. M. C. Franks and D. L. Pullen, Analyst, 99, 503 (1974).

\section{ACKNOWLEDGMENTS}

The author is indebted to the Department of Energy for a professional research and teaching leave, to the late Professor E. D. Bergmann of the Hebrew University of Jeru- salem for a research grant, and to Mrs. Miriam Goldstein and her staff for making his stay at the Hebrew University a $\mathrm{p}^{\urcorner}$asant one. 